\title{
The case of uneven development in Palestine: An investigation of scalar fix as an act of dispossession
}

\author{
Sandra Lange \\ West Virginia University
}

Follow this and additional works at: https://researchrepository.wvu.edu/etd

\section{Recommended Citation}

Lange, Sandra, "The case of uneven development in Palestine: An investigation of scalar fix as an act of dispossession" (2009). Graduate Theses, Dissertations, and Problem Reports. 4487.

https://researchrepository.wvu.edu/etd/4487

This Thesis is protected by copyright and/or related rights. It has been brought to you by the The Research Repository @ WVU with permission from the rights-holder(s). You are free to use this Thesis in any way that is permitted by the copyright and related rights legislation that applies to your use. For other uses you must obtain permission from the rights-holder(s) directly, unless additional rights are indicated by a Creative Commons license in the record and/ or on the work itself. This Thesis has been accepted for inclusion in WVU Graduate Theses, Dissertations, and Problem Reports collection by an authorized administrator of The Research Repository @ WVU. For more information, please contact researchrepository@mail.wvu.edu. 
The Case of Uneven Development in Palestine: An Investigation of Scalar Fix as an Act of Dispossession

\author{
Sandra Lange \\ Thesis submitted to the \\ Eberly College of Arts and Sciences \\ at West Virginia University \\ in partial fulfillment of the requirements for the degree of
}

\author{
Master of Arts \\ in \\ Geography \\ Graduate Committee \\ Dr. Robert Hanham, Ph.D (Chair) \\ Dr. Brent McCusker, Ph.D \\ Dr. Richard Hoch, Ph.D \\ Department of Geology and Geography \\ Morgantown, West Virginia \\ 2009
}

Keywords: Uneven Development, Dispossession, Scalar Fix, Israel, Palestine, Dialectics 


\title{
ABSTRACT \\ The Case of Uneven Development in Palestine: An Investigation of Scalar Fix as an Act of Dispossession
}

\begin{abstract}
Sandra Lange
Israel's assault on Gaza in December 2008 brought one of the world's most long-standing and hotly debated issues to the fore: the conflict between Israel and Palestine. Despite numerous diplomatic efforts to negotiate peace, the hostilities between the two parties continue. One of the fundamental obstacles to peace has been the highly uneven development between Israel and Palestine, caused primarily by Israel's continuous dispossession of Palestinian rights to land, water and sovereignty. In order to further our understanding of this phenomenon, this thesis sets out to examine processes of dispossession are carried out. The study therefore draws on the geographical concept of scalar fix and investigates how scalar fix consolidates power and functions as an act of dispossession of the Palestinian people. The analysis is based on a conceptual framework which utilizes Harvey's four key conditionalities of uneven geographical development as well as his matrix of multiple spaces. Linking the concept of scalar fix to the notion of dispossession, four types of scalar fix are identified and applied to the situation of Palestine. Dialectics is used as a methodology, both to develop the conceptual framework and to examine the case of dispossession in Palestine. The study finds that not only the formation of laws and treaties, but also the efforts of various networks, along with the control of knowledge and identity formation, constitute scalar fixes which facilitate Israel's consolidation of power and the act of dispossessing the people of Palestine.
\end{abstract}




\section{ACKNOWLEDGEMENTS}

I am greatly indebted to the following people and institutions, for this thesis would not have been completed without their continuous help and support. First, I wish to thank my graduate committee, primarily my advisor, Dr. Robert Hanham, whose knowledge, experience, passion and humor prepared and guided me to accomplish this work. His encouragement gave me the necessary confidence to face the challenge of delving into the realms of multiple spatialities and daring the 'dance of the dialectic'. He has been an excellent role model as a geographer and academic, as well as a person. I would also like to thank Dr. Brent McCusker for serving on my committee and for putting forward the critical questions essential for a sharp analysis. In addition, Dr. Richard Hoch deserves to be acknowledged for agreeing to devote his time and energy to my thesis at the last moment. Lastly, I wish to mention Alison Hanham whose support accompanied me for the major part of my thesis. My thoughts are with her and I wish her all the best for the future.

I also want to thank the graduate students as well as the members of staff and faculty at the Department of Geology and Geography, who have contributed to the making of this thesis in various ways. Among the many students who have assisted me over the past two years, I wish to recognize Denyse Wyskup for sharing her literature on dialectics, space and place, and for providing useful input into the use of dialectics. I am also greatly indebted to Joshua Wixom and Amy Riegner: Thank you for being such great office mates and for showing so much patience. Thanks are also due to Dr. Amy Hessl and Randy Crowe, who have made it possible for me to complete my Master's degree while being abroad.

In addition, I wish to express my gratitude to the staff at the Islamic Foundation in Markfield, UK. Among many, Humeyra Ceylan deserves to be recognized for providing me access to the vast resources at the Islamic Foundation Library and supporting me with my research and writing while away from WVU. I am also grateful to the staff at the Markfield Institute of Higher Education, who assisted me with the technical facilities to present my thesis while being in England.

Finally, I am greatly indebted to my family; first and foremost my dear parents, without whose continuous moral support it would have been very difficult to complete this thesis. I also wish to thank my grandparents, my aunt Marion and her husband, Oswald, for their encouragement and financial assistance which enabled me to study abroad. Last, but not least, I wish to recognize Eizeddin: Thank you for all your patience and understanding, for sharing your view from an Arab perspective, and for staying up late to help me edit and format my thesis. Thank you for being such a loving and caring husband. Jazakum Allahu khairan. 
TABLE OF CONTENTS

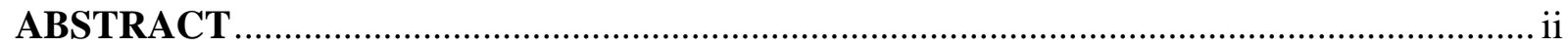

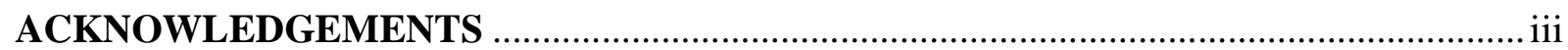

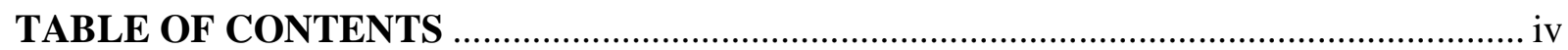

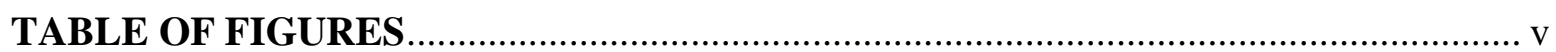

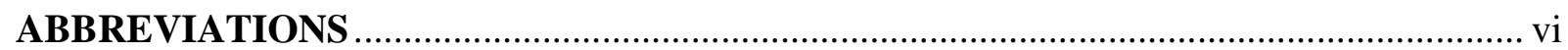

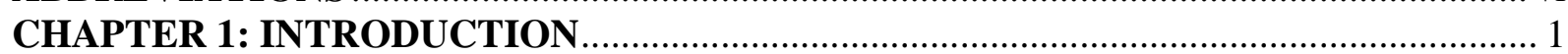

CHAPTER 2: DIALECTICS AS METHODOLOGY

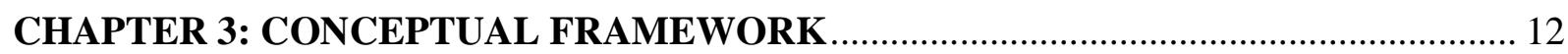

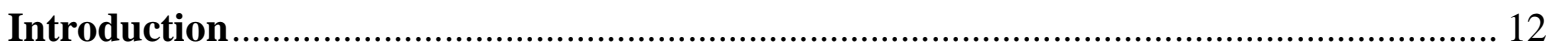

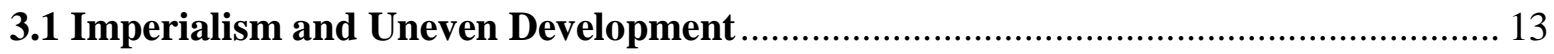

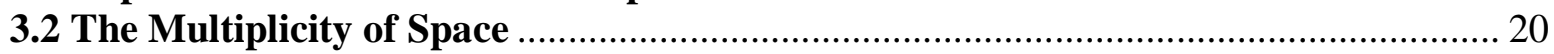

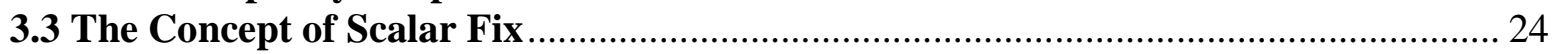

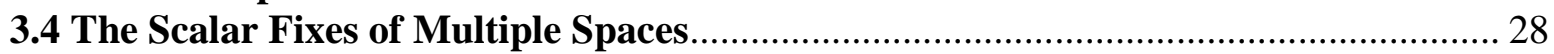

CHAPTER 4: CONSOLIDATION OF POWER THROUGH LEGISLATION AND

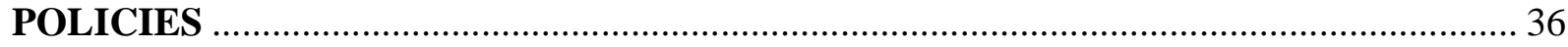

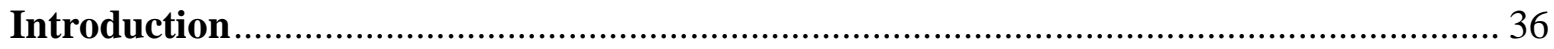

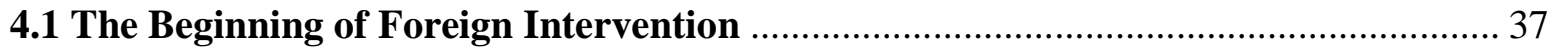

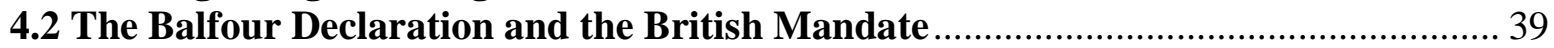

4.3 The Plan for Ethnic Cleansing and the Establishment of the State of Israel ............. 44

4.4 Judaization and the Consolidation of Territorial Boundaries.................................... 50

4.5 The Military Administration in the Occupied Territories After 1967 ..................... 55

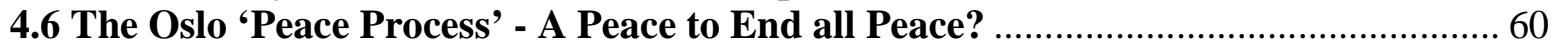

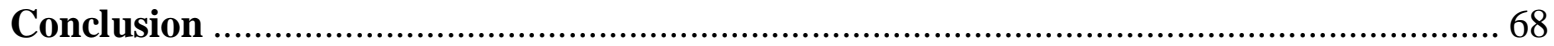

CHAPTER 5: CONSOLIDATION OF POWER THROUGH NETWORKING ................. 70

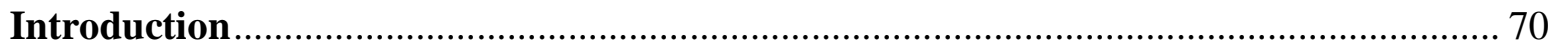

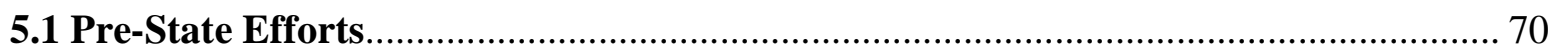

5.2 The "Special Relationship" Between the US and Israel ........................................... 75

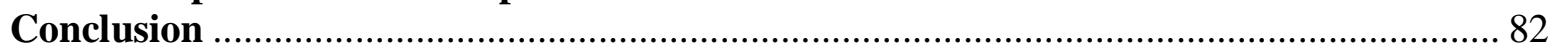

CHAPTER 6: CONSOLIDATING SPATIAL REPRESENTATION - SCALING

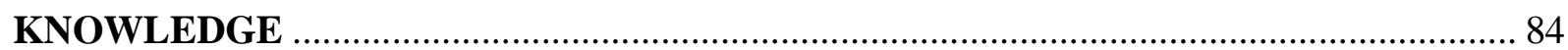

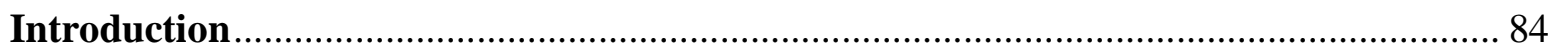

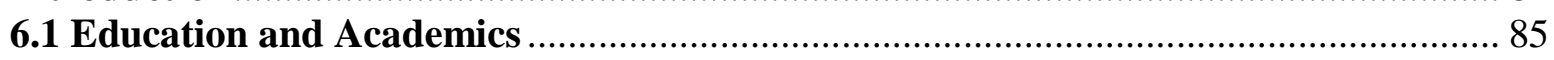

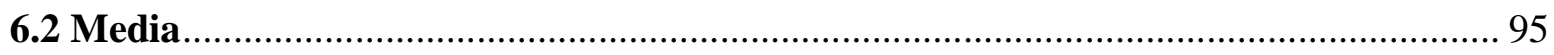

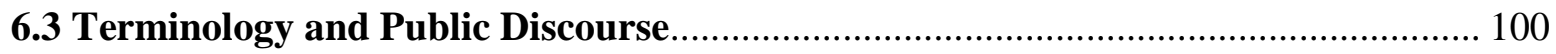

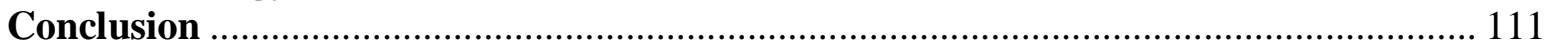

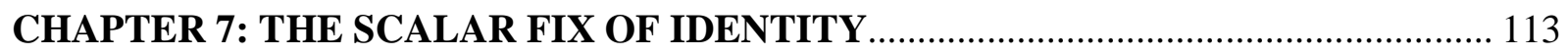

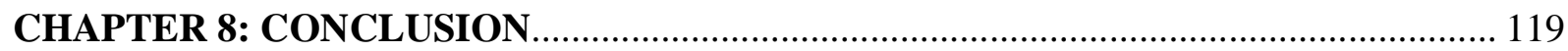

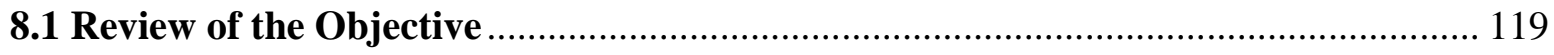

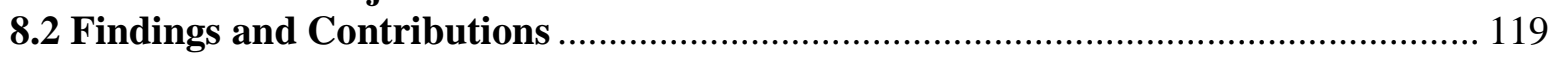

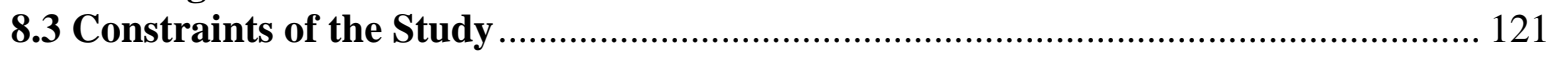

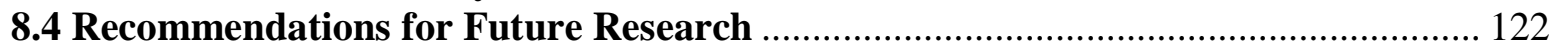

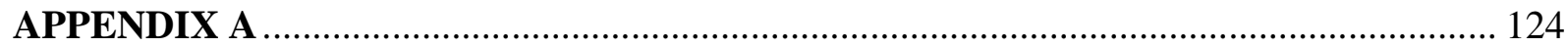

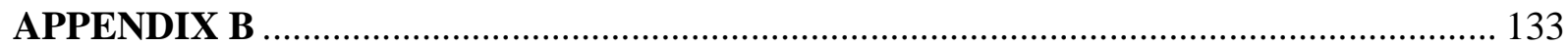

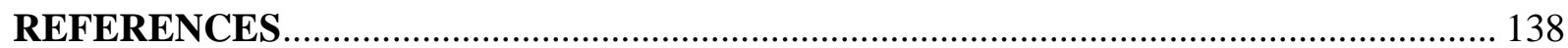




\section{TABLE OF FIGURES}

Figure 1: Distribution of the Palestinian People Worldwide ...................................................... 3

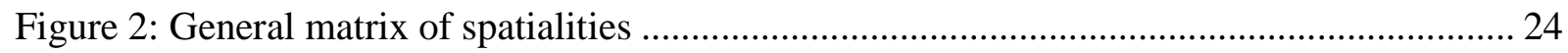

Figure 3: Landownership in Palestine and the UN Partition Plan, 1947 ..................................... 46

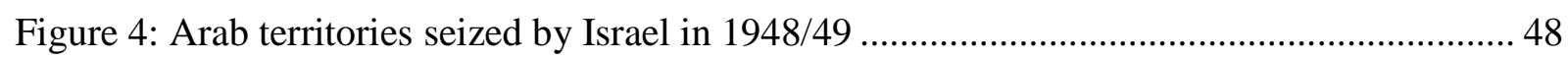

Figure 5: Growth of the settler population, excl. East Jerusalem ............................................. 53

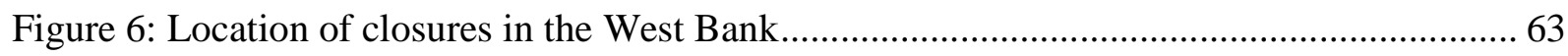

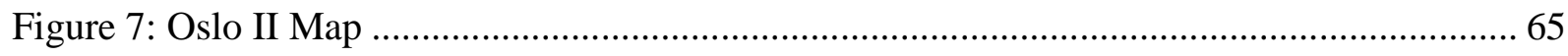

Figure 8: Plan of the Peel Commission, 1937 in comparison to the UN Partition Plan, 1947 .... 74 


\section{LIST OF ABBREVIATIONS}

\begin{tabular}{|c|c|}
\hline AIPAC & Israel Public Affairs Committee \\
\hline AP & Associated Press \\
\hline CIA & Central Intelligence Agency \\
\hline CIPM & Center for Monitoring the Impact of Peace \\
\hline CPMAJO & Conference of Presidents of the Major American Jewish Organizations \\
\hline DP & Displaced Persons \\
\hline EU & European Union \\
\hline GSS & General Secret Service \\
\hline IDF & Israel Defense Forces \\
\hline IMF & International Monetary Fond \\
\hline JOPS & Journal of Palestine Studies \\
\hline MO & Military Order \\
\hline OT & Occupied Territories \\
\hline PA & Palestinian National Authority \\
\hline PASSIA & Palestinian Academic Society for the Study of International Affairs \\
\hline PLO & Palestine Liberation Organization \\
\hline PNAC & Project for the New American Century \\
\hline UK & United Kingdom \\
\hline UN & United Nations \\
\hline UNGA & United Nations General Assembly \\
\hline UNOCHA & United Nations Office for the Coordination of Humanitarian Affairs \\
\hline UNRWA & United Nations Relief and Works Agency for Palestine Refugees in the Near East \\
\hline UNSCOP & United Nations Special Committee on Palestine \\
\hline US & United States \\
\hline WA & Welfare Association \\
\hline WWI & First World War \\
\hline WWII & Second World War \\
\hline $\mathrm{ZPC}$ & Zionist Power Configuration \\
\hline
\end{tabular}




\section{CHAPTER 1: INTRODUCTION}

"Israel distinguished the war against terror... against Hamas...and in doing so, we keep the situation in Gaza strip completely as it should be." Tzipi Livni

The events of the recent months have, once again, brought one of the world's most longstanding and hotly debated conflicts to the fore: the conflict between Israel and Palestine. Throughout the 22 days of Israel's assault on Gaza, ${ }^{1}$ the above statement by then Israeli foreign minister Tzipi Livni was repeated again and again on Al Jazeera's English news channel, becoming ingrained into the viewer's mind. As the figures of Palestinian casualties rose into the thousands, one could not help but wonder about the meaning of Livni's announcement. Did she refer to the familiar 'purity of arms' doctrine, implying that civilians were not affected (unless they had the nerve to accommodate 'terrorists' among their families)? Or did she indeed suggest that the situation of utter chaos and destruction, robbing the Palestinians in Gaza of whatever little means they had left to sustain their livelihood after 18 months of economic blockade, is how life for the Palestinians "should be"?

Either way, the statement reflects very well the position of both the Israelis and the Palestinians, which seems to have changed little since the beginning of this longstanding conflict. Public opinion of the two parties appears to remain as it was: Israel, in it's everlasting search for 'peace' and 'security' makes use of its right to defend its population against the 'terrorists' who threaten the existence of the Zionist state - by throwing stones and firing homemade rockets.

Based on this commonly accepted imagery, the world sat on their hands watching Israel's bombardment of Gaza's population, which had been suffering from an 18-months economic

\footnotetext{
${ }^{1}$ The war lasted from 27 December 2008 till 18 January 2009.
} 
blockade, without any serious attempts of intervention. While emergency meetings and summits were called to negotiate an end to the war, all diplomatic efforts remained without success. Even a UN Security Council resolution - proudly presented after tedious negotiation processes calling on both parties to cease fire immediately went unheeded. Furthermore, despite the verbal denunciation of Israel's relentless attacks on defenseless civilians by US and European leaders, the deliberate bombardment of humanitarian shelters organized by UNRWA (United Nations Relief and Works Agency for Palestine Refugees in the Near East), as well as other war crimes involving the usage of illegal materials such as white phosphorus, went largely unpunished. Instead, the blame was laid on the Gazans themselves for supporting Hamas, a resistance movement considered a terrorist organization.

This most recent assault on the Palestinian people is not a one-time occurrence, but rather a continuation of a long-standing conflict with no end in sight. After a century of hostility and violence between the two people concerned, after considerable amounts of scholarship and writing aimed to bring understanding to the issue, and, most notably, after tireless efforts of conflict resolution and peace negotiations, the situation in the land of Palestine seems to increasingly worsen rather than showing any improvement. Whereas Israel developed over the centuries into one of the world's most developed states, the living conditions of the Palestinians have been, and remain, rather appalling. Moreover, while Israelis live within the internationally recognized borders of a sovereign state, the people of Palestine are spread over a range of countries. Figure 1 shows the distribution of Palestinians worldwide, highlighting that almost half the total population lives outside their homeland of Palestine. The majority of those in exile, some 4.6 million live in the 58 refugee camps operated by UNRWA in the Middle East. ${ }^{2}$

\footnotetext{
${ }^{2}$ This is the official figure of the refugees registered with UNRWA. It should be noted that the actual number is likely to be even higher, as many refugees are not officially registered.
} 


\begin{tabular}{|c|c|c|c|c|c|}
\hline Inside & & Outside & $\mathrm{I}^{2}$ & $\mathrm{II}^{3}$ & III $^{4}$ \\
\hline \multirow{6}{*}{$\begin{array}{l}\text { West Bank \& } \\
\text { Gaza Strip }\end{array}$} & \multirow{7}{*}{$4,016,416$} & Jordan & $2,839,639$ & $2,472,501$ & $2,626,000$ \\
\hline & & Lebanon & 421,292 & 456,824 & 463,000 \\
\hline & & Syria & 422,699 & 494,501 & 411,000 \\
\hline & & Egypt & 62,846 & 51,805 & 48,000 \\
\hline & & Saudi Arabia & 314,226 & 291,778 & 299,000 \\
\hline & & Kuwait \& other Gulf & 166,086 & 149,786 & 135,000 \\
\hline \multirow{4}{*}{$\begin{array}{c}\text { Areas } \\
\text { Occupied in } \\
1948^{1 b}\end{array}$} & & Libya and Iraq & 117,276 & 78,884 & 79,000 \\
\hline & & Other Arab countries & 6,621 & 5,887 & - \\
\hline & $1,416,300$ & The Americas & (USA:) 238,721 & 216,196 & - \\
\hline & & Other Countries & 303,987 & 275,303 & 606,000 \\
\hline Total Inside & $5,432,716$ & Total Outside & $4,913,393$ & $4,493,465$ & $4,667,000$ \\
\hline
\end{tabular}

${ }^{14}$ PCBS, Demographic Statistics, figures for $2007 \quad{ }^{1 b}$ Israeli CBS, figures for 2006. ${ }^{2}$ PCBS, Mid-year 2004 estimates, Statistical Abstract no, 6, 2005.

3 Salman Abu Sitta. Palestine 1948 - Commemoration of A/-Nagba. London: Palestinian Retum Center, May 2000.

"Justin McCarthy. "Population", entry in Encyclopedia of the Palestinians, ed. by Philip Mattar. New York, 2000.

Figure 1: Distribution of the Palestinian People Worldwide. (Source: PASSIA)

This thesis aims to examine one of the key components of the overall conflict - the perpetual, all encompassing dispossession of the Palestinian people and the resultant uneven development between the two people who seek to lay claim to the land of Palestine. While much has been written on specific spatio-temporal aspects of this seemingly unsolvable issue, I hope to analyze some of the underlying processes, therein furthering our understanding of the overall conflict. I will do this by viewing the conflict from a geopolitical angle, utilizing a dialectical approach to knowledge and applying a theoretical framework that incorporates the geographical concept of scalar fix into the theory of uneven development as defined by Harvey. ${ }^{3}$

The two specific objectives of the thesis are therefore defined as follows:

i. To develop a conceptual framework that links scalar fix to Harvey's four key conditionalities of uneven development, in particular the process of accumulation by dispossession.

ii. To investigate the use of scalar fix as a deliberate function of the socio-economic dispossession of the Palestinian people.

\footnotetext{
${ }^{3}$ Harvey, D. (2006). Spaces of Global Capitalism: Towards a Theory of Uneven Geographical Development. Verso: New York.
} 
In the academic field of geography, the concept of scale reflects, generally speaking, the geographical structure of social interaction in space, whereby space is not merely understood as physical and absolute but moreover incorporates relational and social spatialities. ${ }^{4}$ Smith describes the production and consolidation of scale - the scalar fix - as a way of geographically organizing and expressing collective social action. ${ }^{5}$ In other words, scalar fix is by no means accidental, but describes the premeditated setting of boundaries which provide the territorial framework for political, economic and cultural processes within a society. It thus becomes a powerful tool for dominant powers to steer these processes according to their own interests, and to accumulate and consolidate financial and military power at the expense of weaker elements of society. In that sense, the thesis argues that the concept of scalar fix is closely related to uneven geographical development and what Harvey refers to as "capitalist imperialism". 6

The thesis is divided into 8 chapters. Chapter 2 addresses the study's methodology dialectics - which is applied both to the theoretical framework and the following analysis of the case of dispossessing the Palestinian people. The general overview of dialectics provided in the second chapter is based on Ollman's analysis of the way the dialectical method was used by Marx to study capitalism as the dominant mode of production and social system. As the subject of this study is in many ways a product of capitalist-imperialist aspirations, the use of the dialectical approach is imperative, for according to Ollman, dialectics is "the only sensible way to study a world composed of mutually dependent processes in constant evolution."7

\footnotetext{
${ }^{4}$ Ibid.

${ }^{5}$ Smith, N. (1995). Remaking Scale: Competition and Cooperation in Pre-national and Post-national Europe. In Heikki, Eskelinew, Folke and Snickars (Eds.) Competitive European Peripheries. (pp. 59-74). New York: Springer, p.61.

${ }^{6}$ Harvey, D. (2003). The New Imperialism. Oxford: Oxford University Press, p. 26.

${ }^{7}$ Ollman, B. (2003). Dance of the Dialectic: Steps in Marx's Method. Urbana/Chicago: University of Illinois Press, p. 158.
} 
Chapter 3 lays out the theory which provides the conceptual framework for an analysis of the uneven geographical development that defines the Palestine-Israeli conflict. The theoretical approach draws on David Harvey's thesis that uneven geographical development is primarily achieved through the accumulation of capital by dispossession. It further utilizes the geographical concepts of spatial and scalar fix, both of which are not applied only to absolute space but are associated with the multiple spatialities defined by Harvey and Lefebvre. Finally, I attempt to link these two components by arguing that scalar fix is used as an act of dispossession leading to further uneven development.

Chapters 4 to 7 constitute the analysis part of this thesis, i.e. an examination of the usage of various types of scalar fix as acts of dispossessing the Palestinian people of their political and civil rights, livelihood, and identity. The themes of each chapter range from rather concrete issues of policy making to more abstract ideologies of identity and difference. Chapter 4 examines the scalar fix of legislation and treaties which, in their function of consolidating the power of Zionist rule in Palestine, have largely determined the course of events. In that sense, chapter 4 provides a rough timeline of the Palestine-Israeli conflict. This is followed, in chapter 5 , by an analysis of the effect of networking, which is closely interrelated with the adoption of laws and treaties, for the networking relationships are oftentimes key in the formation of legislation.

Chapter 6 investigates the use of scalar fix to control knowledge, which is understood as an essential tool to organize and manipulate the spatial representation of the Palestinian people and the Palestine-Israeli conflict overall. Taking into consideration the multiple channels available for the production and dissemination of knowledge, this chapter includes the fields of education, media, and public discourse and shows how they are utilized to dispossess 
Palestinians not only of their physical means of livelihood, but also of the basic rights to define themselves as Palestinian people. On a yet higher level of abstraction, chapter 7 examines the scalar fix of identity and how the notion of different identities - constructed primarily through the scalar fix described in chapter 6 - is utilized to claim superiority of one social structure over the other, thus providing a legitimization for the dispossession of the Palestinians on the most fundamental level.

\section{CHAPTER 2: DIALECTICS AS METHODOLOGY}

The application of dialectics as methodology in this thesis is grounded in the work by Bertell Ollman, Dance of the Dialectic. Dialectics, as laid out by Ollman, is the Marxist method used to study ongoing processes which cause changes within a social structure, by starting from the system as a whole and breaking it down into individual components, or social factors. Contrary to common methodology in social sciences, dialectical examination of these factors sets out from a relational perspective. Thus, the main purpose of isolating a social factor is to draw conclusions in relation to the entire system. In other words, social factors or units of a society are not treated as independent or at best externally related, but are understood as internally related, in a sense that the relation itself is seen as a significant part of each unit. These Relations ${ }^{8}$ are defined by the processes and flows associated with them. Recognizing this interdependence of all the parts making up the structure as a whole, dialectics takes "account of the changes and openendedness that constitute so large a part of social life." ${ }^{9}$ Every factor is also internally related to its past and future, as well as to past and future forms of other social relations. A book, for instance, is contained in the pages that were used to bind it, as well as in the wood that was cut in

\footnotetext{
${ }^{8}$ Ollman capitalized the word in order to distinguish from "relation" in the sense of "connection".

${ }^{9}$ Ollman, op. cit., p. 26.
} 
order to produce the paper in the first place. But the book is also all the thoughts, knowledge and experiences that went into its writing, as well as the struggles with the publisher who insisted on censoring critical parts of the story.

Rather than looking at concrete matter and the external relations of things, it is the flow of internal processes of a given structure which dialectics seeks to examine in order to understand how and why structural change occurs within a system. Focus is thus placed on the historical transformation of the internal relations of social structures. This view also goes beyond defining a commonly known causal relationship where one factor may be identified as cause and others as conditions. Rather, "cause" and "condition" are internally related parts of each other. Changes occur not simply because one factor changes, but rather it is the relation that changes, thus - through its internal connectedness with everything else - directly or indirectly changing the whole.

Marx identified four types of Relations: identity/difference, interpenetration of opposites, quantity/quality, and contradiction. When conceptualizing things as Relations, a specific phenomenon may appear identical in one sense, but convey a difference if studied at a more detailed level. Although the Palestinian Arabs clearly share an identity as a nation, there are different loyalties according to religion, class or belonging to a city or region. At larger scale, there is an Arab identity spread through out the region of South-West Asia, yet differences are evident between Egyptian and Syrian Arabs.

The interpenetration of opposites is based on the assumption that surrounding conditions treated as internal relations determine the appearance and function of objects and the people who perceive them. ${ }^{10}$ Ollman emphasizes the 'perspectival element' involved: While the separation wall along the West Bank is considered by the Israeli government as a necessity to maintain

\footnotetext{
${ }^{10}$ Ibid., p. 16.
} 
security, the barrier constitutes an essential threat to the livelihood of the Palestinian Arabs whose farm land is confiscated and rendered useless due to the construction project. Although these different perspectives do not imply equal truths they help us gain understanding in that they present oppositional perspectives revealing the impact of a given situation.

The quantity/quality relation helps us understand how change occurs in looking at the 'before and after' aspects of the development of a situation. A distinction between quantity and quality shows that change may become apparent only after taking a qualitative form, yet one must be aware that - quantitatively - this change may come about at a much earlier stage. Therefore, the underlying processes must be looked for in both qualitative manifestation, but also the preceding mechanisms as causal factors for change. The build-up of Jewish settlements starts out as a quantitative change with few housing arrangements scattered seemingly arbitrarily throughout the country. It is the increasing number of settlements over time which eventually leads to the qualitative creation of 'facts on the ground' designed to legitimize the Jewish state of Israel.

The most significant relation identified by Marx is contradiction, which Ollman defined as the "incompatible development of different elements within the same relation [...] between elements that are also dependent on one another." The differences between these elements are based on certain conditions which are constantly changing, thus generating a transformation in the differential elements themselves. To the extent that each element is part of a whole, one change in a condition will affect the entire structure. It is hence the focus on the contradictions within a Relation that allows us to recognize how change is produced and how it might affect development in the future. There is a great contradiction, for example, between Israel's official 
quest for 'peace and security' with its Arab neighbors and its simultaneous expansion of Jewish settlements in the West Bank, Gaza and the Golan Heights.

In his dialectical approach of breaking up the whole into interrelated parts, Marx utilized three levels of abstraction: extension, level of generality and vantage point. Operating in these different modes provides three different kinds of focus on the important aspects of a certain phenomenon we wish to study. ${ }^{11}$ Extension refers to the spatial and temporal boundaries set for the structure which is to be abstracted. This allows the analysis of a specific problem to be carried out not only within a certain historical time frame but also a defined spatial territory. Thus, in order to study the Israel/Palestine conflict, our temporal extension reaches back to the creation of the Zionist movement in the 1880s, while the main spatial focus is set on the contested land of Palestine. These boundaries, however, are not fixed but rather dialectically manipulated, in order to identify the true extent of a relation. In the case of Palestine this requires a spatial extension to include the neighboring Arab states as well as the British and US powers and investigate their role in shaping Palestinian space.

The abstraction of extension is related to the second mode of abstraction, the level of generality. This involves the move of viewing a relation in its narrower, concrete sense toward a more general, more abstract understanding: from the individual level to that of human society as a whole. The closer one stays to the concrete world, the lower the level of abstraction. When abstracting the economic situation of Palestinian Arabs, we find at a lower level the concrete situation of the individual Palestinian who is forced to work for Israeli construction companies, building Jewish settlements in place of where his own house was torn down after Israeli legislation having rendered it illegal. At a higher level we may look at the Arab labor force in general, which is exploited by Israeli capitalists. Ollman points out that, in order to study a

\footnotetext{
${ }^{11}$ Ibid., p. 175.
} 
particular Relation, it is essential to choose that level of generality which highlights the characteristics responsible for shaping a problem. ${ }^{12}$ If we want to explain foreign support for the Zionist movement, it is necessary to focus on a more concrete level of the individual to analyze and evaluate the role of personalities such as Lord Rothschild. At the same time, we must consider Zionism as a whole on a more general level in order to understand the entirety of its impact on Palestinian space.

The third mode of abstraction is the vantage point, which is established in correspondence to the abstraction of extension and level of generality at which a given problem is studied. As researchers face the risk to study a phenomenon under the influence of their own perspective (or that handed down by their own culture), the focus on a specific level of generality, at a given spatio-temporal extension, allows identifying the precise angle from which the problem should be investigated.

Using the dialectical method of abstracting a given situation from the concrete allows us to study phenomena as complex as the Palestine-Israeli conflict. As all objects and events are treated as internally related, dialectics will help identify the contradictions and tensions which cause social contest and thus bring about change. The three modes of abstraction further aid in setting the correct focus on the causal relations and thus lead us to an understanding of the outcomes of social struggle.

Through its method of abstracting those patterns of a given system most associated with interaction and change, dialectics has the potential to draw conclusions necessary to recognize the bigger picture which is often lost in analysis of a social problem studied in isolation. As Ollman pointed out, dialectics attempts to study "those who steal the commons from under the

\footnotetext{
${ }^{12}$ Ibid., p. 90.
} 
goose" rather than focusing on "the people who steal a goose from off the commons." ${ }^{13}$ While this approach is essential to any study of capitalist-imperial forces and uneven development, it is particularly suited for an analysis of the Palestine-Israeli conflict.

Previous works in geography show that dialectics is not only used conceptually, but can also be applied to a concrete situation. Using dialectics, Merrifield's 'reconciliation' of Lefebvre's "Place and Space" offers a conceptualization of the capitalist space-place relationship. Merrifield then applies his interpretation of the politics of space to the case of "Redeveloping American Can in Southeast Baltimore". Similarly, I will use dialectics to pursue my two specific objectives: to further develop the concept of scalar fix and to gain understanding of the development of Palestine as a case in the concrete world. While data for the dialectical method may be obtained from both primary and secondary sources, my research will focus on secondary sources including written material and research done by others, statistical and census data.

\footnotetext{
${ }^{13}$ Ibid., p. 155.
} 


\section{CHAPTER 3: CONCEPTUAL FRAMEWORK}

\section{Introduction}

For a fruitful analysis of the function of accumulation processes as a key ingredient of uneven geographical development, and its linkage to processes of everyday life and the perpetual social struggle to resist dominant forces, we need to understand various geopolitical concepts. The first section of this chapter addresses the role of imperialism, first in form of the British Empire and later under US hegemony, and its connection to uneven geographical development and its individual components.

The second part defines the multiple concepts of space and how they will be used for dialectical analysis. By encompassing multiple spatialities as described by Harvey, ${ }^{14}$ I hope to identify and focus on those underlying processes and internal socio-spatial relations which may help analyze and understand the social phenomena and struggles we encounter in everyday life, and which constitute potential agents of change. It is hence important to recognize space not merely as extant in the physical realm, but as a social construct tightly interwoven with the mode of production as well as other social relations. This focus on social space is insofar essential, as it is in this realm "where the dominant relations of production are reproduced."15 As the processes of the capitalist mode of production are part of our everyday, social life, they play a significant role in shaping and structuring the spatial environment. Thus in order to understand this impact on space, we have to look at the system as a whole while singling out the relevant individual relations.

\footnotetext{
${ }^{14}$ Harvey, Uneven Development, op. cit.

${ }^{15}$ Soja, E. (1980). The socio-spatial dialectic. Annals of the Association of American Geographers, 70 (2), p. 213.
} 
The spatial fix, first identified by Harvey is a key concept in understanding how capital is accumulated, and, more importantly, how accumulation crises evolve and affect the geographical space. In the third part of this chapter I will take a short step from the spatial fix towards the concepts of scale and scalar fix, which, I argue, may be linked to the processes of capital accumulation, in particular through devaluation and dispossession. As the impact of these accumulation processes spans over a variety of social spatialities beyond the world of the concrete, the scalar fix should be applied to these multiple spatialities.

\subsection{Imperialism and Uneven Development}

In tackling the social impact of capitalism from a geographical perspective, we need to look at the expansionary policies of imperialism and the resultant spread of uneven development. Yet, in order to enable a meaningful analysis, it is imperative to have a clear understanding of the meaning of these terms. Imperialism is, broadly defined, "an extension or imposition of the power, authority or influence of a state over other states, or stateless communities." ${ }^{16}$ In this sense, imperialism has been extant for a long time. The rise of capitalism as the dominant mode of production, however, formed a new type of 'capitalist imperialism. ${ }^{, 17}$

Under the expansion of capitalist imperialism we recognize two forces at work: the 'territorial' and 'capitalist' logics of power. ${ }^{18}$ The territorial logic refers to the diplomatic and, more significantly, the military means of a state to exercise and expand its power. On the contrary, the capitalist logic constitutes the flows of economic power "across and through continuous space ... through the daily practices of production, trade, commerce, capital flows,

\footnotetext{
${ }^{16}$ Arrighi, G. (2005, March/April). Hegemony Unravelling -1. New Left Review, 32, p. 27.

${ }^{17}$ Harvey, New Imperialism, op. cit., p. 26.

${ }^{18}$ See both Arrighi and Harvey.
} 
money transfers..." ${ }^{19}$ Harvey emphasizes that the relation between these two inherently distinct logics of power is not always straightforward, but rather complex and contradictory in a dialectical sense. ${ }^{20}$ Hence, in order to analyze imperialist moves, it is necessary to look at the interrelation of these two components, as both have been used throughout the historical geography of capitalism and the pursuit and accumulation of power.

Whereas the capitalist-imperialist expansion was, at its outset, dominated by city states such as Venice, Genoa and Amsterdam, they were eventually replaced by territorial states, the latter being more powerful key players. From the formation and consolidation process of nationstates which took place in Europe throughout the $18^{\text {th }}$ and $19^{\text {th }}$ century, the United Kingdom emerged as the key player. Under the pretense of acting in the general interest of the newly consolidated 'Concert of Europe', the British Empire established unprecedented world power. ${ }^{21}$

Under the cloak of being the beneficiary Britain's imperial strife for power was acted out in the open, consolidating British authority and influence over major parts of the world. The contrary has been the case with its successor, the United States, the hegemony of which deserves some more detailed attention. Since the beginning of its domination with the end of WWII, America has hidden its imperial ambitions under a rhetoric designed to divert from numerous involvements in foreign affairs. Yet an interventionist foreign policy has materialized using both the capitalist as well as the territorial logic of power. Rather than talking of an American 'Empire' the focus has been placed on the emergence of the 'American Century', thus drawing off the attention from expansionist efforts and implying that it is America's 'turn' of world leadership. For the past six decades, America has exercised its influence through actions of a

\footnotetext{
${ }^{19}$ Harvey, New Imperialism, op. cit., pp. 26/7.

${ }^{20}$ Ibid., p. 30.

${ }^{21}$ For an excellent account on the 'cycles of accumulation' see Arrighi, G. (2005, May). Hegemony Unravelling - 2. New Left Review, 33, 83 - 116.
} 
rather covert and subtle nature, ranging from CIA aided forced regime changes in geopolitically significant countries, to taking leadership of supranational governmental organizations such as the UN, World Bank and IMF. ${ }^{22}$

A significant change in policy was taken in the 1970s, when the U.S. leadership started to follow a neo-liberal paradigm which emphasized finance capital over productive activity. Domestically, the privatization of sectors beneficial to the whole society, such as transportation and electricity, took place at the expense of the individual's rights. On the global level, capital investment in the underdeveloped world - guided and aided by the World Bank's structural adjustment programs - forced developing countries to design their governmental and financial structure in accordance with the capitalist system of the 'advanced' world. ${ }^{23}$ In this sense, it is important to recognize the role played by development policies, assistance programs and aid as part of an imperialist global outreach. This way of promoting the neo-liberal economic model has been coined as 'financial low intensity warfare'. ${ }^{24}$ Even within the Westernized area, the U.S. manifested its influence through huge investments in the economies of Japan and Europe, particularly Germany. Apart from an increasing monopolization of capital, the economy became ever more fictitious, being based primarily on speculations on assets and debts without the necessary back-up through production, which was outsourced to cheaper sites in developing areas in order to encourage American mass consumption.

Under the second Bush administration, the increasing fragility of the global finance system has caused a shift towards a more coercive, neo-conservative form of US hegemony. At the turn of the century, a rather influential think tank was established proposing geopolitical

\footnotetext{
${ }^{22}$ See William Blum, (2004). Killing Hope. Monroe, ME: Common Courage Press.

${ }^{23}$ Harvey, New Imperialism, op. cit., p. 66.

${ }^{24}$ Nakhleh, K. (2004). The Myth of Palestinian Development: Political Aid and Sustainable Deceit. Jerusalem: PASSIA, p. 13.
} 
strategies based on the notion of the 'American Century' - destined to take leadership in bringing freedom and democracy to the rest of the world. The Project for the New American Century (PNAC), sponsored and supported by hawkish politicians such as Wolfowitz, Cheney and Rumsfeld, advocated a unilateral US foreign policy and a significant increase in defense spending in order to "challenge regimes hostile to [their] interests and values", thus shifting the focus toward the territorial logic of power. ${ }^{25}$

At all times, this growing expansion of hegemonic influence and dominance throughout the world has been accompanied by differential socio-economic development between those regions constituting the source of power and those that have fallen under the authority of the dominant forces. The result is visible in today's 'civilized', globalized world, where industrialized societies are highly dependent on cheap material resources and exploitative labor practices in underdeveloped countries. Despite efforts to reduce hunger and poverty through 'free trade' agreements, open markets and neo-liberal strategies, the uneven distribution of wealth remains an issue on the regional as well as global level.

The fact that uneven development is ever present hints at the complexity of the issue at hand. Whereas a variety of approaches toward an understanding of uneven development has been attempted over the years, it seems in fact nearly impossible to ascribe one specific theory capable of explaining the phenomenon in its entirety. In his latest contribution to further develop the theory of uneven geographical development, Harvey has identified four "key conditionalities" of uneven development:

1) The material embedding of capital accumulation processes in the web of socio-ecological life.

2) Accumulation by dispossession.

3) Accumulation in space and time.

\footnotetext{
${ }^{25}$ See PNAC, Statement of Principles at http://www.newamericancentury.org/statementofprinciples.htm.
} 
4) Political, social and "class" struggles at a variety of geographical scales.

The following review of these components will show their interrelation with the elements of capitalist imperialism discussed above.

The capitalist mode of production entails the commodification of basically all aspects of life, including private property, labor power and skills, cultural traits and local customs of an area. To the extent that processes of capital accumulation are grounded in our everyday life, we are directly affected by the positive and negative outcomes thereof. While we may benefit from investment in new infrastructure and housing, we are disadvantaged by the relocation of production facilities resultant in the mass layoff of workers. The building of a new power plant might create employment opportunities, but destroys the natural environment to an immeasurable extent. All outcomes are part of the way capital accumulation processes are embedded into the social structure of our daily routine. Harvey emphasizes that the question of how such processes are manifested in and how they transform social relations is crucial for a theoretical framework.

With the formation of dominant class powers at the base of the capitalist system, a major process of uneven development is the accumulation/devaluation of capital through dispossession. The capitalist mode of production entails not only the strife for generating surplus values; it is primarily a matter of how to control and appropriate those surpluses and the means to produce them. This requires the dominant capitalist class to take advantage of weaker elements of society and dispossess them of the use values (land, labor, raw materials) necessary for capital accumulation. Dispossession takes place in various forms within, or in expansion of, a capitalist system. As has been seen in early mercantilist, colonial, imperial and later neo-colonial practices, coercive forces may be used to penetrate non-capitalist societies and geographical terrain to 
utilize the resources of that power, often played out under the disguise of development policy. ${ }^{26}$ A major part of the British imperial expansion to South and Southwest Asia was conducted on the premises that the forcefully occupied territories were highly underdeveloped and backwards, thus in need of British trusteeship and investment. In addition, dispossession may occur within a capitalist system itself, where factional class powers seek to acquire or destroy assets of rivals (finance capital seizes assets of farmers, stripping assets through mergers and acquisitions).

How do these processes of capital accumulation occur through space and time? Competition within and between capitalist markets entails not only the geographical division of labor; competitive advantage can also be achieved by capitalists occupying superior terrain and neglecting less valuable land. Once a territory's potential for generating surplus is recognized, investments are made and capital is fixed in form of physical infrastructure for production and consumption. The profitability within a given region, however, is generally restricted, thus forcing a continuous expansion of capitalist powers. As surpluses of capital and labor can no longer be absorbed in the existing infrastructure, capitalists are in need of a 'spatial fix' provided by new investment opportunities either locally or abroad. These opportunities are seized - or, if necessary, created - through the capital and territorial logics of power. At a local or regional scale, devalued assets are released at very low cost and can be seized by the over-accumulated capital for profitable use. ${ }^{27}$ If liberal economic practices of privatization prove to be an insufficient means to this end, dominant powers tend to utilize coercive forces as seen in colonial and imperial practices. Once the domestic market is exhausted, a spatial expansion of capitalist means is inevitable.

\footnotetext{
${ }^{26}$ Harvey, Uneven Development, op. cit., p. 92.

${ }^{27}$ Arrighi, op. cit.; Harvey, New Imperialism; Uneven Development, op. cit.
} 
It is little surprising that the encroachment of capitalism is met with resistance by those elements of a society that fall victim to the dispossession process. While the most obvious struggles occur over land, living space and natural resources such resistance is often interwoven with struggles over ethnic or religious identity, as seen in the long-standing conflict between Israel and Palestine. ${ }^{28}$ Harvey points out that, while the occurrence of social contest is rather apparent, the challenge lies in unraveling the complexity of the inner connections between such struggles and the overall process of capital accumulation.

In light of the expansive and oppressive nature of the capitalist mode of production, uneven development is understood as the 'essence of capitalism'. Indeed, it may be argued that the capitalist system functions primarily upon the existence and utilization of differential spatial development. In agreement with Smith and Harvey, Soja argued that the capitalist mode of production has been established and expanded through the "distinctive occupation and production of space ... the differentiation of centers and peripheries, and the penetration of the state into everyday life." 29 This phenomenon of uneven geographical development is intrinsically linked to capitalist imperialism. As Soja concludes: "the capitalist mode of production actively creates, intensifies, and seeks to maintain regional or, more broadly, spatial inequalities as a means for its own survival." ${ }^{30}$ Here, once again, the socio-spatial homology becomes apparent, whereby "core and periphery are the spatial expressions of the same underlying relations of production which define bourgeoisie and proletariat." 31 Just as the vertical, social axis is defined through the exploitative relationship between the dominant classes and labor, we find on the spatial axis, that the peripheral areas are not only dependent on but exploited by the core

\footnotetext{
${ }^{28}$ Harvey, Uneven Development, op. cit., p. 110.

${ }^{29}$ Soja, Socio-spatial dialectic,op. cit., p. 213.

${ }^{30}$ Ibid., p. 221.

${ }^{31}$ Ibid., p. 222.
} 
countries, whose growth and enrichment is based on the utilization of resources from the lesser developed world without returning the due costs in a socio-economically just manner. Similarly, the division and unevenness between industrial and agricultural areas is as much a social phenomenon as it is spatial. We must hence conclude that the spatial environment cannot be isolated from the social structure, but rather a given system is to be understood as socio-spatial, with internal and external forces affecting both the spatial and the social component.

\subsection{The Multiplicity of Space}

In order to analyze the complexity of the socio-spatial processes of uneven development, it is imperative to conceptualize space beyond the colorless container of the absolute; as the space of capitalism is socially produced to the extent that the organization, use and meaning of space are a product of social activities. ${ }^{32}$ We thus have to understand space as dialectically interrelated and intertwined with the social relations of production. Soja recognized that the structure of organized space is thus part of the general relations of capitalist production. ${ }^{33}$ As the dominant relations of production are reproduced in social space, space is occupied by advanced finance capitalism, centralizing control and eventually leading to an increasing unevenness in geographical development.

In an attempt to conceptually broaden our understanding of space, Harvey has argued that, rather than merely defining "what is space", we should consider "how different human practices create and make use of different conceptualizations of space." As early as 1973, he noted that

\footnotetext{
${ }^{32}$ Ibid.

${ }^{33}$ Ibid., p. 208.
} 
[i]f we regard space as absolute it becomes a 'thing in itself' with an existence independent of matter. It then possesses a structure which we can use to pigeon-hole or individuate phenomena. The view of relative space proposes that it be understood as a relationship between objects which exists only because objects exist and relate to each other. There is another sense in which space can be viewed as relative and I choose to call this relational space - space regarded [...] as being contained in objects in the sense that an object can be said to exist only insofar as it contains and represents within itself relationships to other objects. ${ }^{34}$

The realm of the absolute is - as the term suggests - the primary space of the discrete and tangible, of territorially bounded objects of varying size: from the body to a household to city or state. For that reason, the notion of absolute space is rather limited in analytical power. On the other hand, relative space takes into consideration the perspective of a given space, its features in relation to other realms. Locations are thus understood and evaluated relative to a central place, its distance in terms of time, cost or energy. The local hospital might be of great significance relative to the city and surrounding villages; its importance declines, however, for people living hundreds of miles away. Space is also relative in terms of time, particularly when we think about the friction of distance - as expressed both in Tobler's Law and location theory - and its impact on transportation. This takes an entirely new stand given the annihilation of space through time in the era of globalization and advanced capitalism. There are, however, limits to the positivist paradigm which looks at space from the absolute and relative perspective. The dialectical approach allows us then to go beyond these restrictions by taking into account the relational aspect of space, i.e. the notion that everything exists only as an internal relation with everything else. In other words, a subject or object is defined not only through its mere physical existence, but through its relationships with its spatial and temporal environment. It is the significance of these relations that gives meaning to things and their existence in space.

\footnotetext{
${ }^{34}$ Qtd. in Harvey, Uneven Development, op. cit.
} 
Harvey emphasizes that, rather than bringing the three concepts into a fixed hierarchical order, the key to successful analysis is the interconnectedness of all three. Yet, he acknowledges that a hierarchy exists to some extent, as absolute space is embraced by the relative, and both are contained in relational space. In other words, an event can happen in absolute space, while at the same time it has a relative and relational, spatio-temporal component to it. $^{35}$

In an attempt to visualize this interconnectedness and the impact thereof, Harvey has proposed a spatial matrix (see figure 2), which places these conceptual notions of absolute, relative and relational space on a vertical axis put up against the horizontal, comprised of a tripartite division of space proposed by Lefebvre: experienced, conceived and lived space. The first of Lefebvre's categories, i.e. experienced space, entails the tangible, material world as we experience it with our senses, whereas the second category, i.e. conceived space, refers to how space is represented in an abstract way, based on our understanding and reflection of the material world. These representations of space include maps, graphs, and literal accounts, but also artistic expressions such as poetry, pictures or architecture. The representation expressed through art often reflects spaces of the third category, i.e. lived space: our emotions, fears, imaginations and the extent to which these psychologies impact the way we experience and interact with our environment. $^{36}$

While this theoretical division of space according to Lefebvre assists us in the process of conceptualization and abstraction, the key is, once again, to understand the dialectical relation between the three categories. Our physical experience of the world is often influenced by our preconceptions, our knowledge and experience, as well as ideological and moral settings. Thus the spaces of representation, i.e. the lived space, are partially responsible for what happens in the

\footnotetext{
${ }^{35}$ Harvey, Uneven Development, op. cit., p. 126.

${ }^{36}$ Ibid., p. 131.
} 
material world and our conception thereof. At the same time, our fears and emotions influence the way we represent space and spatial relations. A migrant might thus have an entirely different experience of a given space, say, the capital of a developed country where he seeks asylum, than the native who spent all his life there. Places in the new environment may remind the immigrant of wartime experiences from home; and thus take on a meaning which the native does not share. If both were to draw a picture of the same city, we are likely to get two rather different results. ${ }^{37}$ Reversely, a tourist from the developed world traveling to 'exotic' places in the Caribbean is unlikely to experience the poverty and hardship which comprise the material world of the locals, but rather take home romantic memories from lonely beaches and sunsets. The same phenomenon is true when moving beyond the individual level. In the US, Hawaii is considered an almost integral part of America. Yet, its native inhabitants, if asked about their social and national affiliations, consider themselves as Hawaiian, not Americans. Many of them take, in fact, a rather hostile attitude towards the US, remembering the dispossession of their land and resources which is not to be found in American history books. ${ }^{38}$

Finally, when looking at the spatial matrix as a whole, it is the intersection points of the matrix which are of interest to our analysis. The crossing points maintained by the Israelis in the West Bank and Gaza manifest themselves both in absolute and experienced space, in a sense that they are part of the built environment. Yet, the frustration Palestinians feel having to wait for hours to pass one of those checkpoints is directly associated with lived as well as relative space. In other words, it occurs at the intersection of the two in the matrix. In that sense, the focus on the points of intersection also helps us to analyze and abstract particular social factors, or

\footnotetext{
${ }^{37}$ Dr. John Perivolaris. Lecture. 2008, July 3. University of Loughborough.

${ }^{38}$ Al Jazeera English, Inside USA - The Other Hawaii, 2008, September 26.
} 
Relations, as they occur within the multiple spaces and the scalar fixes associated with them.

This will be addressed in the remaining two sections of this chapter.

\section{Material Space \\ (experienced space)}

\begin{tabular}{l|l|}
\cline { 2 - 2 } Abs olute & $\begin{array}{l}\text { walls, bridges, doors, stainways, } \\
\text { floors, ceilings, streets, buildings, } \\
\text { cities, mountains, continents, bodies } \\
\text { of water, te rritorial markers, } \\
\text { physical boundaries and barriers, } \\
\text { gated communities... }\end{array}$ \\
\hline
\end{tabular}

\begin{tabular}{l|l|}
\cline { 2 - 2 } Relative & $\begin{array}{l}\text { circulation and flows of energy. } \\
\text { water, air, commodities, peoples, } \\
\text { Space }\end{array}$ \\
information, money, capital: \\
accelerations and diminutions in the \\
friction of distance...
\end{tabular}

\begin{tabular}{|c|c|}
\hline $\begin{array}{l}\text { Relational } \\
\text { Space } \\
\text { (Time) }\end{array}$ & $\begin{array}{l}\text { electromagnetic energy flows and } \\
\text { fields; social relations; rental and } \\
\text { economic potential surfaces; } \\
\text { pollution concentrations; energy } \\
\text { potentials; sounds, odors and } \\
\text { sensations wafted on the bre eze }\end{array}$ \\
\hline
\end{tabular}

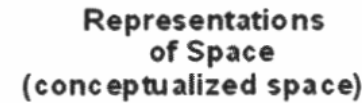

cadastral and admin istrative maps: Euclidean geometry; landscape de scription; metaphors of confinement, open space, location. placement and positionality; (command and control relatively easy) - Newton and Descartes

thematic and topological maps (e.g. London tube system); non-Euclidean ge ometries and topology:

perspectival drawings; metaphors of situated knowledges, of motion. mobility, displacement, acceleration. time-space compression and distanciation; (command and control difficult requiring so phisticated te chniques) - Einste in and Riemann

surre alism; existentialism; psychogeographies; cyberspace, metaphors of internalization of forces and powers; (command and control extremely difficult - cha os theory. dialectics, internal relations, quantum mathematics) - Leibniz, Whitehead, Deleuze, Benjamin
Spaces of

Representation

(lived space)

feelings of contentment around the hearth; sense of security or incarceration from en closure; sense of power from ownership, command and domination over space; fear of others "beyond the pale."

anxiety at not getting to class on time; thrill of moving into the unknown; frustration in a traffic jam; tensions or exhilarations of time-space compression, of speed, of motion.

isions, fantasies, de sires. frustrations, memories. dreams, phantasms, psychic states (e.g. agoraphobia

vertigo, clau strophobia)

Figure 2: General matrix of spatialities. (Source: Harvey, Uneven Development).

\subsection{The Concept of Scalar Fix}

While bearing in mind the interconnectedness of the four conditionalities of uneven development, the focus in this analysis will be placed on the process of accumulation through dispossession. How can we understand its internal relations with the help of geographical concepts? In this chapter I argue that the act of dispossession takes place through the means of 'scaling' spaces - and thus shaping and manipulating them - to the advantage of a dominant power. 
Geographers studying the concept of scale agree that its construction is based on social processes. Put differently, scale reflects the geographical structure of social interaction in space. ${ }^{39}$ Moreover, it is through the production - and fixing - of scale that space is structured and places are shaped. Smith defined the production of scale broadly as a "means of geographically organizing and expressing collective social action", therein providing a "platform and container for certain social activities. ${ }^{, 40}$ By extension, the scalar fix is conceptualized as a territorial organization of the corresponding socio-spatial processes, in other words, the bounding of political, economic and cultural activity. This involves first and foremost the steering of capital flows as well as the shaping of power relationships within and between states, including networking activities among cultural groups and ethnic, racial or religious identities. The most apparent way in which these processes present themselves is through the establishment of boundaries, formalized as nation-states or supranational regional organizations, or more informally through regions within a state. ${ }^{41}$

Research in geography has almost exclusively applied these concepts to the process of territorial organization as it occurs in the realm of absolute space, emphasizing therein a hierarchy of scales from local to regional, to national and global. The key role is hereby ascribed to the scalar fix of the nation-state and what Lefebvre termed the "state mode of production". According to Brenner, the state serves "both as a form of territorialization for capital and as an institutional mediator of uneven development in differential spatial scales." 42 Its determinate boundaries, well established institutions and set structures provide the ultimate scaffolding for

\footnotetext{
${ }^{39}$ Smith, N. (1993). Homeless/global: scaling places. In Bird, B. Curtis, T. Putnam, G. Robertson and L. Tickner (Eds.) Mapping the futures: local cultures, global change. (pp. 87-119). London: Routledge.

${ }^{40}$ Ibid., p. 61.

${ }^{41}$ Brenner, N. (2001). The limits to scale? Methodological reflections on scalar structuration. Progress in Human Geography, 25 (4), 591 - 614. Retrieved from Academic Search Complete Database. Also see Smith, Homeless/global and Brenner, Fixity and motion.

${ }^{42}$ Brenner, N. (1998). Between fixity and motion: accumulation, territorial organization and the historical geography of spatial scales. Environment and Planning D: Society and Space, 16, p. 462.
} 
the social relations of capitalism and thus enable the "mobility" and "transcience" of labor power, commodities and capital. ${ }^{43}$ It is the state's rigidity - or fixation - which provides a secured platform for capitalist growth, as it facilitates and controls the process of increasing centralization and concentration of capital, either in urban centers or by multinational companies. In doing so, it utilizes and manipulates multi-scalar structures within and beyond the state, funneling capital flows to urban, regional and global scales. The extent to which the state plays a role in the accumulation of capital, however, varies from case to case, with socialist democracies taking a more protectionist approach than liberal economies. ${ }^{44}$

While the state provides the legal framework, financial accumulation processes and decision-making with regards to production and reproduction take place at another scale: the metropolitan areas and urban centers. These control points within the world of capital flows are connected and interdependent on a global level, the magnitude of which has become, more than ever, evident in the current financial crisis. Thus, while a distinctive hierarchy of the various fixed scales is extant, they are nevertheless coalescent in their function of interplay of fixity and motion.

It is important to note that, despite their rigidity, scalar fixes must display a flexibility which corresponds to the changing needs of the capitalist system. The function and structure of the state are thus altered over time as necessary adjustments to socio-economic processes are made. During the neo-liberal era initiated in the US during the 1980s, the role of the state was brought to a minimum, whereas now it exercises much more influence in response to the most recent accumulation crisis and the concomitant bankruptcy of financial institutions.

\footnotetext{
${ }^{43}$ Ibid., p. 469.

${ }^{44}$ Harvey, New Imperialism, op. cit., p. 92.
} 
The role of the state is also under constant change in relation to other scales. Thus we have seen a change in the role of the European nation-state as a scalar fix in the era of the EU. Re-structurations of scale-configurations at state level occur in times of accumulation crises, as can be seen in the reaction to the contemporary financial crisis, where we in fact see the state taking once again a stronger place in the capital system.

To the extent that the use of the concept of scale pertaining to the territorial organization of space has a significant impact on the social environment, it is associated with the social spaces described in Harvey's matrix. Swyngedouw, for instance, argued that scales are the "embodiment and expression of power relationships" and thus provide an arena of control and domination where social relations of (dis-)empowerment operate. ${ }^{45}$ In that sense, Swyngedouw shows how scale also becomes part of resistance as opponent groups utilize the very existing scalar structures designed oppress to rise against the dominant power. Similarly, Smith emphasizes that one aspect of scale is the political potential (and its translation into resistance movements) inherent in the production of scale. ${ }^{46}$

Scale is hence also conceptualized as a "resolution or abstraction employed for understanding social relationships" and may thus refer to socially drawn boundaries of difference and sameness. By marking a clear distinction of the 'other', scale is closely intertwined with notions of identity, which may be expressed - and exploited - through features such as race, gender, ethnicity or religion. ${ }^{47}$

\footnotetext{
${ }^{45}$ See Swyngedouw, E. (1997). Neither Global nor Local: 'glocalization' and the politics of scale. In K. Cox (Ed.). Spaces of Globalization: reasserting the power of the local. (pp. 137-166). New York and London: Guildford Press. ${ }^{46}$ Smith, Homeless/global, op. cit.

${ }^{47}$ Smith, N. (1992). Geography, Difference, and the Politics of Scale. In J. Doherty, E. Graham, and M. Malek (Eds.) Postmodernism and the Social Sciences. (pp. 57-59). London: Mackmillan.
} 
In setting the focus on the underlying social processes as they occur in space, I seek to apply the scalar concept not only to the absolute spaces of the city, state and region, but rather think it useful - for the purpose of this analysis - to expand the concept to the multiplicity of spaces as proposed by Harvey. Just as the notion of space is much more complex than the 'container' of absolute space, so should the idea of scale be taken as a multi-faceted concept. Several researchers in the field have already hinted towards such an application. Howitt, for instance, emphasized that "if social relations are always spatial..., then social and environmental relations are also always scaled." ${ }^{48}$ Moreover, as Brenner has pointed out in his eleven hypotheses pertaining the further study of scalar fix, "an analysis of the spatiality of scale is required in order to excavate [the] full sociospatial content" of sociospatial practices. ${ }^{49}$ It is thus essential to conceive scale not merely as a measure of size or level, but rather as a relation in itself. $^{50}$ As an abstraction comprising the dialectical elements of 'extension', 'level of generality' and 'vantage point', scale encompasses facets of time, culture, ethnicity and environment in a spatial setting that incorporates the lived and conceived space.

\subsection{The Scalar Fixes of Multiple Spaces}

The following section will introduce several scalar fixes as they occur in the various spaces, particularly the relational, perceived and lived space as well as the junctions thereof. To understand the origin of the practice of scaling spaces, it is helpful to begin with a review of the concept of spatial fix. As capital absorption within an existing structure reaches its limit, the system with its built environment and financial assets is threatened by loss and devaluation. One solution - or fix - to this problem is the expansion of capital towards new spaces, e.g. through the

\footnotetext{
${ }^{48}$ Howitt, R. (2002). Scale and the other: Levinas and geography. Geoforum, 33, p. 306.

${ }^{49}$ Brenner, Limits to scale, op. cit., p. 606.

${ }^{50}$ Howitt, Levinas, op. cit.
} 
incorporation of non- or pre-capitalist societies into the system. These new spaces need development in form of physical and social infrastructure and thus have a large potential to absorb surplus capital. From a long-term perspective, however, these spatial fixes are both spatially and temporally limited. Once all spatial barriers to capitalist flows are eliminated and the capitalist outreach is exhausted, existing structures need to be re-modeled in order to soak up excess capital and to satisfy - at least temporally - the immense hunger for profits. ${ }^{51}$ As Harvey points out:

the aggregate effect is... that capitalism perpetually seeks to create a geographical landscape to facilitate its activities at one point in time only to have to destroy it and build a whole different landscape at a later point in time to accommodate its perpetual thirst for endless capital accumulation.

There is no doubt that this spatial fix through the investment of excess capital in the built environment has a significant impact on the social structure of the targeted system. Thus, a secure inflow of capital into the newly opened-up spaces requires an ideological justification that wins not only domestic support of the expansive measures, but also a welcoming embrace, or at least acceptance, from the society upon which the newly constructed roads, factories, school and, hospitals are bestowed. This is accomplished through the mobilization of "nationalism, jingoism, patriotism and, above all, racism" but also the 'development doctrine' that portrays the industrialized world (or, in former days, the colonial powers) as benefactor for the developing countries. In that sense, the spatial fix expands beyond the physical space as legitimizing ideologies are expressed - or fixed - in the realm of the conceived space, addressing the fears and emotions of the lived space.

${ }^{51}$ Arrighi, op. cit., p. 36; Harvey, New Imperialism, op. cit., p. 101. 
How is this manipulation of space accomplished? What is the necessary socio-political framework, and what institutions need to be in place in order to facilitate capital flows within and throughout space and to secure a spatial fix of capital at times of accumulation crises? The incorporation of new spaces as well as the destruction and reconstruction of existing spaces entail - in one way or another - almost always various acts of dispossession. The feasibility of this process requires the appropriate institutions as well as an adequate power structure to control both geographical space and social environment.

To explain how this is secured, I will apply the concept of scalar fix to the multiple spaces of Harvey's matrix. While the scope of this thesis limits the discussion to a select few forms of scalar fix, it is important to note that all intersections in the spatial matrix potentially have a scalar fix associated with them. Moreover, a socio-spatial phenomenon may be affected by more than one scalar fix, as it expands over several spatial realms. The scalar fixes are thus interrelated in their impact on social space.

The remainder of this section introduces four types of scalar fix in their function of consolidating power, which will be applied to the situation of the Palestinian people in the following four chapters. The first way of scalar configuration is the passing of legislation and treaties which legitimize acts of dispossession that in return facilitate the expansion of capital. In his study of dispossessing indigenous people in Australia, Howitt found that a major component of dispossession has been the "construction of specific scales of social control" which facilitated the disciplining of indigenous people through banishing targeted groups from certain structures and institutions, or simply dishonoring existing treaties designed to grant certain rights. On a broader note, the issue of 'unequal treaties' has been a major, power-consolidating tool in the colonial - and arguably the post-colonial - era. The colonial powers of Europe designed trading 
agreements and treaties much to the disadvantage of the populations of the colonies. This type of scale politics also works in a negative way: by creating an "imaginary of absence", extant spatialities and scalar frames of the indigenous' social relations are either denied or erased, thus depriving the indigenous people of their mere existence. ${ }^{52}$ As will be shown in chapter 4 , a similar act of dispossession has happened to the Palestinian people, whose rights to land, resources and development have been denied since the beginning of Jewish domination in Palestine.

While these treaties are a form of consolidating power visible in open space, they are often facilitated through the establishment of networks in the background, and the cooperation of a group of people in pursuit of equal interests or a common objective. While networking is generally understood to be a spatial concept on its own, I argue that networks may function as a scalar fix in itself. The dominant elite that emanates from networking relations may use their power to the disadvantage of weaker elements of society. An analysis of Israel's coming to power, at the expense of an entire indigenous people, can only by fruitful if various networks and their flows of information, knowledge and finance across state boundaries are given their due consideration. This includes a wide range of networks from the cooperation of early Zionists with members of the powerful banking house of Rothschild a century ago, to the networking between the pro-Israeli think tanks and the US administration.

On a more abstract level, dispossession is aided through the scaling of gathering and disseminating of knowledge, for the things we learn and come to accept as truth are shaped and controlled in various ways. First, with respect to the information available to the general population, the media plays a crucial role in representing certain socio-spatial developments. While accusations of bias have long been made by critics of mainstream journalism, the majority

\footnotetext{
${ }^{52}$ Howitt, R. (2000, December). Nests, Webs and Constructs: contested concepts of scale in political geography.
} 
of people still assume the media to provide us with objective information. Thus, unaware of that portion of information which is either under-reported or outright ignored, we tend to accept the news reporting - as selective as it may be - as the general truth. The global mass media of film, television, and the internet affects and shapes our imagination of political, economical and social events. The media thus becomes a powerful tool to directly manipulate our conceived space, and indirectly our lived and the experienced space. Through their direct control over how we comprehend and envision the world we live in, the media may shape people's imagination and stoke fears of the unknown, of perceived threats.

Censorship in the media is particularly apparent in the reporting on the US' conduct in the current 'War on Terrorism'. Reports about torture used by US forces in Afghanistan and Iraq were hardly covered by the US corporate media. ${ }^{53}$ That is, if they were taken up at all by the Associated Press (AP), the self-acclaimed "backbone of the world's information system." On their own website, the AP prides itself to be the "essential global news network, providing distinctive news services of the highest quality, reliability and objectivity with reports that are accurate, balanced and informed." Yet, a clear bias in the AP can be seen in several instances, among them the movement to impeach then President George W. Bush initiated in 2005. While the AP did report on sporadic calls for impeachment on local and state level in a variety of states, it failed to assess the issue to be of national significance, ignoring polls in late 2005 which showed that a majority of Americans were in favor of impeaching Bush and making it look as if the national movement of impeachment did not exist. ${ }^{54}$ A strong bias, on part of AP as well as the corporate media, is also evident in the reporting on the Palestine-Israel conflict. It is no secret that a large portion of the media is owned and thus controlled by Jews, many of whom are

\footnotetext{
${ }^{53}$ Phillips, P. et al. A Study of Bias in the Associated Press. Project Censored. ${ }^{54}$ Ibid.
} 
outspoken Zionists. Moreover, the printing press has been pressured by the Israeli lobby to report in favor of Israel and to avoid any major criticism.

The power and influence of the media on public opinion further helps construct scales of discourse and terminology that play a key role in processes of uneven development, and acts of dispossession in particular. Once certain concepts and ideas about a specific event, a population or social structure take on a fixed shape, they acquire the status of truth, whether justified or not. In accordance with the interest of a dominant power, certain parts of populations are labeled as enemies of the state who threaten state security and thus justify action against them as necessary acts to protect the population. In the aftermath of WWII, McCarthyism propagated a 'Red Scare' creating an artificial threat of communism which led to the persecution, interrogation and even imprisonment of numerous Americans. In contemporary times, the most prominent example is found in the notion of 'terrorism' and the 'war on terror'. These and other numerous misrepresentations remind us of Orwell's Nineteen Eighty-four 'lexicon of opposites'. ${ }^{55}$ The invaders and destroyers are supposedly bringing 'democracy and freedom', while those who dare resist the invasion and oppression are the 'terrorists'. While it portrays itself as the innocent victim, the US has in fact fomented terrorism through its imperialist foreign policy over the years. A similar statement can be made about the Israelis, who claim to be the victims of terrorist acts after having evicted hundreds of thousands of Palestinians from their lands and homes.

A significant influence on knowledge is also taken in the more exclusive circles of academics. The scalar power play is here exercised through the surveillance of academic writings and teachings, as well as the check on careers of those who are not in line with mainstream policies. A professor whose lectures and writings do not comply with ideas of the ruling class may be denied a promotion. A course whose content is thought to go against what is desired to

\footnotetext{
${ }^{55}$ Pilger, J. (2007, July 26). How Truth Slips Down the Memory Hole. Antiwar.com.
} 
be spread as knowledge by dominant powers might be taken off the catalog due to pressure from certain power groups. The content of textbooks is often hotly debated, especially with regards to accounts of history. The discourse over what is considered "legitimate knowledge" is defined by “complex power relations and struggles among identifiable class, race, gender/sex, and religious groups." 56

Even more importantly, the writing of history has been (mis-)used throughout the centuries to scale people's perception of their environment in its spatio-temporal context. As has been noted, "histories of struggles are most often written by the victors." ${ }^{, 57}$ Little is mentioned in US history books of the brutal fate of the millions of African slaves who died during the transport from Africa to America. The same is true for the millions of Germans who had to face a brutal death under the advance of the Russians at the end of WWII. In both cases, the actual events are hardly acknowledged, let alone commemorated. As regards the story of Palestine, the Israeli historian Ilan Pappe introduced the idea of 'memoricide', the ultimate scalar fix dispossessing the Palestinians of their history, culture and identity while ascribing a history to the Jews which is primarily based on falsehood, but favors the Zionist cause. ${ }^{58}$

All these tools or means of dispossession within the field of public discourse evolve around one issue: the production and utilization of 'identity'. As research in social studies has shown, the manufacturing of an identity can be an extremely powerful tool, as it differentiates between two social structures or groups in a sense that renders one superior to the other, which in

\footnotetext{
${ }^{56}$ Apple, qtd. in Moughrabi, F. (2001). The Politics of Palestinian Textbooks. Journal of Palestine Studies, 31 (1), 5 $-19$.

${ }^{57}$ Stork, J. and S. Rose. (1974). Zionism and American Jewry. Journal of Palestine Studies, 3 (3), 39 - 57. See also Khalidi, R. (1997). Palestinian Identity: The Construction of Modern National Consciousness. Columbia University Press: New York.

${ }^{58}$ Nakhleh, K. (2008, March 21). Al Nakba of 1948. Counterpunch.
} 
our case translates to the Zionist Jews' conceived superiority over the Palestinians. As Edward Said concluded:

... the triumph of identity by one culture or state almost always is implicated directly or indirectly in the denial, or the suppression of equal identity for other groups, states, or cultures. ${ }^{59}$

Scalar fixes established within their historical-geographical contexts present a powerful tool determining and restraining a future development of scales. Hence, while the focus lies on the scalar frame of accumulation by dispossession, consideration will also be given to social struggle, which is often the result of acts of dispossession. There is, in fact a mutual dependence between these two components of uneven development, for oppressive regimes generally adjust their control mechanisms to the forms of resistance movements, which evolve as a response to oppression in the first place. Resistance against extant socio-spatial arrangements is thus confined within existing structures, i.e. scalar fixes. While this is certainly true for the scalar hierarchy of the 'absolute', the idea carries even greater significance if we think along lines of spatial representations and representations of space. Once a certain identity is constructed, the major challenge of social struggle lies in breaking down that identity. I shall thus argue that the Zionist identity has served as a scalar fix in the realm of the relational and representative which has been essential to the unfolding of the Israel-Palestine issue.

\footnotetext{
${ }^{59}$ Said, E. (1994). The Politics of Dispossession: The Struggle for Palestinian Self-Determination, 1969-1994. New York: Vintage Books, p. 356.
} 


\section{CHAPTER 4:}

\section{CONSOLIDATION OF POWER THROUGH LEGISLATION AND POLICIES}

\section{Introduction}

This chapter examines how laws and policies have been used as a scalar fix to manage the Palestinian population according to the interests of the dominating power, i.e. the Zionist movement/Israel. The events and social factors chosen for this narrative show not only how particular acts of legislation facilitated seizing power, but also how to maintain it while suppressing social struggle from those being dispossessed. We will see how both official laws and treaties as well as informal, but no less influential plans and policies legitimized and institutionalized Zionist colonial rule at the expense of the formation of a Palestinian sovereign state. Going beyond the level of establishing Zionist domination in the geographical area of Palestine, this chapter also highlights imperial aspirations of foreign, hegemonic powers, first the Ottoman and then the British Empire.

The chapter is arranged in six sections, which follow, as far as possible, a chronological order of the Palestine-Israeli conflict. Each section addresses a separate, yet interrelated, social factor that builds a dialectical relationship with the overall scalar fix Relation. The first section looks at the beginning of foreign intervention in Palestine, triggering the first significant changes to its social structure. This is followed by an analysis of the events and policies leading to the ultimate scalar fix in the sphere of absolute space: the establishment of the State of Israel. The second section of this chapter thus examines the Balfour Declaration, followed by an analysis of the events of 1948/49 in the third section. The remaining three sections address various forms of legislation in the post-state era and their impact on the dispossession of the Palestinians: the 
policies of Judaization, the Israeli rule over the Occupied Territories, and, finally, the peace process manifested in the 1993 Oslo Accord and its follow-up agreements. Once considered individually, these sections may be taken to a higher level of generality where they, considered as a whole, illustrate clearly the process of 'stealing the commons from under the goose'. Finally, it should be noted that, as this chapter focuses on the scalar fix of legislation, some of the events addressed here will appear again later on in the thesis under consideration from a different angle.

\subsection{The Beginning of Foreign Intervention}

Until restructuring efforts by the perishing Ottoman Empire in the late 1800s, the area today known as Palestine was characterized by a distinct socio-economic structure rather different from Western, capitalist principles. Despite the presence of some 50,000 Ottoman soldiers in the area, the indigenous people lived a rather autonomous life, primarily based on subsistence agriculture and a system of social governance defined by kinship and family relations. The system of land tenure was not based on private ownership, but title to land use was ingrained in the masha'a system of collectivity which centered around village clans or families. ${ }^{60}$

In an attempt to increase revenue from its sub-provinces - those of Palestine being Nablus, Acre and Jerusalem - the Ottoman Empire introduced the 1858 Land Code (Land Reform). This new legislation provided for the issuance of title deeds and thus stimulated private ownership of the land. The reform had several severe effects on the traditional land tenure system and was, overall, to the disadvantage of the peasants, for it constituted a breaking up of the traditional masha' $a$ structure and its replacement by an individual land-holding system. ${ }^{61}$ Thus many peasants, failing to formally claim the title for the land they had cultivated for

\footnotetext{
${ }^{60}$ Pappe, Ilan. (2006). A History of Modern Palestine. Cambridge: Cambridge University Press, p. $14 \mathrm{ff}$.

${ }^{61}$ Zu'bi, N. (1984). The Development of Capitalism in Palestine: The Expropriation of the Palestinian Direct Producers. Journal of Palestine Studies, 13 (4), p. 93.
} 
generations, lost their rights to property to those who had the means to land acquisition: tax collectors, moneylenders and urban nobles. ${ }^{62}$ The increasing dependency on the new landowners, many of whom resided in remote places like Beirut and Damascus, also signified the deprivation of the people's socio-economic rights and the end to their self-sufficiency. This change in relations opened up first opportunities to establish the practice of hired labor, forcing peasants who could not afford it to give up farming the land and work under the big landowners who had little interest in subsistence agriculture but set out to commercialize the land, changing the system to cultivating profitable cash crops which could be exported as raw materials to Europe. This transition of peasant life is of critical importance for the course of events that were to unfold throughout the following century and half. Not only did it affect a fundamental change of the political and economic structure of society, the peasant transition would also provide the base for recruits to the Palestinian resistance movement.

Simultaneously to the Ottoman reforms in the mid $-19^{\text {th }}$ century, the traditional structures were grossly disrupted by an increasing penetration from European powers. As a result of the scramble for control over the much coveted 'Holy Land' and its indigenous population, within which France and Russia had succeeded to patronize the resident Catholic and Orthodox Christians, Britain decided to cooperate with Prussia to create their own religious 'protégé' community consisting of the Jewish and Protestant population in the area. As their small number provided a rather limited opportunity to establish substantial influence in the region, immigration to the 'Holy Land' was greatly advocated in Europe. The resultant influx of missionaries along with merchants and capitalists from Europe further infiltrated the socio-economic structure with European values and the capitalist mode of production. As part of that, a local banking system

\footnotetext{
${ }^{62}$ Ruedy, J. (1971). Dynamics of Land Alienation. In I. Abu-Loghod (Ed.) The Transformation of Palestine: Essays on the Origin and Development of the Arab-Israeli Conflict. Evanston: Northwestern University Press, p. 124.
} 
was modeled after European institutions under the leadership of Jewish and Orthodox Greek financiers, ignoring the indigenous peasant population which was deemed little suitable for this task.

In summary, this section shows the manifestation of foreign influence in legislation and policies as a function of scalar fix, laying the groundwork for the destruction of an indigenous population and social structure which was to give way to a capitalist, Western system implemented and exercised by a Westernized immigrant population: the European Jews.

\subsection{The Balfour Declaration and the British Mandate}

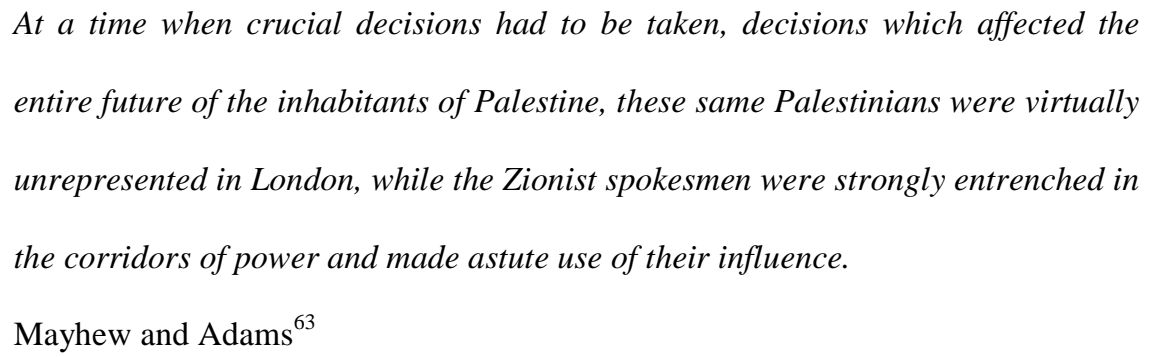

Perhaps the most significant document for advancing the Zionist cause is the Balfour Declaration from 1917, which has been understood as an official commitment from the British government to the Zionist plan of establishing a Jewish homeland (read: state) in Palestine. The statement issued in November 1917 confirmed that:

His Majesty's Government view with favour the establishment in Palestine of a national home for the Jewish people and will use their best endeavours to facilitate the achievement of this object, it being clearly understood that nothing shall be done which may prejudice the civil and religious rights of existing non-Jewish communities in Palestine or the rights and political status enjoyed by Jews in any other country.

\footnotetext{
${ }^{63}$ Mayhew, C. and M. Adams. (1975). Publish it not...The Middle East Cover-Up. London: Longman, p. 27.
} 
The issuance of a declaration in favor of the Zionists was not a spontaneous act but rather the result of a series of debate and negotiation stretched over a period of several months. The original 'formula' for the Zionist enterprise was submitted by the Jewish banker Lord Rothschild and proposed that

1. His Majesty's Government accepts the principle that Palestine should be reconstituted as the National Home for the Jewish people.

2. His Majesty's Government will use its best endeavours to secure the achievement of this object and will discuss the necessary methods and means with the Zionist Organization. ${ }^{64}$

It is not difficult to see that, in comparison, the initial proposal was much more straightforward than the final document, showing little attempt to conceal the Zionist motives. The reason for the not insignificant alterations lies in the differing positions of the three parties involved in shaping the declaration - the British War Cabinet, the Zionist Organization and the representatives from the non-Zionist Jewry of England - all of whom were intent on, naturally, pursuing their own agenda.

It is important to note that the support for the Zionists by both the British government as well as the War Cabinet had not existed as a longstanding policy, but was formulated as an official position only months before the Declaration due to several factors. One major aspect was the immense lobbying efforts by the Zionists, which will be addressed in the following chapter. For the time being, it suffices to consider the temporal and geopolitical context of this change in the official position at the time. While then foreign secretary, and eponym of the declaration, Sir Arthur James Balfour, had indeed been supportive of the idea of creating a Jewish state in Palestine, he initially preferred that a protectorate be under American responsibility. This attitude was to change, however, with Britain's increasingly precarious situation in the war. As Germany

\footnotetext{
${ }^{64}$ Ingrams, D. (1972). Palestine Papers 1917-1922: Seeds of Conflict. London: John Murray, p. 9.
} 
was advancing further into Russia, seeking to consolidate its power there, the British War Cabinet was in dire need for a political countermeasure. Realizing the imminent danger of an alliance of the Kaiser with the Zionist movement in Germany - which would have severely threatened both the British position in the war as well as its imperial interests overseas - the British War Cabinet decided to declare its sympathy with the Zionists and support their ambitions to create a national home in Palestine. The benefit for the British Empire was expected to be twofold: (1) to win the war and (2) to maximize Britain's position in its aftermath.

The temporal component was also decisive for the Zionists to gain the support from the Jewish elite born in England, many of whom - out of fear for their status as British citizens - had taken a rather anti-Zionist position. The events of WWI and the brutal persecution of Jews in Eastern Europe provided a unique window of opportunity for the Zionists to 'sell' their idea to their co-religionists. Whereas the increasing number of Jewry favorable towards the plan of creating a British protectorate in Palestine facilitated collaboration with the British war government, it remained the role of the British Jewry to intervene in the negotiations to protect the rights of Jews in Europe, a circumstance which was to benefit the indigenous population of Palestine. This is reflected in the second part of the official declaration, which provides a 'humanitarian clause' designed to protect the "civil and religious rights" not only for the Jews worldwide, but also of the indigenous population of Palestine. It should be noted here that the latter, the very people whose land was under discussion, were not consulted at all.

The exclusion of the native Palestinians was supported by Lord Balfour who did not deem it necessary to consider the "wishes of the present inhabitants", for Zionism "be it right or wrong" was more important than the "desires and prejudices of the 700,000 Arabs who now 
inhabit that ancient land," ${ }^{, 65}$ Consequently, while the declaration promised the Palestinians civil and religious rights, there was no mentioning of political rights, such as the right to selfdetermination and sovereignty.

The formation of the declaration thus reflects the power constellation at the time, which was to define the further development of the conflict. Even the reflection of British interests in the Declaration fades in comparison to those of the Zionists, who inarguably succeeded to express their objectives concealed under vague language - a style which was to become characteristic of Zionist and later Israeli policy making. As David Hirst comments:

The document bears Balfour's name, but in reality it was the Zionists themselves who, in very large measure, both inspired the Declaration and framed its text. It must be reckoned the finest flower of Zionist diplomacy at its most sophisticatedly ambivalent. ...suffice it to say here... that the Zionists who framed the declaration saw in it the charter of a future Jewish state... ${ }^{66}$

History has indeed shown that little attention was paid to the 'humanitarian clause' of the Declaration protecting the right of the Palestinian Arabs, an empty phrase merely added to appease the British Jewry and gain their support for the Zionist enterprise. On the contrary, the Balfour Declaration was to become the ultimate document - the scalar fix - to justify the establishment of a Jewish State in Palestine. Thus, the notion of inequality between Jews and Palestinians was a crucial factor of consolidating power, set to dispossess an entire people, from the very beginning, for it was "built into British, and subsequently Israeli and United States, policy from the start." 67

In order to obtain international recognition for this unilateral statement by the British government, the Balfour Declaration was incorporated into another act of legislation, providing

\footnotetext{
${ }^{65}$ Qtd. in Jadallah-Taschler, D. (2009, January 23/25). The Struggle of an Un-People. CounterPunch.

${ }^{66}$ Qtd. in Neumann, M. (2005). The Case Against Israel. Petrolia and Oakland, CA: CounterPunch and AK Press, p. 25.

${ }^{67}$ Said, E. (2000). The End of the Peace Process: Oslo and After. London: Granta Books, p. 314.
} 
another scalar fix: the Mandate for Palestine, assigned to Britain in 1922 by the League of Nations. While the Mandate contained various provisions to safeguard the rights of the Palestinians, its greatest significance was constituted in article 4, which recognized the Zionist Organization/Jewish Agency as the public body charged with facilitating the Jewish immigration process under the control of the Palestine Administration.

The creation of the mandate, based on the Balfour Declaration, marked a new era for Palestine as it gave a significant uplift to the Zionist enterprise and the creation of Jewish settlements in the region. The Israeli geographer and historian Gideon Biger describes the significance of this development as follows:

We have Great Britain to thank for creating a geo-political framework where only hazy notions had gone before. For the first time in hundreds of years, people understood that the territory of the south of the Levant [...] was in fact a distinct geo-political entity that was not part of the larger countries lying beside it. This was important because it finally allowed the region to develop on the strength of its own resources... The inhabitants could now focus their energies on development within a defined circumference, and lay the basis for $[\ldots]$ a 'national image' and 'spatial iconography', namely symbols, values, and acts that define the physical and human geography of a specific territory. ${ }^{68}$

For the Zionists, this meant that their enterprise was now taking shape, being given an official geographical conceptualization and spatial representation of their idea of Eretz Israel. For the Palestinians, on the other hand, the Mandate rule was a catalyst to develop a stronger resistance to what they well knew was a threat to take over the territory in which they had lived for hundreds of years. Thus Arab violence against both British rule and Zionist invaders increased considerably during the 1920s and 1930s.

\footnotetext{
${ }^{68}$ Biger, G. (1994). An Empire in the Holy Land: Historical Geography of the British Administration in Palestine 1917-1929. New York and Jerusalem: St. Martin's Press and Magnes Press, The Hebrew University, p. 67.
} 
The Balfour Declaration as a function of scalar fix served as a conceptualization of space in that it provided a geopolitical framework with territorial boundaries. Yet, its impact clearly went beyond the sphere of conceptualized space, for it was not the actual wording of the Declaration, but the intention of its makers and interpretation by those in power which lent it its significance. It was this sense of power from ownership, the command and domination over space which we find at the intersection of absolute and lived space in Harvey's matrix of spatialities, which gave the Balfour Declaration - and through it the Mandate over Palestine - its leverage as the powerful tool of dispossession it was to become.

\subsection{The Plan for Ethnic Cleansing and the Establishment of the State of Israel}

Britain's increasing failure to handle Arab resistance, as well as its weakened position at the end of World War II, led to the decision to abandon the Mandate in 1948. Leaving Palestine without any arrangements for a follow-up administration presented a structural vacuum which the Palestinian leadership - plagued by disunity and lack of organization - was not positioned to fill. ${ }^{69}$ The Zionist leaders, on the other hand, seized the opportunity and began preparations to take over official leadership as early as May 1946.

Following an examination of the situation in Europe as well as in Palestine by several international committees in the aftermath of WWII, UNSCOP (United Nations Special Committee on Palestine) proposed a Partition Plan which paid little attention to the reality on the ground but rather constituted "a radical territorial redistribution in favor of the Zionists.",70 The plan allocated $55 \%$ of the land to a Jewish state, ignoring the fact that the Jewish inhabitants comprised less than one third of the overall population, holding less than $7 \%$ of the land (see

\footnotetext{
${ }^{69}$ Pappe, History of Palestine, op. cit., pp. 122-35.

${ }^{70}$ Khalidi, W. (1988) Plan Dalet: Master Plan for the Conquest of Palestine. Journal of Palestine Studies, 18 (1), p. 14.
} 
figure 3). ${ }^{71}$ Even more problematic was the fact that nearly half of the people within the proposed Jewish state were Arabs. A mere glance at these figures leads to suspicion about the practicality of this solution to the Palestinian question. Would the Palestinians, who had repeatedly voiced their objection to a partition of their land, but had failed to propose an alternative solution, accept this plan? Would the large Arab minority within the Jewish state be treated fairly? While there was reluctance among the UN member states to accept the partition plan, continuous Zionist lobbying efforts, particularly in the US resulted in an approval of the plan, with thirty-three states voting yes, thirteen no, and ten abstaining from their vote. ${ }^{72}$

The Zionists took this as encouragement for the next step of their Judaization project, i.e. the eviction of as many Palestinians from the potential Jewish state as possible. The expulsion of a large proportion of the indigenous population by force had been meticulously planned, making use of vast amounts of intelligence about the Palestinian villages which had been gathered in minute detail by the Zionists. Several documents outlining these plans were issued, the most detailed being Plan Dalet, ${ }^{73}$ which gave exact information about the demographic and geographic composition of the villages and clear instructions for them to be attacked and in most cases destroyed (see Appendix A). This shows that the brutal measures were not randomly committed and should not be attributed to intangible factors such as "the circumstances", but were part of a distinct overall plan to change the demography in the area in favor of a Jewish majority. ${ }^{74}$ The systematic approach to ethnic cleansing started in March 1948 - two months prior to the end of the British Mandate and before the outbreak of the war with the Arabs.

\footnotetext{
${ }^{71}$ Ibid., p. 12. Lesh, Ann. (1989). Palestine: Land and People. In N. Aruri (Ed.) Occupation: Israel over Palestine. Belmont, MA: AAUG Press. p. 34.

${ }^{72}$ Morris, B. (2001). Righteous Victims: A History of the Zionist-Arab Conflict, 1881-2001. New York: Vintage Books, p. 186.

${ }^{73}$ Khalidi, Plan Dalet, op. cit., p. 4.

${ }^{74}$ Pappe, I. (2006). The 1948 Ethnic Cleansing of Palestine. Journal of Palestine Studies, 36 (1), 6 - 20.
} 


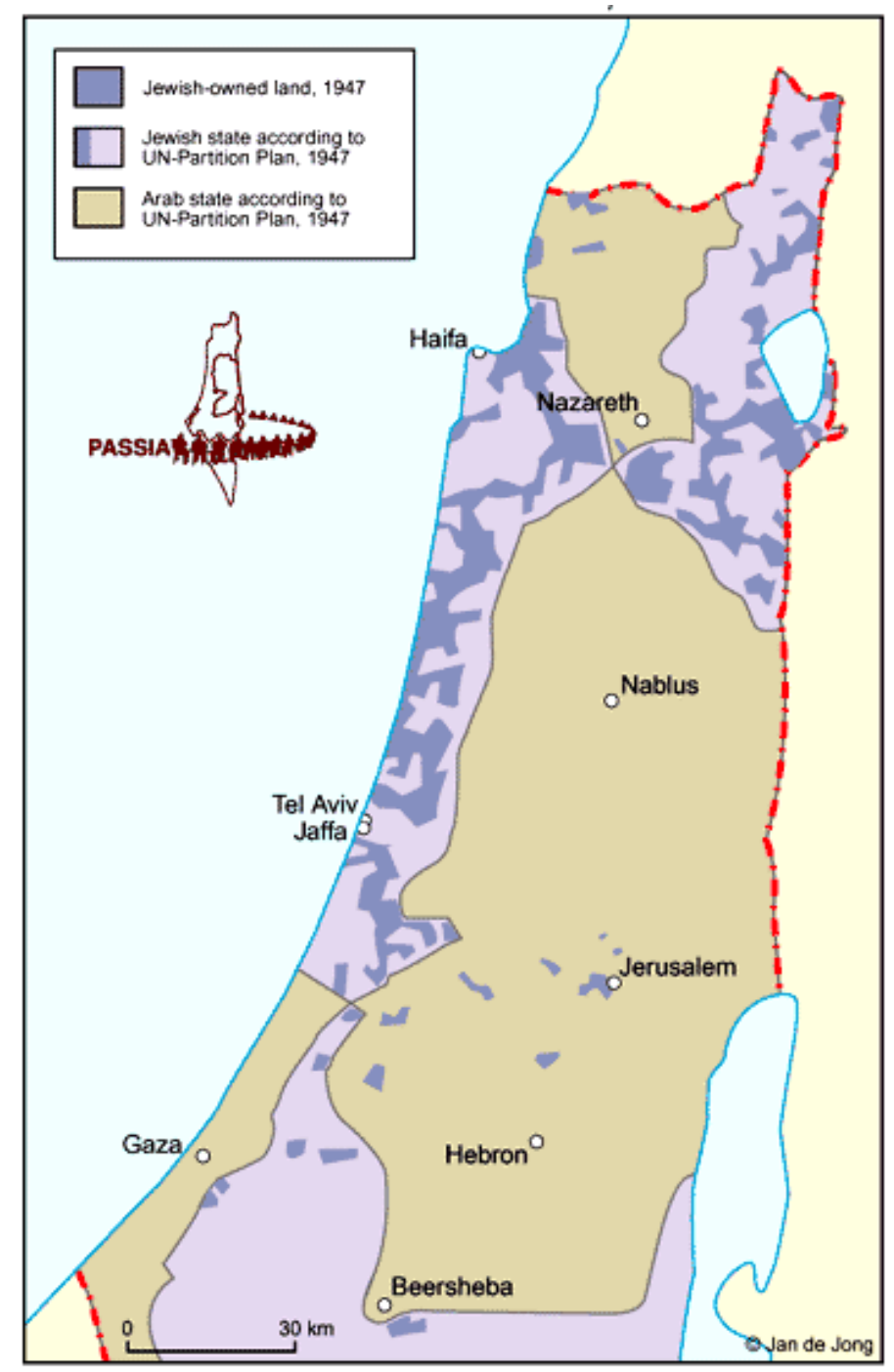

Figure 3: Landownership in Palestine and the UN Partition Plan, 1947. (Source: PASSIA)

It is important to recognize the significance of Plan Dalet as scalar fix, which established a Jewish majority in Palestine by driving out the indigenous population. Without the measures prescribed in the plan the declaration of an Israeli state would not have been possible. Overall, the Nakbah (Arabic for catastrophe) resulted in the eviction of more than three-quarters of a 
million Palestinians from their homes. ${ }^{75}$ Those who had been living in the territory designated by the UN as the Jewish state were affected the most: out of 850,000 inhabitants only 160,000 remained. After bulldozing hundreds of villages in rural Palestine and altering the landscape "beyond recognition," the next step was to change the Arab names of the villages into Hebrew to emphasize the Jewish character of the new settlements that were to be built and, as David BenGurion explained, "to prevent future claim to the villages.",76

The troops sent by neighboring Arab countries in order to save the Palestinians from the Israeli onslaught came too little too late. Although almost equal in numbers, they were no match to the well-trained, well-disciplined and highly motivated Zionist brigades, many of whom had gained experience in the British army during WWII. The Arabs did succeed, however, in preventing the Zionists from taking over all of Palestine, for Yigal Allon admitted later on: "If it wasn't for the Arab invasion there would have been no stop to the expansion of the forces of Haganah..."77 The armistice line drawn in 1949, which was internationally recognized as Israel's official border, enlarged the Jewish state significantly, leaving a mere $23 \%$ of the proposed Palestinian state for the Arabs (see figure 4).

The recognition of the state of Israel through the UN may be considered as the ultimate scalar fix in terms of bounding the territory of absolute space. Yet, more importantly, it consolidated Jewish power in granting Israel full sovereignty as a state with all the rights and obligations defined by international law and consensus. The pre-1948 structures and organizations were now transformed into elements of the state. The Haganah, which had been mainly responsible for resistance against British rule and the ethnic cleansing of the Palestinians,

\footnotetext{
${ }^{75}$ The Israeli historian, Ilan Pappe, speaks of almost one million refugees. See Pappe, I. (2007). The Ethnic Cleansing of Palestine. Oxford: Oneworld Publications Ltd

${ }^{76}$ Qtd. in Pappe, History of Palestine, op. cit., p. 138.

${ }^{77}$ Qtd. in Khalidi. Plan Dalet, op. cit., p. 19.
} 
was converted from an "illegal underground organization""78 into the Israeli Defense Forces. On top of that, even terrorist groups like Irgun and Stern were successively incorporated into the state army - although not until they had done their service as terrorist organizations, including the assassination of UN mediator Count Bernadotte. ${ }^{79}$

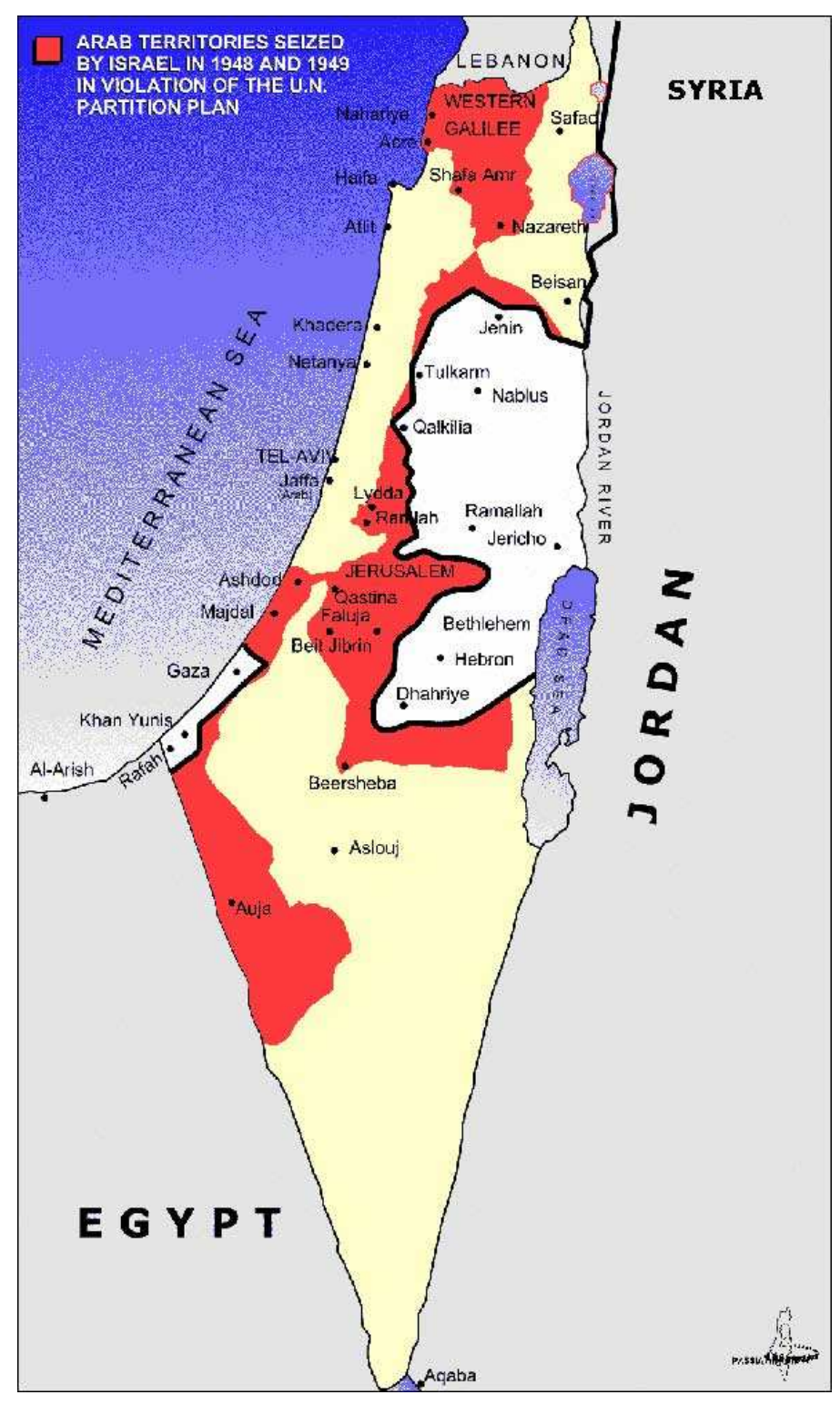

Figure 4: Arab territories seized by Israel in 1948/49. (Source: PASSIA)

\footnotetext{
${ }^{78}$ Some scholars describe Haganah as terrorist organization as well. See Wright, C. (1989). Facts and Fables: The Arab-Israeli Conflict. London: Kegan Paul International, pp. 45 - 56.

${ }^{79}$ Morris, Righteous Victims, op. cit., p. 237.
} 
The new state was inherently discriminatory towards its Arab population, for according to its courts, Israel constitutes "the sovereign State of the Jewish people." This does not only refer to "the people residing in Israel, but also [to] the Jews in the Diaspora." Hence, an Israeli nation that equates to the world Jewry excludes, by definition, any non-Jewish population from citizenship. ${ }^{80}$ Although the Palestinians who had succeeded to remain on their lands were granted citizenship - turning them into 'Israeli Arabs' - they have been treated as 'second-class' citizens ever since, a point which will be addressed later on.

Most importantly, the new state institutions provided the Zionist organization with the necessary authority to legitimize their project of colonizing Palestine. Whereas land had been acquired in the free market during the pre-state period, it could now be appropriated in a more 'efficient' manner, with the state apparatus able to pass necessary legislation to justify and facilitate confiscation of the land. Thus the power of the Zionist Jews, defined by their distinct political, economic and social dominance, was further consolidated and legitimized, providing the legal framework for continuing land redemption and consolidation of Jewish hegemony.

In addition to the large-scale dispossession of the Palestinians, the Jews took over everything left behind by the British, including military bases and bank accounts. The British, after having left the Palestinians at the mercy of the Zionists, were thus complicit in making the dispossession of the Palestinians complete: in the early 1950s the governmental accounts for the Mandate located in London were handed over to the Jews, depriving the Palestinians from any share of the wealth that had been accumulated during 30 years of British rule. ${ }^{81}$

The Palestinians, on the contrary to the Jews, have to this day not come to enjoy the privilege of statehood. This state of tremendous imbalance - Israel's sovereignty and Palestine's

\footnotetext{
${ }^{80}$ Chomsky, N. (1999). Fateful Triangle: The United States, Israel and the Palestinians. Cambridge, MA: South End Press, p. 45.

${ }^{81}$ Pappe, History of Palestine, op. cit., p. 134.
} 
non-sovereignty - has been of great significance for the relations of the two people as well as the wider area of the Middle East, as has been shown in the latest violent outbreak, the war on Gaza. While Israel claims the right to self-defense and the use of arms in order to protect the population of its state - rights which are recognized by fellow UN member states - the Palestinians in Gaza are internationally condemned for having to resort to illegal measures such as the smuggling of weapons - their only means to be able to engage in self-defense, a right they are deprived of in the absence of sovereignty.

Whereas the declaration of Israel's statehood - and Palestine's lack thereof - is a key point in the consolidation of Zionist power, it is also imperative to consider its representation in the aftermath, i.e. its impact on the conceptualized and lived space, which will be addressed in chapter 6. At this point, we can conclude that not only the declaration of the State of Israel functioned as a scalar fix. Perhaps even more importantly, it was the scalar fix of policy making in form of unofficial plans that facilitated the colonial, or capitalist-imperial, ambition of the Zionists.

\subsection{Judaization and the Consolidation of Territorial Boundaries}

Another aspect towards a full understanding of the extent of the Zionists' deliberately planned dispossession of the Palestinian people is the scalar fix of Judaization in conjunction with the consolidation of the territorial boundaries of Eretz Israel. From the outset of the Zionist colonization enterprise at the turn of the $20^{\text {th }}$ century, the territorial configuration of Jewish land holdings in Palestine, which was to lay the foundation for the state of Israel, was determined by the creation of another scalar fix: the seemingly irreversible 'facts on the ground'. As shown in figure 4 (p. 53), the Jewish settlements were strategically well positioned, and their location was 
strongly taken into consideration by the several committees appointed to investigate the situation in Palestine, eventually leading to the Partition Plan proposed by the UN in 1947. As Ghazi Falah points out, the settlement frontier determined the boundaries of the Partition Plan, a fact that was very well known to the Zionists who created Jewish settlements "in the Naqab [Negev] literally overnight" to ensure the area be included in the proposed Jewish state. ${ }^{82}$

The 'Green Line' represents another such 'fact'. After ignoring the initial borders proposed in the 1947 Partition Plan, the preliminary boundary between Israel and the remaining Palestinian lands was determined to be along the 1949 armistice line, an act which significantly increased the territory of the Jewish state. While originally drawn merely to depict the location of the armed forces at the time of the ceasefire, the Green Line has found wide acceptance - both by Israeli and Palestinian negotiators - as a default border between Israel and a potential Palestinian state, and as a premise for any peace negotiations. As a consequence of this institutionalization of the Green Line, demographic distribution of the Palestinian population was largely ignored, disrupting indigenous villages and townships. ${ }^{83}$

In order to ensure its 'Jewish character', land confiscations within Israel proper have continuously altered the territorial configuration of the state. The pre-state strategy was to establish core settlements in the most valuable and fertile areas of Palestine. The declaration of the state of Israel converted these Jewish enclaves within the majority Palestinian areas into officially recognized "national space of the new state." ${ }^{84}$ At the same time, it was the Arab land that was now turned into 'enclaves' within the Israeli state, rendering the remaining Palestinian villages more vulnerable to fragmentation and expropriation. Scholars have aptly described this

\footnotetext{
${ }^{82}$ Falah, G. (2003). Dynamics and Patterns of the Shrinking of Arab Lands in Palestine. Political Geography, 22 (2), p. 196.

${ }^{83}$ Newman, D. (2002). The Geopolitics of Peacemaking in Israel-Palestine. Political Geography, 21 (5), p. 637.

${ }^{84}$ Falah, Shrinking of Arab Lands, op. cit., p. 187.
} 
continuous process of deliberate dispossession as the "alienation" and "shrinking" of the Palestinian land aimed at the "Judaization" of Israel, ${ }^{85}$ a process through which the territory under Israeli control, a governmental or Zionist agency, has increased from some $77 \%$ after the $1948 / 49$ war to more than $90 \%$.

Several laws were put in place in order to facilitate the expropriation of Arab land, which is protected under the 1960 Basic Land Law, stating that the "ownership of lands, being the lands in Israel of the State, the Development Authority or the Keren Kayemet le-Israel [i.e. the Jewish National Fund], shall not be transferred either by sale or any other manner." ${ }^{86}$ As the State of Israel explains on its website, this law is based on "the special relationship between the People $\ldots$ and the Land of Israel and its redemption," $" 87$ providing a protective mechanism to ensure its exclusive use by Jewish people.

In addition, the Israel Land Administration has devised Master Plans for the development of Arab villages which deliberately exclude land privately owned and inhabited by Arabs. Demarcated as lying outside the jurisdiction area of the local municipality, and consequently excluded from officially recognized residential areas, the villages in these areas are barred from economic and social development and rendered more vulnerable to future dispossession. ${ }^{88}$ As a result, the Arab lands have become increasingly fragmented, aiding the Judaization policy of the Israeli government. In many cases the policy of non-development involves entire villages and townships that are primarily inhabited by Palestinians. To this day, there are hundreds of unrecognized Arab villages in Israel, manifestations of distinct Palestinian space, whose existence is categorically denied as they appear on no maps and are not included in

\footnotetext{
${ }^{85}$ Ibid., p. 181.

${ }^{86}$ Basic Laws of the State of Israel, qtd. in Falah, Shrinking of Arab Lands, op. cit., p. 188.

${ }^{87}$ State of Israel, Basic Laws: Israel Lands.

${ }^{88}$ Falah, Shrinking of Arab Lands, op. cit., p. $198 \mathrm{ff}$.
} 
any plans for socio-economic development. The fact of non-recognition enables the confiscation of this Arab land, as the expulsion of Palestinian inhabitants and their transfer into “concentration townships" goes literally unnoticed. ${ }^{89}$

With the beginning of the occupation of the West Bank and Gaza, similar policies were adopted to the areas outside Israel's sovereign territory. ${ }^{90}$ During the 1967 war and its aftermath the establishment of legal (i.e. by Israeli standards) and illegal settlements was justified as necessary to build a 'security zone' near the Green Line. Whereas in 1967 the Israeli government had brought $9.3 \%$ of the West Bank under its control, it had confiscated nearly half of the entire area by $2000 .^{91}$ Figure 5 visualizes the quantitative change in settlements in the West Bank, excluding East Jerusalem, since the beginning of the occupation. It clearly shows the significant increase in settlers in more recent years, jumping from 176,500 in 1999 to 275,156 in 2007 and defying all pledges and agreements to freeze settlement activities.

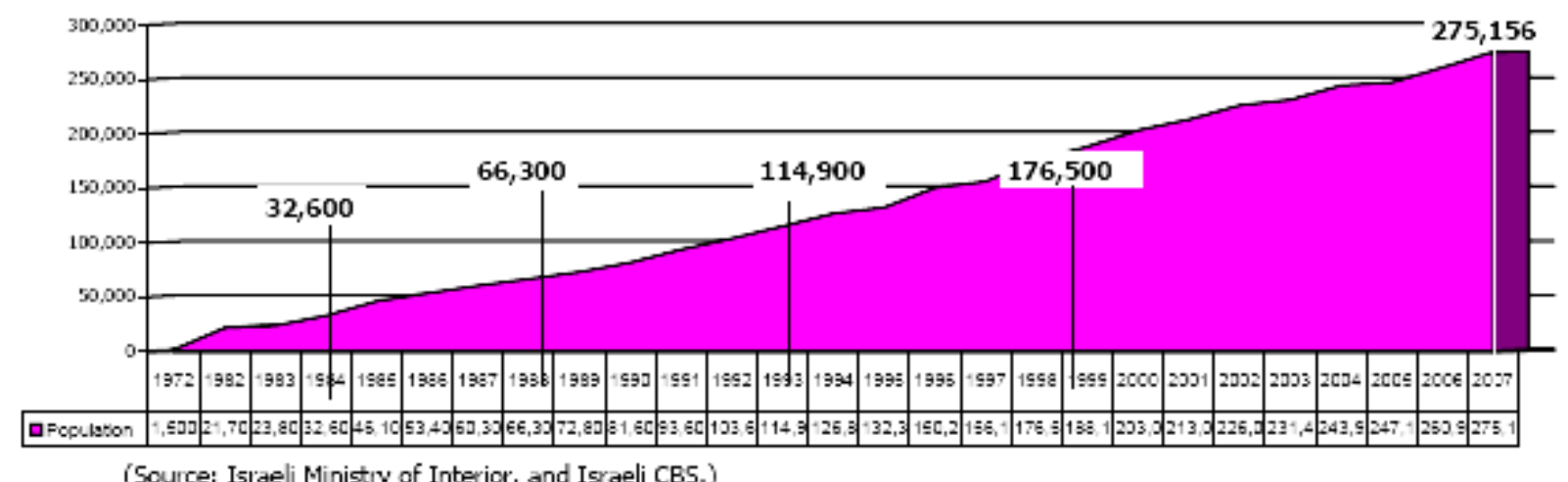

Figure 5: Growth of the settler population, excl. East Jerusalem. (Source: PASSIA)

\footnotetext{
${ }^{89}$ Schechla, J. (2001). The Invisible People Come to Light: Israel's 'Internally Displaced' and the 'Unrecognized Villages'. Journal of Palestine Studies, 31 (1), 20 - 31.

${ }^{90}$ Settlements were also built in the Sinai, which were dismantled after Israel's withdrawal, and Golan Heights, where they remain to this day.

${ }^{91}$ Reuveny, R. (2003). Fundamentalist Colonialism: The Geopolitics of Israel-Palestinian Conflict. Political Geography, 22 (4), p. 359.
} 
There are several dimensions to the way the Jewish settlements among Palestinians in the OT (Occupied Territories) have an impact on the conflict. Not only has the increasing number of Jewish settlers changed the social relationship with the Arabs, leading to increasing tension that translates into violence, it also consolidates Israeli control over the Palestinian territory and its people. The construction of the Jewish settlements - connected through bypass roads designated for Jewish use only - separate the Arab villages and townships from each other and disrupt Palestinian life. These settlements are - unlike the Palestinian areas - subject to Israeli law and receive preferential treatment in terms of political and civil rights. As will be shown in the next section, Israel's policy is to seize the land while managing the indigenous population in a way that denies them fundamental rights granted to the Jewish settlers.

Once these 'facts on the ground' have been created, they become a significant point on any negotiation agenda, ranking almost equally with critical issues such as Jerusalem and the right of return for Palestinian refugees. ${ }^{92}$ Thus, the longer those settlements exist, the more justified seems their existence, for an increasing number of settler descendants appear to make a reversal of the settlement process ever more unthinkable. Taking a step back to look at these 'facts' as a whole, we can consider the settlements as a dialectical Relation in itself and thus understand and appreciate the significance of the tremendous change that has occurred in Palestine, not by accident by through deliberate policies. To this day, the settlements in the OT have been a major obstacle to a solution of the conflict between Israel and Palestine. With resortlike housing complexes replacing degenerate villages and Zionist settlers displacing Palestinians into "concentration townships", the settlements are the manifestation of uneven development in the area. The settlement Relation thus shows clearly the Zionists' success of stealing 'the commons from under the goose."

\footnotetext{
${ }^{92}$ Newman, op. cit., p. 636.
} 


\subsection{The Military Administration in the Occupied Territories After 1967}

After its conquest of the West Bank and Gaza Strip within six days of June 1967, Israel established a new scalar fix to manage its newly obtained territories in form of a military administration, designed to utilize the territory for its own interests while neglecting the rights of the Palestinian people. While the previous legal system - Jordanian and Egyptian law for the West Bank and Gaza respectively - remained largely in place, ultimate authority was conferred upon the Israeli military commander, whose military orders (MO) - of which more than 2,500 were issued throughout the years of occupation - immediately became effective law. ${ }^{93}$ The military jurisdiction served several functions. Not only did the complex legal system sanction "the legality, legitimacy, and morality of the occupation," 94 the laws and institutions established by Israel were also designed to control literally all aspects of life in the OT and to shape the socio-spatial practices of the Palestinian people.

Apart from the military rule, a number of key institutions were utilized to control the population, first and foremost the General Secret Service (GSS), also known as Shin Bet. The enormous influence of the GSS went beyond the 'usual' information gathering, using surveillance methods similar to those of the Stasi apparatus of the German Democratic Republic. Most importantly, with no legal authority in charge of it, the GSS functioned above the law. This lack of accountability facilitated the agency's engagement in coercive activities such as illegal detentions and torture. ${ }^{95}$

Another control mechanism that interfered grossly with the socio-spatial practices of Palestinians has been what Israeli professor of politics, Neve Gordon, described as the permit

\footnotetext{
${ }^{93}$ Gordon, N. (2008). Israel's Occupation. Berkeley and Los Angeles, CA: University of California Press, p. 27. See also Shehadeh, R. (1989). The Changing Juridical Status of Palestinian Areas under Occupation. In N. Aruri (Ed.) Occupation: Israel over Palestine. Belmont, MA: AAUG Press, p. 118ff.

${ }^{94}$ Ibid., p. 28.

${ }^{95}$ Ibid., p. 31.
} 
regime. Palestinians in the OT had to obtain permits for nearly every kind of activity, from planting new trees for the citrus plantation, to carrying out any type of electricity work, to purchasing and operating a tractor. Permits were also issued, or more often not issued, to control and restrict the movement of people within as well as to and from the two regions, the West Bank and Gaza. Even the right for Palestinians to move freely within their cities and villages was often severely restricted through curfews and closures. A point in case is Hebron, where a 24hour curfew was imposed for four days during the Passover holidays in 1995 in order to allow Jewish residents and visitors to spend their holiday without the 'disturbance' by the locals. ${ }^{96}$

The act of issuing or withholding a permit was utilized as a tool to blackmail and manipulate individuals, as granting a permit was often conditioned on collaboration with the occupying power. Gordon points out that the permit regime transformed basic rights into privileges and thus shaped all types of social relations as well as the behavior of people. While this extensive surveillance and control mechanism was applied to the Arab population, the military rule did not apply to the increasing number of Israeli settlers in the OT. The highly unequal treatment of the two groups of people led to the growing dispartment between the Arabs and the Israelis, as well as increasing resentment by the former for the latter. ${ }^{97}$

Similar effects were produced through the perpetual inequity in formulating economic policies for the Palestinians and Jews, both in Israel proper and the Occupied Territories. Overall investment in the dilapidated economy of the OT was kept at a minimum as to avoid the development of a strong, sustainable economy and produce an increasing dependency on the patron, Israel. The net transfers the Israeli government received from the OT, which could have improved the development of Gaza and the West Bank significantly, were not reinvested in the

\footnotetext{
${ }^{96}$ Chomsky, op. cit., p. 546.

${ }^{97}$ Gordon, op. cit., pp. 33-40.
} 
area. As Sarah Graham-Brown observed in 1989, "it seems that the territories today largely finance the Israeli occupation, rather than vice versa." Indeed, the annual report of the administration for the fiscal year 1984/85 suggested that the occupation (excluding military expenses) "hardly costs the Israelis anything." 98

Instructive for our understanding of the occupation's crippling effects on the indigenous Palestinian economy is an extensive study on the economy of the Gaza Strip by AmericanJewish scholar Sara Roy, who has referred to Israel's policies as a "political economy of undevelopment." While Palestinian workers had to pay taxes at a much higher percentage than Israeli workers, they were not entitled to any benefits. In addition, whereas the Israeli agricultural sector was highly subsidized, there were hardly any financial incentives for Palestinian farmers and entrepreneurs in Gaza, thus making it impossible for them to compete with their Israeli counterparts. ${ }^{99}$

Another case in point illustrating the uneven development is the distribution of water rights. While military orders placed tight restrictions on water use as well as the digging of new wells for Palestinian farmers, the Jewish settlers enjoyed free usage of water and drilled between 35 and 40 new wells in Gaza within the first two decades of the military administration. To express this inequity in concrete figures: the Jewish settlers in Gaza used an average of 2,326 cubic meters of water per capita, whereas the water usage for Gazans amounted to merely 123 cubic meters per capita. ${ }^{100}$ Israel's economic policies were clearly designed to disable the Palestinian economy in order to contain the threat of competition and economically strengthen Israel.

\footnotetext{
${ }^{98}$ Graham-Brown, S. (1989). The Economic Consequences of the Occupation. In N. Aruri (Ed.) Occupation: Israel over Palestine. Belmont, MA: AAUG Press, p. 333/334.

${ }^{99}$ Roy, S. The Gaza Strip: Critical Effects of the Occupation. In N. Aruri (Ed.) Occupation: Israel over Palestine. Belmont, MA: AAUG Press, pp. 249-296.

${ }^{100}$ Ibid., p. 277.
} 
With the lack of economic development within the territories, an increasing number of Palestinians joined the labor force in Israel. While the payment there was much higher than any potential earnings in the OT, the average income for Palestinians was still merely one sixth of that of an Israeli worker. At the same time, a substantial amount of funding was available for Jewish people wishing to settle in the West Bank and Gaza. As one settler confirmed:
All one needs to do in order to qualify for such a sum is to decide that one wants to join a settlement. Various institutions will then look after all one's needs: a truck is sent to help one move; one is given a place to live and a plot of land as well as other means of production worth many millions [of lira]. ${ }^{101}$

This indicates that the Palestinian territories have served as a crucial investment opportunity for over-accumulated capital while at the same time allowing for the pursuit of imperialist objectives: whereas Palestinian farmers and entrepreneurs were exploited, Jewish settlers benefited from seemingly unlimited capital inflows. This dialectical relation of contradiction furthers our understanding of the increasing frustration among the Palestinian population in the OT that would eventually lead to the first intifada in 1987.

Overall, the permit regime was designed to make the occupation "invisible" as to avoid the formation of any meaningful, organized resistance from the Palestinians. For that reason, the military administration only acted at the higher levels, whereas Arab officials remained in their positions at municipal and local levels. Furthermore, Israel established an official Civil Administration over the Palestinian Territories in 1981. What was supposed to be an end to the military rule was in reality merely a change in names, creating an illusion of normal social relations which served as a disguise for increasingly coercive measures of control. ${ }^{102}$ Thus the

\footnotetext{
${ }^{101}$ Qtd. in Graham-Brown, op. cit., p. 306.

102 Nakhleh, K. (2004). The Myth of Palestinian Development: Political Aid and Sustainable Deceit. Jerusalem: PASSIA, p. 146. See also Gordon, op. cit., p. 110.
} 
Civil Administration provided a newly consolidated form of power, or scalar fix, with the objective to enhance the semblance of normality. Yet, the forms of control mechanisms established under military rule did not change with the new administration, merely the way they were deployed.

Despite these efforts to 'normalization', Israel failed to suppress resistance to the oppressive occupation all together. Since the 1967 war, the relationship between Israel and the Palestinians in the OT has been defined by the mutual reinforcement of the two social factors occupation and resistance. To the extent that the former has shaped the latter, the resistance also defined the mechanisms and methods of Israeli military rule.

That the Civil Administration still had a tight grip on the social structure of the OT can be seen in an examination of foreign efforts to foster socio-economic development in Palestine. In his detailed analysis of the most significant development agency for Palestine active during the pre-Oslo years - the Geneva-based Welfare Association (WA) - Palestinian scholar and development consultant Khalil Nakhleh reveals numerous obstacles to genuine, sustainable development and empowerment of the indigenous Palestinians. As all money to be allocated to the Palestinian economy was controlled by Israeli rule, efforts of foreign 'developmental' intervention were greatly restricted. Moreover, while the WA succeeded in establishing a considerable development fund, the achievement of genuine development was greatly exacerbated, as every single project required a priori approval and cooperation from the military authorities. $^{103}$

Another great impediment to development was the growing corruption, both among founding members of the WA, most of who were Palestinian businessmen, and within the various factions of the PLO which had become increasingly institutionalized within the OT ${ }^{103}$ Ibid. 
during the first intifada. Albeit clear principles for a genuine development had been established, they were not internalized by the founding members, and the actual intervention on the ground gave a different picture from that stated in the objectives. Rather than providing aid to those projects in need, the corrupted leadership of the WA often allocated funds to befriended entrepreneurs in the OT, hoping to establish a good position for themselves for the expected Palestinian autonomy.

\subsection{The Oslo 'Peace Process' - A Peace to End all Peace?}

The following analysis will not only expose the Oslo Accord as a contradiction in itself, but as a culmination of all four types of relations used in the dialectical method, showing that the treaty and its ensuing negotiations and agreements did not bring the promised peace, but rather intensified the conflict.

The Israeli-Palestinian Declaration of Principles signed on 13 September 1993 was the response to six years of brutal violence that had evolved since the outbreak of the first Intifada in 1987. In this declaration, the two sides, i.e. the State of Israel and the Palestinian delegation, representing the Palestinian people, agreed "that it is time to put an end to decades of confrontation and conflict." They further pledged to

recognize their mutual legitimate and political rights, and strive to live in peaceful coexistence and mutual dignity and security and achieve a just, lasting and comprehensive peace settlement and historic reconciliation through the agreed political process. ${ }^{104}$

What came to be known as the Oslo Accord contained big words and great ideas, which according to Arafat marked "a new era in the history of the Middle East"105 and, at the time, may

\footnotetext{
${ }^{104}$ Israeli-Palestinian Declaration of Principles, qtd. in Khan, Z. (1998). Palestine Documents. Pharos Media \& Publishing (P) Ltd: New Dehli, p. 501.

${ }^{105}$ Letter from Arafat to Rabin, 9 September 1993, qtd. in Khan, op. cit., p. 513.
} 
have sounded rather promising to some. Yet a closer look at the Accord's individual articles and annexes would have immediately raised suspicion. In hindsight, the agreement may doubtlessly be judged as a failure.

Indeed, scholars have argued that the Oslo Accord, along with its ensuing agreements, was bound to fail from the very beginning of the negotiations, primarily due to the differential treatment of two supposedly equal negotiation partners. On the one hand, power games between the external PLO and the negotiators from the West Bank and Gaza significantly weakened the Palestinian party already during the preparatory stage. In stark contrast to Israel, the Palestinian negotiators went to the talks lacking the bare minimum of preparation: neither were they in possession of maps of their own, nor did they have any detailed knowledge or a firm commitment to "principle and justice." 106 Consequently, the negotiations were held primarily on Israeli terms, for the PLO was eager to make concessions to Israel in order to ensure their own position in power. Failing to understand the political and historical context and significance of the negotiations, the PLO leaders entirely ignored the demands of the Palestinian people, most importantly a sovereign state and the rights for those hundreds of thousands of refugees and diaspora in Europe and the US to return to their homes. ${ }^{107}$

In adherence to a Kissinger memorandum issued almost two decades before, the Oslo agreement embraced a 'step-by-step' strategy, promising a Palestinian statehood only in 'final status negotiations', which were to come into existence only after certain conditions were met, including the Israeli withdrawal from most of the Palestinian areas. Thus, the crucial issue of sovereignty was deferred to an undetermined point in time - which, indeed, has yet to materialize. What the Palestinians received instead was an 'autonomy' regime of the Palestinian

\footnotetext{
${ }^{106}$ Said, End of the Peace Process, op. cit., p. 14.

${ }^{107}$ Ibid., p. 153.
} 
Authority under which Yassir Arafat succeeded to establish a repressive one-man rule with a corrupt, incompetent bureaucracy considered by Edward Said "worse than the cooperation with Israel" established to eliminate 'opponents' of the peace process. ${ }^{108}$ The Israeli journalist Danny Rubinstein compared the autonomy granted to the Palestinians with the situation "in a POW camp, where the prisoners are 'autonomous' to cook their meals without interference and to organize cultural events." ${ }^{109}$ In other words, whatever little self-rule was transferred to the PLO, the actual state of affairs was still under final supervision by Israel.

In addition to the PLO's abuse of its position as the representative of the Palestinian people, the agreement has been continuously violated by Israel. Not only was the agreed schedule for redeployment of Israeli troops in the West Bank delayed, it was in fact never completed. To this day Israel remains in control of the entry points to Gaza and the West Bank as well as the villages near the Green Line deemed for military or state use. Moreover, figure 6 shows how the West Bank remains highly fragmented through the numerous closures (i.e. checkpoints, road gates, earth walls etc.) maintained by Israel. ${ }^{110}$ As Israeli historian Ilan Pappe points out, the Zionist state continues to rule with "brutality and callousness" over what amounts to more than $50 \%$ of the land. ${ }^{111}$

\footnotetext{
${ }^{108}$ Ibid., op. cit., pp. 18 and 65.

${ }^{109}$ Danny Rubinstein, qtd. in Chomsky, op. cit., p. 535.

${ }^{110}$ See also Appendix B for a case study of a Palestinian village in the West Bank.

${ }^{111}$ Pappe, History of Palestine, op. cit., p. 244.
} 


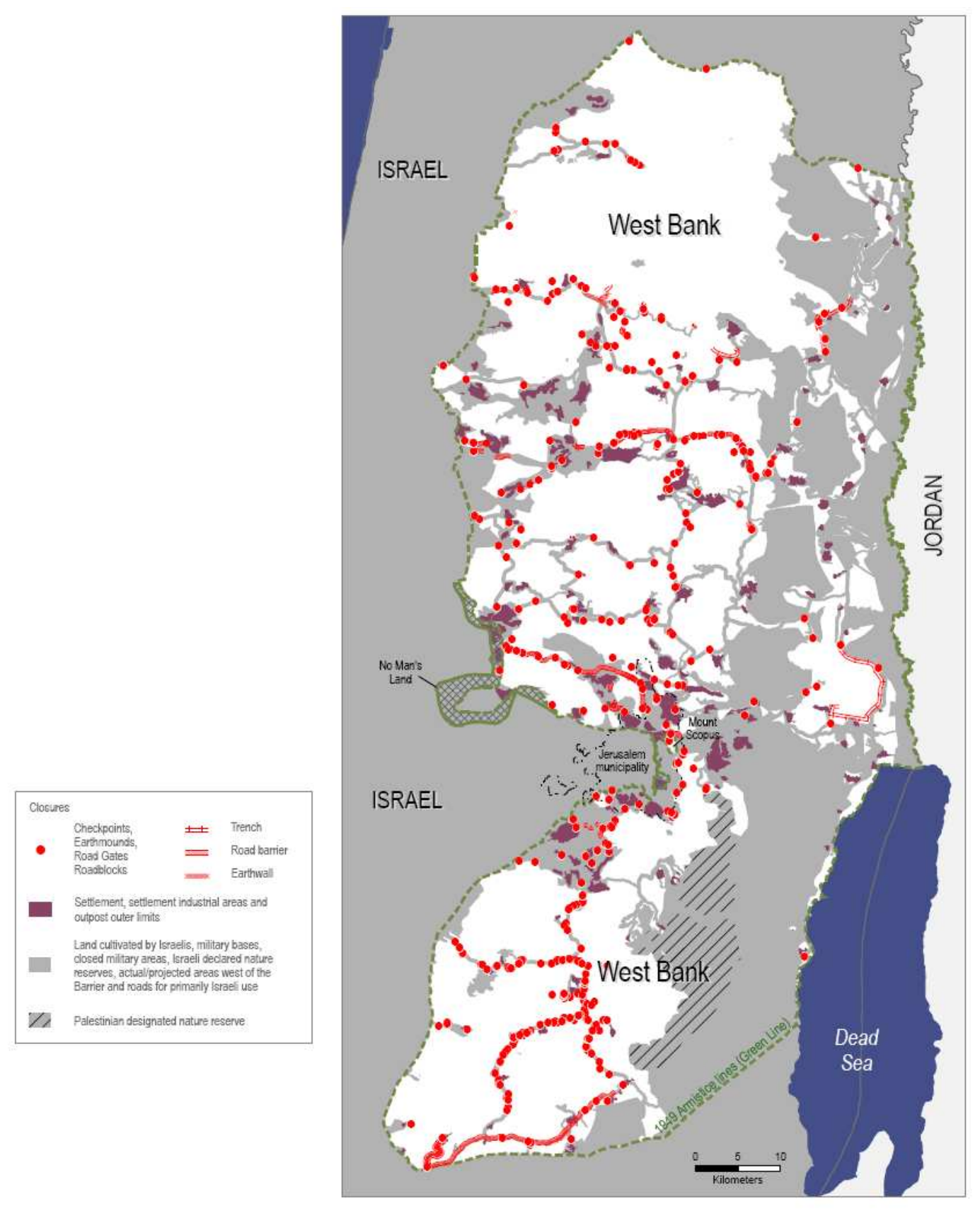

Figure 6: Location of closures in the West Bank. (Source: OCHA)

Such violations were in fact facilitated by the vagueness of the language in the Oslo agreement which, by and large, merely stipulated further negotiations and agreements, rather than providing clear assignments for both parties. Thus, the provision that the status of the West Bank and Gaza should not be changed notwithstanding, the Accord does not explicitly prohibit 
the further spread of settlements in the territories. Within the decade following the first Oslo agreement in 1993, the number of Jewish settlers in the West Bank nearly doubled, "creating an imagined map of a Jewish West Bank above, in more than one sense, the Palestinian one."112

The Jewish settlers literally surrounded the Palestinians from all sides, with tunnels below and highways above them. In their function as 'bargaining chips' in the peace negotiations, the location of the Jewish settlements have had a significant impact on the proposed land distribution between Israel and the aspired Palestinian state, whereby some 161 Palestinian enclaves in Areas A (Palestinian cities) and B (Palestinian villages) are surrounded by Area C containing all the Jewish settlements and Israeli military areas. ${ }^{113}$ Figure 7 shows the division of the West Bank into Areas A, B and C as discussed during Oslo II negotiations, 1995. The map clearly shows that, at that time most of the West Bank territory was still under Israeli control. The Israeli settlements, roads and military areas grossly disrupted the urban and rural areas, preventing the consolidation of a structured coherence within a future Palestinian state.

At the Camp David II negotiations in July 2000, Ehud Barak made a "generous offer" to the Palestinians, which proposed to incorporate a significant area of the West Bank - in part temporarily and in part permanently - into the state of Israel. The remaining Palestinian land was to be even more fragmented through the separation into three areas that have been described as 'Bantustans', emphasizing the similarities to the geopolitical conditions of South Africa under the Apartheid regime. ${ }^{114}$ It should be no surprise that Arafat rejected Barak's offer, which allowed Israelis to "live in continuous space" where they "enjoy free movement" while

\footnotetext{
${ }^{112}$ Falah, Shrinking of Arab Lands, op. cit., p. 196; Pappe, History of Palestine, op. cit., p. 243.

113 Reuveny, op. cit., p. 360.

${ }^{114}$ Said, End of the Peace Process, op. cit., p. 15; see also Pappe, History of Palestine, op. cit.,; Falah, Shrinking of Arab Lands, op. cit., and Reuveny, op. cit.,.
} 
"Palestinians are compelled to reside in an array of newly generated enclaves." 115 The second intifada which followed the failed negotiations was thus a clear reflection of how far away the talks had moved from the realities of the events in 1948 and the possibility of a sovereign Palestinian state, which had been promised more than 50 years before.

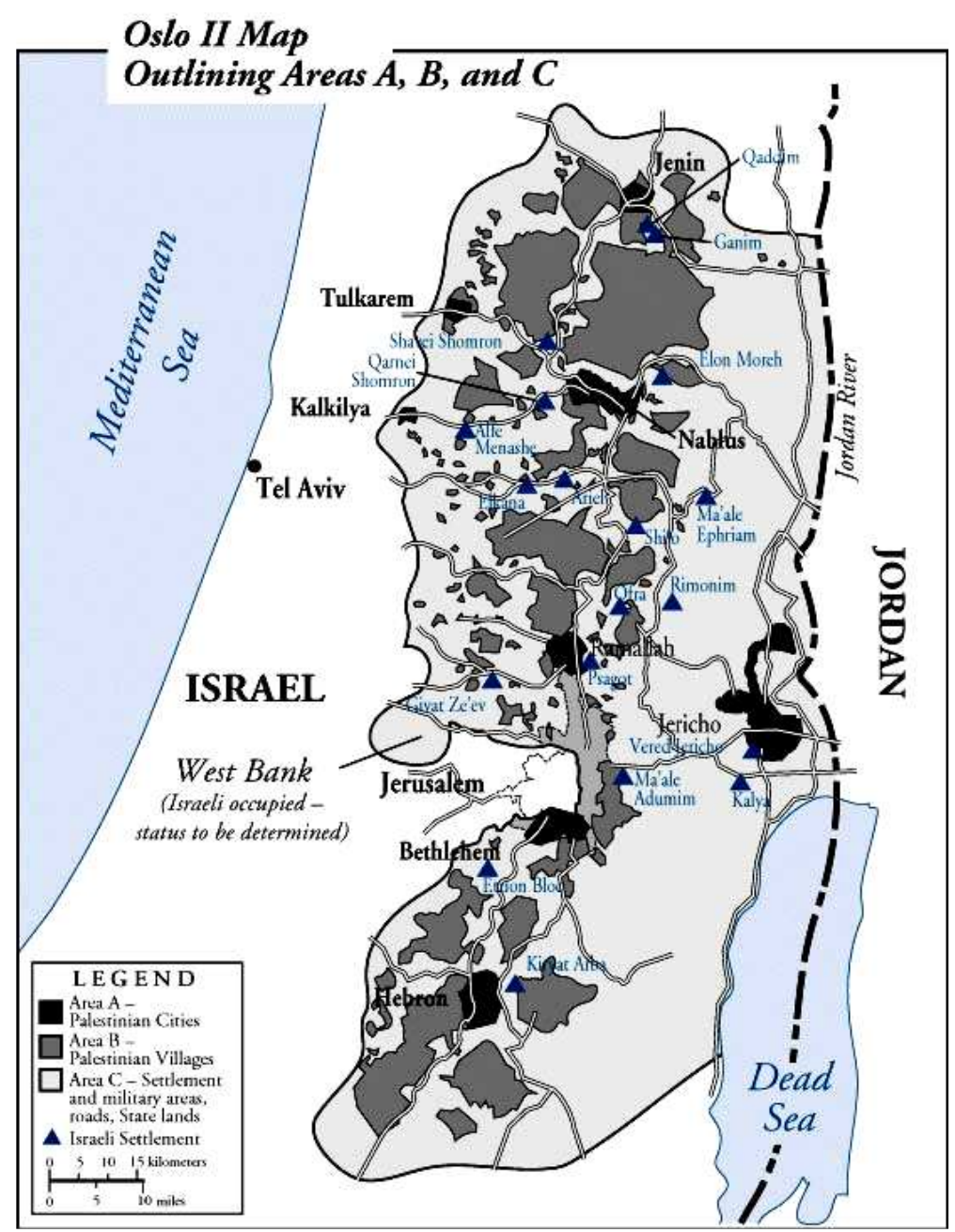

Figure 7: Oslo II Map (Source: Palestine Center)

\footnotetext{
${ }^{115}$ Falah, Shrinking of Arab Lands, op. cit., p. 193.
} 
Another dimension of the 'peace process' was the opening up of new channels for increased capital inflow to foster economic development through the international community, a process which Khalil Nakhleh exposed as a myth. ${ }^{116}$ While the Oslo accords allowed and encouraged big monetary investments in the Palestinian Territories, no genuine development strategy was developed, especially from the EU, the largest donor of Palestinian aid in the postOslo years. Moreover, crucial technical assistance for development projects was outsourced to what Nakhleh termed "New Mercenaries" instead of incorporating the indigenous population, thus rendering the latter the "weakest political element", "non-participant actors" on whom foreign, ill-conceived policies were imposed. ${ }^{117}$

Finally, whatever little structural and developmental improvement was achieved after the Oslo agreements, it was completely reversed with the re-occupation of the OT by Israel in 2002 . Witnessing the destruction of houses with bulldozers and the imposition of new curfews accompanied by continuous gunfire in Ramallah, Nakhleh described the irony of the events:

Each time some of the tanks and armored personnel carriers rumbled down the road in which I live, visible and audible from my office window, I would continue, calmly and coolly, to analyze the process of 'developing' and 'un-developing' Palestine.

The well formulated objectives for developing not only a healthy Palestinian economy but also a coherent, self-confident society were nothing but rhetoric in the sense of Orwellian doublethink, for the end result of immeasurable efforts and millions of aid was complete undevelopment of an entire people. As Nakhleh concludes: "This is a process of un-developing

\footnotetext{
${ }^{116}$ Nakhleh, Myth of Development, op. cit.

${ }^{117}$ Ibid., pp. 140/1 and 191/2.
} 
Palestinian society, undermining and dismantling any potentially viable Palestinian institution." 118

Indeed, some scholars consider the Oslo accords and the ensuing agreements as an official consent to Israeli occupation - a "consolidation of Israel's territorial gains in Gaza and the West Bank." ${ }^{119}$ At the same time, Israel received international credit for making 'peace' while continuing its occupation. The socio-spatial inequality between Israel and Palestine could not be more clear.

While Oslo was supposedly the hallmark of the peace negotiations, the so-called 'process' remained rather stagnant and never reached its goal. As none of its objectives were achieved, the 'peace process' became an empty phrase without meaning. Yet, it remains firmly in place. As if its existence was appeasing the Palestinians, the never-ending 'peace process' continues, with renewed efforts whenever it seems in Americas or Israel's interest. The 'process' is "reinvented all the time ... [and] America thinks ... as long as there is a 'process', God is in heaven" noted Palestinian scholar and activist Hanan Ashrawi. ${ }^{120}$

Contrary to its promise of a solution to the Palestine-Israel conflict and the prospect of bringing peace to the Middle East, the Oslo Accord and its follow-up agreements had a further consolidating effect for the status quo. Said noted that, albeit acknowledging its injustice, many Palestinian and Arab scholars and intellectuals, as well as those supportive of Palestine, have argued that the agreement between Israel and the PLO - for which Arafat shared the Peace Nobel

\footnotetext{
${ }^{118}$ Ibid., pp. 172/3.

${ }^{119}$ Said, End of the Peace Process, op. cit., p. 154; see also Chomsky, op. cit.

${ }^{120}$ Qtd. in Fisk, R. (2006). The Great War for Civilization: The Conquest of the Middle East. London: Harper Perennial, p. 554.
} 
Prize with Rabin and Peres - should be accepted as a "reality" and that practical proposals should be made as to how to "deal" with the contemporary situation. ${ }^{121}$

Oslo also marked the beginning of the PLO's - and later Fatah's - cooperation with Israel, bringing the Islamic resistance movement, Hamas, to the forefront of Palestinian opposition. Taking the place of PLO, Hamas has refused to recognize Israel and takes a strong stand in their demands for Palestinian sovereignty. Despite immense criticism of Hamas' position, the Israeli journalist, Danny Rubinstein evaluated the situation as follows:

\footnotetext{
If you add to this the growth of settlements in Samaria, Ariel, the suburbs of Ramallah, in an expanded Gush Etzion and Mount Hebron, the Israeli message becomes unequivocal: You Palestinians have no chance. You recognized Israel and what you received in return was the liquidation of your national hopes. So why should Hamas repeat the same recognition whose results we have already seen $?^{122}$
}

\section{Conclusion}

This chapter examined the formation of various, select policies, treaties and legislative acts which, in their function as scalar fix, have played a significant part in shaping Palestinian space and consolidating the dispossession of the Palestinian people since the first immigration waves of Jewish settlers driven by Zionism at the end of the $19^{\text {th }}$ century. In that sense, combining all the aspects discussed in the individual sections as internal relations of the act of dispossession - in itself a factor within the overall process of uneven development - allows us to realize the extent of the rise of Zionist power and expose the Zionist/Israeli leadership as "those who steal the commons from under the goose." It further helps us to put Palestinian resistance, in

\footnotetext{
${ }^{121}$ Said, End of the Peace Process, op. cit., p. 68.

122 Rubinstein, D. (2006, September 26). Why Recognize Israel? Haaretz.
} 
form of the two intifadas or handmade rockets fired from Gaza into Israel, into perspective and to begin to gain understanding of the motivation for such acts of violence.

Yet, this dialectical analysis needs to be taken further and investigate the workings 'behind the scenes' which allow the policy making examined in this chapter to be established. In order to illuminate these processes, the following chapter will analyze the scalar fix of networking, first by revisiting two key events leading to the creation of the State of Israel: the Balfour Declaration and the UN Partition Plan of 1947, and second by examining the 'special relationship' between Israel and the US. 


\section{CHAPTER 5:}

\section{CONSOLIDATION OF POWER THROUGH NETWORKING}

\section{Introduction}

This chapter illustrates how the establishment of social networks and close relationships often based on economic, religious or ideological grounds - facilitates the consolidation of power, i.e. the scalar fix of dispossession. Given the extent of influence that networking activities exercise in determining the flow of social activities as well as finance capital, I have argued in chapter 3.4 that networking in itself constitutes a function of scalar fix. As will be shown in this chapter, the identification of networks as a form of scalar fix is essential to the extent that the processes of legislation and policy making discussed in the previous chapter were largely driven by the collaboration of individuals and groups pursuing common interests of capitalistimperialist nature. It is the very coherence among the ruling classes which serves as facilitator of dispossession and oppression which otherwise would be easy to break up and resist.

\subsection{Pre-State Efforts}

Some of the major treaties and doctrines discussed in the previous chapter came about through workings 'behind the scenes'. In order to illuminate these processes we will revisit two key events leading to the creation of the State of Israel: the Balfour Declaration and the UN Partition Plan of 1947.

We have already noted that the formation of the Balfour Declaration was considerably shaped by temporal components. However, full understanding of the issuance of the document requires a look at the networking mechanism among the British pro-Zionist Jewry and the ties it 
established with influential politicians at the time. The point of origin of this Jewish network was Manchester, where Zionist leader Chaim Weizmann (later to be first President of the State of Israel) was employed as a lecturer in bio-chemistry at the University of Manchester. Not only was Manchester home to a great part of the British Jewry but also counted foreign secretary Lord Balfour and Prime Minister Lloyd George among its constituents.

Weizmann established a support group of influential Jews, starting with the Jewish banking elite, the Rothschilds, who controlled not only Britain but virtually all Europe financially and politically, being largely involved in capitalist-imperial ventures in Asia as well as South America. ${ }^{123}$ While the majority of the Rothschild family had been explicitly anti-Zionist in the late $19^{\text {th }}$ century, the events of WWI brought them much closer to the Zionist enterprise. Weizmann was thus able to secure the backing of Sir Walter Rothschild, heir of the Rothschild's quasi-monarchical status among British Jewry, who introduced him to influential figures in British politics - the potential supporters of the Zionist project. Among them was Sir Herbert Samuel, who had been attracted to the Zionist idea even before the war, and who was later to become the first High Commissioner for Palestine. In a memorandum circulated in March 1915, Samuel laid out his thesis for a British protectorate in Palestine, arguing that British control over the area would be the best possible solution in the Empire's interest:

Its establishment would be a safeguard to Egypt [...] It is hoped that under British rule facilities would be given to Jewish organizations to purchase land, to found colonies, to establish educational and religious institutions, and to co-operate in the economic development of the country, and that Jewish immigration, carefully regulated, would be given preference, so that in course of time the Jewish inhabitants, grown into a majority and settle in the land, may be conceded such degree of self-government as the conditions of that day might justify....

\footnotetext{
${ }^{123}$ For an insightful account on the Rothschild banking family see Ferguson, N. (2000). The House of Rothschild: The World's Banker 1849-1999. New York: Penguin Books.
} 
The course which is advocated would win for England the gratitude of the Jews throughout the world In the United States, where they number about 2,000,000, and in all the other lands where they are scattered, they would form a body of opinion whose bias [...] would be favourable to the British Empire. $^{124}$

In addition to his relations with the Rothschilds and other members of the elite, Weizmann's work as a chemist, in particular his research on the mass production of acetone, made him an invaluable asset to the British military, bringing him into close contact with war Prime Minister Lloyd George and providing the opportunity to introduce the Zionist project to the British government. ${ }^{125}$ Moreover, his contributions to British war strategy helped Weizmann establish close connections with and gain substantial support from influential members of government such as General Jan Christian Smuts, who in 1917 was sent as the 'Special Delegate from South Africa' to the War Cabinet in London, and who, not surprisingly, supported a policy for Palestine similar to the colonial regime in South Africa.

The UNGA Partition Plan from 1947 was noted as the second decisive document that enabled the power consolidation leading to the State of Israel. It is thus worth examining the influence of Zionist efforts in the background. The idea of partitioning the land to establish an independent Jewish and Palestinian state had existed for more than a decade and had been recommended by several foreign committees which, in response to the growing violence, were established to examine the situation in Palestine. Figure 8 shows the recommendation of the Royal Peel Commission, which in 1937 proposed to allocate less than one fifth of Palestine to a Jewish state, leaving the rest of the area to the Palestinians. Comparing the Peel proposal to the UNGA Partition Plan ten years later (see figure 8), it is obvious that the area assigned to the Jews

\footnotetext{
${ }^{124}$ Stevens, R. (1971) Zionism as a Phase of Western Imperialism. In I. Abu-Loghod (Ed.) The Transformation of Palestine: Essays on the Origin and Development of the Arab-Israeli Conflict. Evanston: Northwestern University Press, p. 44.

${ }^{125}$ Stein, L. (1961). The Balfour Declaration. New York: Schuster and Schuster, p. 107.
} 
had grown considerably. Scholars suggest that the commissions' increasingly favourable attitude towards the Jews - neglecting the Palestinians' refusal of partition of their homeland - were the result of immense Zionist lobbying efforts in Britain and the US, coupled with the manipulative interference with the investigations conducted by officials from the committees.

Towards the end of World War II, examination did not only involve the situation in Palestine but also that of the DP camps in Europe, a fact which the Zionists used to their advantage. When the Anglo-American Committee toured the DP centers in 1946, Zionist officials organized the visit and thus ensured that only those Jews in favor of establishing a Jewish state were interviewed by the committee. Similarly, travels around Palestine were influenced by the Haganah, presenting the highly developed Jewish settlements and their beneficial impact on the backward Palestinian Arabs. This was backed up with a thousand-page report issued by the Jewish Agency which portrayed the Zionists as representatives of "enlightenment and progress". The one-sided representation of Palestinian space left no room for doubt that the Zionists were not only beneficial to the development of Palestine and its indigenous population but indeed indispensable. The Zionists' efforts had such an immense impact on the committee members that even those who had been skeptical at the outset of the investigation became staunch supporters of the Zionist cause. ${ }^{126}$

The investigations by UNSCOP (United Nations Special Committee on Palestine), were handled in a similar manner, so that its officials - who knew little about Middle East affairs and had visited Palestine only briefly - were more impressed by the tragedy of the Holocaust in Germany than the Palestinians' fear of an outbreak of Zionist violence and takeover of their

\footnotetext{
${ }^{126}$ Morris, Righteous Victims, op. cit., pp. 177/8.
} 
land. ${ }^{127}$ Thus, due to the splendid presentation and constant pressure by the Zionists and the lack of any meaningful counter-measures by the disunited Arabs, UNSCOP proposed a division plan which was to lay the foundation for the Jewish state.
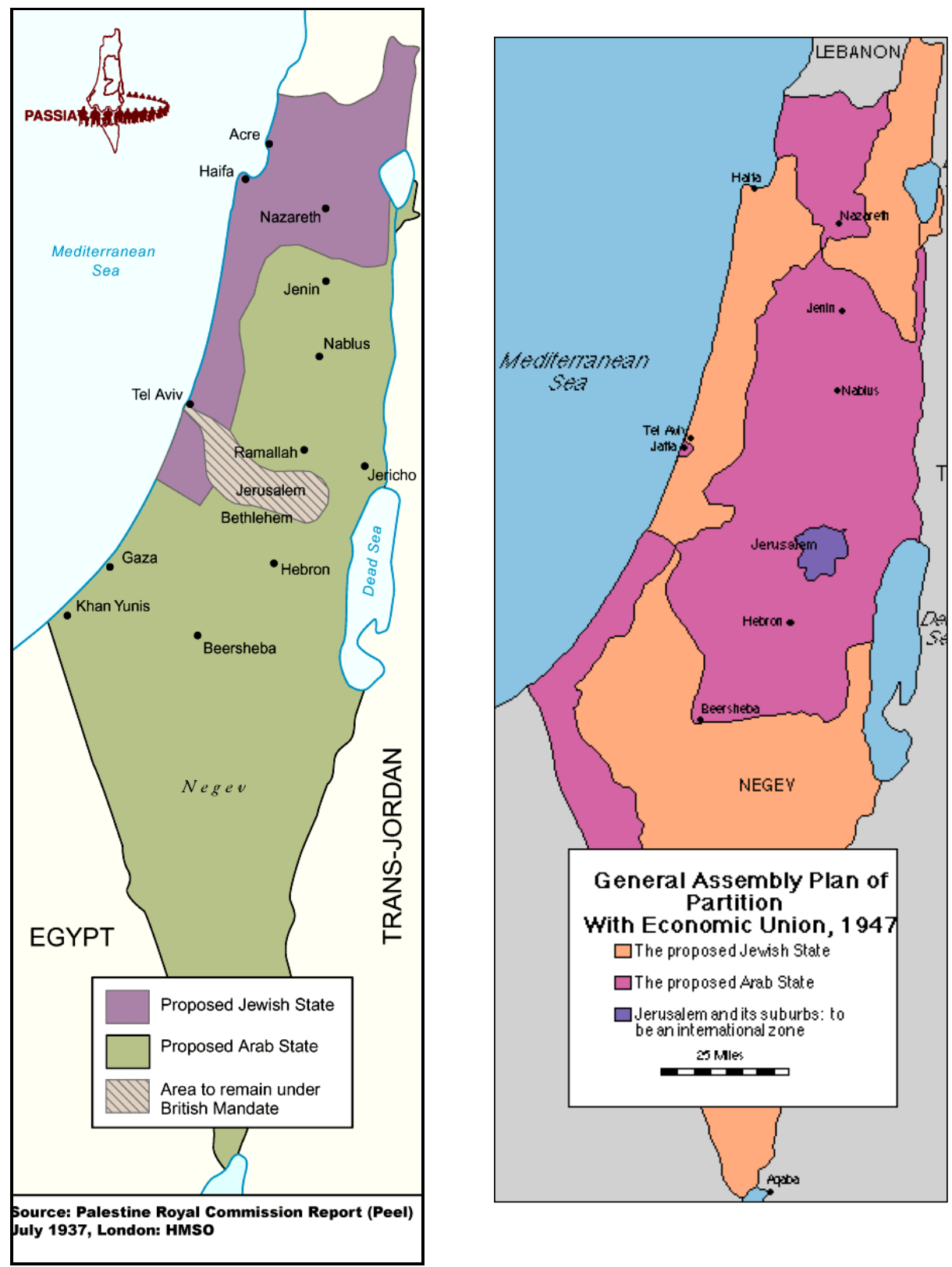

Figure 8: Partition Plan of the Peel Commission, 1937(left) in comparison to the UNGA Partition Plan, 1947 (right) (Sources: PASSIA; MideastWeb)

\footnotetext{
${ }^{127}$ Morris (p. 182) reports that during UNSCOP's visit of Palestine in May 1947, the Zionists even bugged the committee's rooms, thus being able to overhear all secret discussions.
} 
This brief analysis strongly suggests that the Zionist networking efforts played a significant part in shaping the events that led to the establishment of the State of Israel - to the extent that the legislation and policies might not have come about had it not been for the Zionist influence. Whereas the scope of this thesis only allows for a basic introduction of this form of scalar fix, a more-in depth examination is necessary to expose the full extent and impact of the power of networking regarding the creation of the Zionist state. The following section will examine another angle of the Zionist network and its function as scalar fix: the Zionist power configuration in the US.

\subsection{The "Special Relationship" Between the US and Israel}

It is not possible to discuss the US imperial system without drawing attention to the anomalous position that Israel holds within it. James Petras ${ }^{128}$

At the beginning of World War I, the majority of American Jews did not support Zionism. This was to change, however, as the Balfour Declaration gave legitimacy to the plan of Israeli statehood in Palestine. The Declaration enabled Zionists to "tap the funds collected by ... non-Zionist organizations" and thus helped the movement to expand its influence on the Jewish population. ${ }^{129}$ The American government, however, showed little interest in Palestine - a position which was not to change until Israel's war in 1967.

Since then, a close relationship has emerged between the US and Israel, not only economically, but also on a political scale. As I have argued in chapter 3, the 1970s saw a shift in US policy towards a neo-liberal politics that emphasized the accumulation of finance capital.

\footnotetext{
${ }^{128}$ Petras, J. (2007) Rulers and Ruled in the US Empire: Bankers, Zionists, Militants. Atlanta, GA: Clarity Press, p. 121.

${ }^{129}$ Stork and Rose, op. cit., p. 43.
} 
Since the beginning of that decade the US began to take advantage of Israel's 'advanced' state of development, being "the only developed capitalist country in the Middle East." ${ }^{\text {"130 }}$ In line with its containment policy against the Soviet Union, the US supported the Jewish state's objective to achieve regional economic dominance through massive loans and grants. The resulting relationship of Israel with its surrounding Arab neighbors has been described as "classical colonial", with the occupied Palestinian territories, as well as Syria and Lebanon supplying capital and skilled labor and cheap agricultural products to Israel.

The imperial interests of both the US and Israel are a major defining factor of the relationship between the two countries. This is reflected not only in the capital logic of power (i.e. the unparalleled financial assistance provided by the US), but also in the territorial logic or, more plainly, the military relationship. While Israel has enjoyed a massive transfer of arms and weapons from the US, it has in return supplied munitions and military services to US-allies in the Middle East region as well as in Africa. With the help of aid from the US, Israel has assisted in training soldiers in former Zaire, Ethiopia and South Africa. Thus, the US and Israel share in their imperialist objectives, not only to gain influence on a regional but also on a wider scale.

This has also affected peace negotiations in the Middle East, which the US often manipulates to Israel's advantage. In the 1973 war, it purposefully 'prolonged' diplomatic efforts as to "delay the Security Council in order to give Israel 72 more hours to fight." time, the US position was not to merely provide unconditional support to Israel, as the increasing need for oil also determined America's "interest in the 130 million Arabs that sit athwart the world's oil supplies."132 Peace negotiations between Israel and Egypt throughout the 1970s under the initiative of US Secretary of State, Henry Kissinger, were thus complicated; and the Jewish

\footnotetext{
${ }^{130}$ Rubin, B. (1973). America's Mid-East Policy: A Marxist Perspective. Journal of Palestine Studies, 2 (3), p. 55.

${ }^{131}$ Kissinger Memorandum. (1981). To Isolate the Palestinians. MERIP Reports, 96, p. 25.

132 Ibid.
} 
state agreed to give up the Sinai Peninsula only after extensive assurances and repeated written agreements were made, stating that the US would compensate Israel for its abandonment of the Egyptian oil fields and guarantee its oil supply. ${ }^{133}$ These concessions were accompanied by guarantees to aid Israeli defense through increased arms supplies, as well as loans and grants, averaging \$2.2 billion per year between 1976 and $1980 .{ }^{134}$ After the initial failure of Kissinger's shuttle diplomacy, the US deliberately decided to implement a "step-by-step" strategy towards a peace process where Israel would not be forced to discuss critical issues such as borders and the Palestinian right to return. This approach has been maintained, leading ultimately to the failure of the Oslo Accord (see chapter 4.6).

Israel's 'special' relationship with the US has given the Jewish state a jester's license to ignore international law and condemnation of its policies and remain firm in its discriminatory position towards the Palestinians. Numerous UN resolutions - most famously Resolution 242 have been passed to outlaw Israel's longstanding occupation of Palestinian territory and its indiscriminate warfare against Palestinians and Lebanese - to no avail. Resolutions by the Security Council are either vetoed by the US or outright rejected by Israel. A UN General Assembly resolution on 13 November 2006 condemning the massacre of Beit Hanoun and calling for an investigation was also ignored by the Jewish state, which instead continued its assault on the Palestinian people. ${ }^{135}$ Even proposals for peace negotiations advanced by Hamas as early as 2005 were rejected on grounds that Israel does not negotiate with 'terrorist organizations'. Instead, it responded with an economic blockade on the Gaza strip and several airstrikes in 2006, leading to the death of some 400 Palestinians, more than half of them civilians. The United States also stood firm with Israel in its rebuff of a proposal by UK Prime

\footnotetext{
${ }^{133}$ The Abu Rudeis oilfields in the Sinai had supplied 55\% of Israel's oil needs.

${ }^{134}$ Bahbah, B. (1982). The United States and Israel's Energy Security. Journal of Palestine Studies, 11 (2), p. 129.

${ }^{135}$ Petras, op. cit., p. 115.
} 
Minister Tony Blair for a Middle East conference which was to bring all parties to the table, including Israel and Palestine, Syria, Iran and Iraq.

The 'special' relationship, however, is not just defined by America's unconditional support for Israel and the latter's total dependence on the former. Rather a mutual dependence has evolved which allows Israel at times even to dictate to the US. Nor is this a recent phenomenon, as the circumstances of the attack on the USS Liberty by Israeli forces at the onset of the war in June 1967 show. Despite great efforts from the Pentagon and Defense Secretary Robert McNamara to cover up the facts and silence the surviving crew members, evidence has shown that the attack by Israeli fighter planes was not an accident at all. The Israelis knew very well before the assault that the ship they were about to attack was under American flag. Evidence even suggests that the attack was planned beforehand and ordered directly by then Israeli Defense Minister Moshe Dayan. While this was very well known to the Americans, they agreed to cover up the deliberate attack on one of their ships. As Jeffrey St. Clair concludes, "the IDF's strike on the Liberty served to weld the US and Israel together, in a kind of political and military embrace." Little wonder then that Palestinians see the Israeli attacks on their townships and villages as a "joint operation, with the Pentagon as a hidden partner.",136

In recent years, Israel's position also allowed the Jewish lobby, and if necessary the Jewish state itself, to interfere in US foreign policy with Iraq and Iran. When the US government mandated the Baker commission to examine and evaluate the situation in Iraq, it took Israeli President Olmert's direct intervention to dismiss the resulting recommendations to engage in diplomatic talks with Iran and Syria over Iraq. While the Baker report was published in a rather friendly environment, and was thus expected to be incorporated in US foreign policy making, it

\footnotetext{
${ }^{136}$ St. Clair, in Cockburn, A. and J. St. Clair, (Eds.) (2003) The Politics of Anti-Semitism. Petrolia and Oakland, CA: CounterPunch and AK Press, op. cit., p. 97.
} 
failed to have any positive impact on America's position towards Iran and Syria. On the contrary, as relations between the US and Iran became increasingly aggravated over issues of nuclear proliferation and intervention in Iraq, it was mainly the Jewish lobby in the US which advocated a war in Iran. The lobby perpetually distributed war propaganda dismissing not only Iran's claim of pursuing a peaceful nuclear research program but also affirmative findings by the IAEA commission. ${ }^{137}$

This somewhat curious behavior by a rather small and young state which is highly dependent on foreign financial and military aid, merits a closer look at the supporting network that operates in the US - the Zionist power configuration (ZPC), to use James Petras' term. The ZPC includes 51 national Jewish organizations (including the America-Israel Public Affairs Committee, or AIPAC, and the Anti-Defamation League) under the umbrella of the Conference of Presidents of the Major American Jewish Organizations (CPMAJO) as well as several hundred Jewish Federations on a regional and local scale. Additional financial support comes from Jewish millionaire (and billionaire) donors, but also a great number of political action committees, whose names do not indicate any connection to Israel but which raise funds for the Jewish state.

Even more difficult to pinpoint and to measure is the impact of an array of cultural, "fanatical" activists who reprimand and counter anything and anybody critical of Israel. ${ }^{138}$ That said, the following example of 'activism' is illustrative. In April 2008, it was discovered that a pro-Israel activist group, CAMERA (Committee for Accuracy in Middle East Reporting in America), had drawn up a plan to infiltrate Wikipedia with its own people who - once being established as neutral administrators - would change articles relating to the Palestinian-Israeli

\footnotetext{
${ }^{137}$ Petras, op. cit., p. $105 \mathrm{ff}$.

${ }^{138}$ Ibid., pp. 122 and 132.
} 
conflict in favor of the Zionist narrative. The plan is said to have been abolished after it was uncovered. $^{139}$

With this tight network in place, the sway of the ZPC goes far beyond the lobbying activities of AIPAC and the like. Petras identified a number of major, Washington-based think tanks, including the American Enterprise Institute and the Project for the New American Century, which frequently publish position papers, editorials and opinion pieces in prestigious newspapers, and whose political analysts and Middle East 'experts' appear regularly on TV news programs and political debates, presenting a pro-Israel point of view. ${ }^{140}$

Furthermore, the ZPC asserts direct influence on US policy making. Not only is the network's political pressure able to ensure up to 98 percent within the US Congress to support any legislation in favor of Israel, it also controls - directly or indirectly - the most influential positions in the US administration. Close examination reveals what has been termed a "dual loyalty", i.e. the relationship between the above-mentioned think tanks and US government officials. Two of the most senior officials in the US State Department under the Clinton administration, who were responsible for the Palestinian-Israeli peace process, had held the position of director for a pro-Israeli think tank either before or after becoming a US government official. ${ }^{141}$ The already intimate ties between the pro-Israel activists and the US government intensified significantly under the Bush administration, where ever more "Israeli loyalists" entered the government on all levels. ${ }^{142}$ During the first term of the Bush presidency, the White House was influenced, among others, by speechwriter David Frum, Special Assistant Elliot

\footnotetext{
${ }^{139}$ The Electronic Intifada. (2008, April 24). Pro-Israel group's plan to rewrite history on Wikipedia. Centre for Research on Globalization.

${ }^{140}$ Other think tanks mentioned by Petras (p. 121) are: the New Citizenship Project, the Center for Security Policy, the National Institute for Public Policy, the Jewish Institute for National Security Affairs, the Washington Institute for Near Eastern Policy and the Institute for Advanced Strategic and Political Studies.

${ }^{141}$ Christison, B. and K. (2003). In Cockburn, A. and J. St. Clair, (Eds.) The Politics of Anti-Semitism. Petrolia and Oakland, CA: CounterPunch and AK Press, p. 127.

${ }^{142}$ Ibid., op. cit., p. 128.
} 
Abrams, and Bush spokesman Ari Fleischer, whereas the Pentagon was under the pressure of Israel supporters Donald Rumsefeld, Paul Wolfowitz, Dov Zakheim and others. While the names may have changed during Bush's second term in office, the influence remained. The same can be said of the new Obama administration, given the fact that Obama's first appointment was Chief of Staff, Rahm Emanuel, a former volunteer in the Israeli Defense Forces and son of a member of the Irgun. This continuing presence of "Israeli loyalists" in the US administration clearly highlights the effectiveness of the scalar fix of networking.

The persistent pressure on members of congress also ensures that any attempts to criticize Israel for its aggressive policies are effectively silenced. Both Congressman Earl Hilliard and Congresswoman Cynthia McKinney fell victim to this practice, after demanding more fair Middle East policies as well as a proper investigation of 9/11. After AIPAC and other Jewish organizations provided large financial support to their (pro-Israel) opponents, both were defeated in ensuing elections. For Cynthia McKinney, who had tried to fight back by gathering support from Arab-American groups, the battle against the American Jews ended with a media attack by the Lobby for receiving funds from "pro-terror Muslims". ${ }^{143}$ Hilliard's reputation was similarly destroyed in a slandering campaign in the corporate media. In general, the dual loyalties seen in the US government seem to be expected from all American Jews. If a Jew speaks out against Israel, or even reveals the horrendous practices of Israel's continuing dispossession of Palestine in a publication, he or she is openly denounced as a 'self-hating Jew'. 144

Given its immense influence, the Lobby also plays a significant role in the portrayal of Israel in the media and public opinion. At times of war, the Lobby launches huge media

\footnotetext{
${ }^{143}$ Cockburn. (2003). In Cockburn, A. and J. St. Clair, (Eds.) The Politics of Anti-Semitism. Petrolia and Oakland, CA: CounterPunch and AK Press, p. 27.

${ }_{144}$ Jackson, B. (2003). In Cockburn, A. and J. St. Clair, (Eds.) The Politics of Anti-Semitism. Petrolia and Oakland, CA: CounterPunch and AK Press.
} 
campaigns, ensuring that Palestinians (and Arabs from neighboring countries) are portrayed as 'terrorists', while the occupying Israeli army is represented as the victim. ${ }^{145}$ In the 2006 war on Lebanon, the corporate media - pressured by the Jewish lobby - upheld Israel's claim of adherence to the 'purity of arms' doctrine and outright ignored crucial facts of its discriminatory, disproportionate warfare. What was widely omitted was the grossly disproportionate ratio of less than 100 dead fighters to more than 1000 Lebanese civilians who were killed in the Israeli onslaught which launched an average 5,000 missiles and bombs (including cluster and phosphorus bombs) per day. ${ }^{146}$ Like the assault on Gaza in 2008/9, the attack on Lebanon in 2006 had apparently been planned long beforehand, a fact also omitted by the Jewish lobby and mainstream media.

Yet at times of war such as the invasion of Lebanon in 1982 and 2006 or the attack on Gaza in 2008/9, even the powerful pro-Zionist media cannot entirely refrain from reporting on the horrible atrocities committed by Israel. Hence, argues Edward Said, we notice in the aftermath of the war "a tremendous Zionist effort" to bring "the media and the public back into line." 147

\section{Conclusion}

If we recall Swyngedouw's understanding of scale as "embodiment and expression of power relationships" as well as Smith's argument that the scalar fix provides a "platform and container for certain social activities" we find that networking indeed stands out as a function of scalar fix. Using dialectics, we further realize that the scalar fix of networking is internally

\footnotetext{
${ }^{145}$ Petras, op. cit., p. 124.

${ }^{146}$ Ibid., 123.

${ }^{147}$ Said, E. (1994). The Politics of Dispossession: The Struggle for Palestinian Self-Determination, 1969-1994. New York: Vintage Books, p. 100.
} 
related with the scalar fix of legislation. This has been shown in the formation of the Balfour Declaration, as well as the UN Partition Plan, both of which may not have come about without the consolidation of Zionist power through networking.

The scalar fix of networking also pursues a capitalist-imperialist agenda, as the examination of the ZPC reveals. It is the solid establishment of the Jewish influence in the US which has upheld the "special relationship" between the global hegemon and the regional leader of the Middle East, enabling the latter to withstand substantial threats to its existence from neighboring countries for decades. Considering the phenomenon of this "special relationship" from a dialectical perspective shows that there is really nothing "special" about it: the close collaboration between the US and Israel is an internal relation of both the Zionist movement (and, by extension, the State of Israel) and the United States, aiding both significantly in their pursuit of consolidating power.

The examples presented here are by no means exhaustive, but indicate the potential of the networking power. Additional research will have to be done to further our understanding of the scalar fix of networking. The challenge, however, lies in revealing those processes and operations of networking which are often conducted in secrecy in order to avoid the revelation of their manipulative character. 


\section{CHAPTER 6:}

\section{CONSOLIDATING SPATIAL REPRESENTATION - SCALING KNOWLEDGE}

The events [of Oslo II] are a remarkable testimony to the rule of force in international affairs and the power of doctrinal management in a sociocultural setting in which successful marketing is the highest value and the intellectual culture is obedient and unquestioning. The victory is not only apparent in the terms of Oslo I and II and the facts on the ground, but also in the demolition of unacceptable history, the easy acceptance of the most transparent falsehoods, and the state of international opinion, now so submissive on this issue that commentators and analysts have literally forgotten the positions they and their governments advocated only a few years ago, and can even see that 'Israel agrees to quit West Bank' when they know perfectly well that nothing of the sort is true. Noam Chomsky ${ }^{148}$

\section{Introduction}

The scalar fix of knowledge primarily targets one act of dispossession: the denial of a Palestinian narrative and thus the creation of an image of Palestinian 'non-existence'. As the control over the production of knowledge takes on multiple facets, occurring on various levels and affecting a range of elements of society, this chapter examines a range of fields responsible for the dissemination of knowledge - all of which are utilized as means to scale any knowledge related to the Israeli-Palestine conflict.

The first section investigates the field of education, academics and scholarship regarding the history of Palestine, both analyzing how knowledge is imparted and, more significantly, how it is produced. The analysis first addresses the scaling of the Palestinian national curriculum, followed by a discussion of issues regarding scholarship, most notably the historiography of the events of 1948. The second section examines the role of the media in its function of controlling

\footnotetext{
${ }^{148}$ Chomsky, op. cit., p. 558.
} 
the spread of information and knowledge. Addressed are issues of censorship of the Palestinian press as well as the pro-Israel bias of the mainstream media in the West. Building on this discussion the third section analyzes the use of terminology and how public discourse is steered towards a pro-Zionist image that demonizes the Palestinian people, dispossessing them of any opportunity to function as a genuine, sustainable society. The main focus will be on the power of the label of 'terrorism', used to curtail the legitimacy of any resistance to dispossession and to justify the use of force to suppress that resistance.

As has been the case in the previous two chapters, the social factors, or Relations, abstracted in this chapter - education, media and discourse - are understood as internal relations of the Zionist enterprise and its objective of Palestinian dispossession. Bearing this approach in mind, the following narrative exposes acts of dispossession that go in fact beyond the material world of land and water rights, moving to the core of the issue - the Zionists' aim to oppress any form of Palestinian social structure.

\subsection{Education and Academics}

One dimension of scaling knowledge is found in the school education of children, which provides the setting for manipulating the socio-spatial awareness of the youngest elements of society at early age. In an effort to manage the people of the West Bank and Gaza, Israel's military administration implemented drastic, restrictive measures in the realm of producing and disseminating knowledge. This affected the professional and private life of school teachers who were under tight surveillance as engagement in any sort of political activity was strictly prohibited. While those teachers previously employed under Jordanian and Egyptian 
administration were allowed to remain in schools - a measure to enhance the occupation's 'invisibility' - all new hires were subject to approval by the GSS. ${ }^{149}$

Overall, the adherence to the prescribed curriculum was closely monitored to ensure teachers not engage in any extracurricular teaching activities with the potential to plant any seeds of resistance in the children. ${ }^{150}$ The curriculum was constrained to the use of textbooks that had been subject to perusal, whereby chapters with any sort of anti-Israeli content were eliminated. Moreover, any teaching of Palestinian history was censored, as it was feared that such knowledge might foster sentiments of a Palestinian identity and thus stimulate hostility towards the occupation.

The scaling of knowledge was by no means restricted to the Palestinians, for it also targeted the population of Israel, which was made believe that the West Bank is indeed a part of the Jewish state, dropping the fact that there was a place called Palestine into the Orwellian memory hole. The internationally acknowledged border from 1948, the Green Line, was erased from all maps, atlases and Israeli textbooks, while the area itself was no longer referred to as West Bank or eastern Palestine - which would have been the actually correct term - but was given back its biblical names: Judea and Samaria. The Israeli media portrayed the claim that Israel's action in the West Bank and Gaza was not only moral, but also beneficial to the Palestinians. $^{151}$

Contrary to the expectations in the Oslo agreements, the strict censorship of the educational system was not entirely abolished with the official end of the military administration. Even after formally taking control of their educational system in 1994, the Palestinians were

\footnotetext{
${ }^{149}$ Gordon, op. cit.

${ }^{150}$ Ibid., pp. 55-62.

${ }^{151}$ Ibid., pp. 7-9.
} 
"still not masters of their own destiny," and the publication of new school texts was subject to harsh criticism. ${ }^{152}$

In 2000 the Ministry of Education of the Palestinian Authority (PA) introduced new textbooks. This was done after careful analysis of the existing curriculum and textbooks, and a thorough discussion of how to perceive and teach Palestinian history and geography involving teachers from Gaza and the West Bank. Unlike Israeli textbooks, which still contain maps demarcating Israel's border to be the Jordan River, the PA books did not contain any maps of Israel or Palestine, stating that the borders of the former have yet to be defined and those of the latter are still subject to negotiation. They did, however, present a Palestinian narrative describing the declaration of Israel's independence in 1948 as part of the Palestinian Nakbah (catastrophe), during which the majority of native Palestinians were evicted and their villages destroyed. $^{153}$

The textbooks and curriculum were closely monitored by Israeli and pro-Israeli groups in the US, and were strongly condemned in a rather influential report issued by the Center for Monitoring the Impact of Peace (CIMP), which concluded that

[ever] since the PA became responsible for education in 1994, Palestinian children have been learning from their schoolbooks to identify Israel as the evil colonialist enemy who stole their land. $^{154}$

After being quoted and referred to by a number of US politicians, including then President Clinton who called on the PA to change the "culture of violence and ... incitement that, since Oslo, has gone unchecked," 155 the CIMP report had a drastic impact on the development policies of donor countries as well as international organizations. The World Bank

\footnotetext{
${ }^{152}$ Moughrabi, F. (2001). The Politics of Palestinian Textbooks. Journal of Palestine Studies, 31 (1), p. 6.

${ }^{153}$ Ibid., p. 7.

${ }^{154}$ Qtd. in Moughrabi, op. cit., p. 8.

155 Ibid.
} 
decided to divert money designated for educational needs to other sectors, whereas Italy withdrew its funding for developing a new Palestinian curriculum all together. A study found that, by merely relying on the CIMP report without examining the books themselves, numerous governments and donor groups failed to realize that the document contained many falsehoods, most notably its claims that the PA school texts delegitimized Israel and advocated anti-semitic books. In reality, the new Palestinian texts, contrary to CIMP's accusations, did not contain any negative stereotypes of Jews, whereas Israeli school books "continue to present Israelis as peace loving and Arabs as terrorists who prefer war." 156

The practice of scaling knowledge and discourse also prevails in academics and public discourse, both in Israel and Palestine but also abroad. Under the military administration in the West Bank and Gaza, a large number of academics and intelligentsia, especially those trained abroad, were driven out from the West Bank and were often times not allowed to return, an act facilitated by the fact that many of them were considered 'foreigners' since they happened to be abroad at the time of the census in 1967. In addition, student life was made rather difficult, as dormitories were frequently disturbed by night raids and going to class was disrupted by military checkpoints and the confiscation of student IDs. ${ }^{157}$

In addition to the control of what type of knowledge is imparted, the scalar fix manifests itself in the influence on the production of knowledge, in our case the historiography of the Palestine-Israeli conflict. While much of what has been written (excluding publications from Arab sources) shows an overall bias towards Israel, scholarship has particularly denied the facts of the circumstances that led to the declaration of Israel's statehood - the ethnic cleansing of 1948. As the Israeli historian Ilan Pappe observed:

\footnotetext{
156 Ibid., p. 16.

${ }^{157}$ Chomsky, op. cit., p. 134.
} 
...when it comes to the dispossession by Israel of the Palestinians in 1948, there is a deep chasm between the reality and the representation. ... There is no doubt that the ethnic cleansing of 1948, the most formative event in the modern history of the land of Palestine, has been almost entirely eradicated from the collective global memory and erased from the world's conscience. ${ }^{158}$

For several decades after the war, the Zionist historiography presented a rather distorted account of the events on the ground in relation to the Jewish "war of independence." The official Israeli version stated that the Palestinians had left their homes voluntarily, as "Arab leaders broadcast orders ... to evacuate their country preliminary to its 'invasion' by the regular Arab armies." ${ }^{159}$ While several Arab scholars, including Walid Khalidi, tried throughout the 1960s and 70s to investigate the true circumstances of the civil war, mainstream Israeli scholars abided by the version of the Israeli government. It was not until the 1980s, when the declassification of Israeli archives enabled 'New Historians' like Tom Segev, Avi Shlaim and Benny Morris to depart from the official narrative and address the occupation, destruction and expulsion of large parts of Palestine. Yet, Khalidi points out "a lingering reluctance even in these writings" to see the relation of the expulsion of the Palestinians to the Zionist objective of Judaizing the land. ${ }^{160}$ On the contrary, the incidents of the Nakbah and the civil war are portrayed in isolation, as if their concurrence in time was merely accidental. In what was to become the first groundbreaking work disclosing the realities of the ethnic cleansing of the Palestinians, Benny Morris still adhered to the Zionist version of history, to the extent that he failed to conclude that the expulsion of the Palestinians was a willful act. Instead he stated that they partially "left" as a result of the war. ${ }^{161}$

\footnotetext{
${ }^{158}$ Pappe, (2006), 1948 Ethnic Cleansing, op. cit., p. 8.

${ }^{159}$ Khalidi, Palestinian Identity, p. 4.

${ }^{160}$ Ibid., p. 5.

${ }^{161}$ Said, End of the Peace Process, op. cit., p. 274.
} 
A somewhat alternative, yet similarly misleading view has advocated a causal fallacy, claiming that it was the civil war itself which "inevitably" led to the expulsion of the Palestinians, rather than the other way round. Pappe accounts as one reason for the Nakbah denial for several decades the "absence so far of the paradigm of ethnic cleansing." ${ }^{162}$ He further argues that the civil war of 1948 was "the consequence, the means" to carry out the planned eviction of Palestinians. ${ }^{163}$

This reluctance to see the Nakbah in the proper - relational - perspective does not seem to have changed much. Even as late as 1998, at a conference between Palestinian and Israeli scholars, the latter represented by the 'New Historians' Morris, Pappe and Sternhell, the Israelis considered the Zionist political movement and the violent expulsion of a quarter million Palestinians in 1947/48 a "necessity'. ${ }^{164}$ Furthermore, in his "objective" account on the ArabIsraeli conflict from 2001, Righteous Victims, Benny Morris still does not take the thoroughly planned ethnic cleansing for what it was. While the book presents more than a century of history in painstaking detail, the blueprint for the ethnic cleansing, Plan Dalet is mentioned only briefly, without any detailed attention to the meticulous planning which provided the basis for the expulsion of the Palestinians. Addressing the refugee problem, Morris even argues that, in light of the disastrous socio-economic conditions in Palestine, "for some, exile may have become an attractive option, at least until Palestine calmed down." While he acknowledges that the Zionist leadership did espouse a compulsory transfer of Palestinians to the neighboring Arab states and that "Plan D[alet] clearly resulted in mass flight," he states that there was never an official,

\footnotetext{
${ }^{162}$ Pappe, (2006), 1948 Ethnic Cleansing, op. cit., p. 17; see also: Pappe, (2007), Ethic Cleansing of Palestine, op. cit.

${ }^{163}$ Ibid., p. 18, emphasis in original.

${ }^{164}$ Said, End of the Peace Process, op. cit., p. 274.
} 
"systematic expulsion policy." Rather, he concludes, the "exodus was, overall, the result of a cumulative process and a set of causes."165

The issue is handled with similar care by Avi Shlaim. In his book, Iron Wall, he first argues that Plan Dalet was "not a political blueprint for the expulsion" of the Palestinians and that it merely served "military and territorial objectives." Then follows a somewhat contradicting statement, in which Shlaim acknowledges that the violent eviction of the Palestinians was "permitted and justified", as Plan Dalet ordered "the capture of Arab cities and the destruction of villages."166

Apart from questions of the right paradigm to produce knowledge and how to incorporate newly available sources of declassified documents, we also need to consider the authenticity of the very files which serve as evidence for any historiography regarding the events of 1948. In 1995, Morris claimed that the Zionists had buttressed their distorted version of history by forging several files from the period of the civil war in 1948. Among a number of documents Morris examined the diaries of two Zionist leaders: Yosef Weitz ${ }^{167}$ and David Ben-Gurion. While the version of Weitz' diary published in 1965 differed significantly from his original notes, leaving out references to the 'transfer' of the Palestinian population ${ }^{168}$, an examination of Ben-Gurion's diary - after being cross-referenced with other contemporaneous documents - showed that, "essentially, Ben-Gurion had exercised effective self-censorship decades before the official censors arrived on the scene."169 This shows the depths in which knowledge and information can

\footnotetext{
${ }^{165}$ Morris, Righteous Victims, op. cit., p. 257. The "set of causes" refers to both Jewish and Arab resistance to British rule, the latter's resistance to the Zionist enterprise and the Jewish refugee problem, making the Zionist objective of Judaization just one among many other reasons.

${ }^{166}$ Shlaim, A. (2000). The Iron Wall: Israel and the Arab World. Allen Lane Penguin Press: London, p. 31.

${ }^{167}$ Yosef Weitz was Director of the Lands Department of the Jewish National Fund (JNF) and sat, among others, on the Transfer Committees of 1937-38 and 1948-49. See Morris, B. (1995). Falsifying the Record: A Fresh Look at Zionist Documentation of 1948. Journal of Palestine Studies, 34 (3), p. 45.

${ }^{168}$ Ibid., p. 46.

${ }^{169}$ Ibid., p. 51.
} 
be manipulated to create a 'reality' which falsifies what was actually said and what really happened. Thus, while the examination of original documents is essential for the writing of history, this has to be done with extreme care.

It should be further noted that, overall, knowledge on Palestinian history has been written mainly by non-Palestinians, oftentimes unable to avoid a certain bias. Even if an honest attempt to objectivity is made, there are restrictions due to the biased use of sources, which often focus on Western or Zionist documents, without hearing the Palestinian voices, those who in fact experienced that history. Palestinian society thus becomes an "object rather than a subject of history" which "can be described by others, but cannot describe itself." 170 This has facilitated efforts to deny both the formation of a Palestinian identity and the narration of the people's own history.

To the extent that Palestinian scholars did conduct research on their people's development, Israeli dominance over Palestine and the wider area has had a severely damaging impact on such scholarship. Most notably, as a consequence of Israel's 1982 invasion of Lebanon, a significant amount of documents and research that had been produced by the Palestine Research Center and the Institute for Palestine Studies in Beirut was either seized by Israeli forces or brought into safety, in both cases remaining inaccessible for a long time. This is but one example of the relentless disruption of Palestinian scholarship which contributes to the dispossession of the Palestinian narrative.

The invasion of Lebanon in 1982 also marks a shifting point in the way Palestinian 'nonexistence' is generally handled in Israeli and pro-Israeli discourse and scholarship. Whereas in earlier years the formation of a Palestinian national identity was just ignored all together, the aftermath of the 1982 war witnessed a more aggressive discourse of culture and history which

\footnotetext{
${ }^{170}$ Khalidi, Palestinian Identity, op. cit., p. 92.
} 
openly dealt with the contemporary Palestinian people. Edward Said pointed towards two books published in 1984 which drew much public attention and, after receiving numerous praising reviews from major influential newspapers and journals, ranked high on the bestselling lists in the United States. The first one is Joan Peters' study on the history of the Palestinian people, From Time Immemorial, in which she claims that the majority of the population of Palestine in 1948 was recent immigrants from neighboring Arab countries, and thus could not be considered part of an indigenous non-Jewish population in Palestine. The book thus perfectly conforms with the Zionist thesis and public opinion that there is no such thing as an indigenous Palestinian people which could have any claim to the land, but that it is really the Jewish people that is entitled to a sovereign state in Palestine. What is even more noteworthy, whereas similar theses may have been discussed in scholarly circles, this book was addressed to a much wider audience in the US, thus supporting the 'education' of the general public according to pro-Zionist and antiPalestinian lines. ${ }^{171}$

A similar judgment can be made about the second book addressed by Said, Leon Uris' The Haj. Being a bestselling novel, it reached an even wider audience than Peters' book. The story is set in what is presented as everyday life in Palestine, whereby the Arab is portrayed as a "lecherous, deceitful, murderous, irrational, larcenous, and utterly reprehensible subhuman, while the Jew is "noble, intelligent, understanding, courageous, and, above all, deserving of Palestine." Albeit being full of "sheer disgusting hatred" and loathing, the book was publicly lauded as a "work of penetrating, compassionate, and courageous humanism."

\footnotetext{
${ }^{171}$ Peters" "selective and tendentious use of sources, systematic misquotation, and other unscholarly methods" are criticized in Edward Said, End of the Peace Process, op. cit. and Khalidi, Palestinian Identity, op. cit. Khalidi (p. 93) suggests the book, and the praise it received by prominent figures, had a significant impact "in reinforcing crucial stereotypes regarding Palestine in American public discourse."

${ }^{172}$ Said, Politics of Dispossession, op. cit., p. 104; see also Chomsky, op. cit.
} 
Over the years, even those on the left who were once critical of Israel and have stood up for those being dispossessed by imperialist ventures have moved more towards rightist lines supporting the Zionist-imperialist logic. Both Chomsky and Said have condemned The New Republic, a journal for politics and arts respected by liberals and "right-thinking intellectuals,"173 for its adoption of a strongly pro-Zionist attitude. In an article about a play describing the relations between a German businessman, an immigrant Jewess, and an Arab Palestinian in Jerusalem, the journal's editor Martin Peretz, in denial of his true identity, simply described the Palestinian in the play as an "Arab",

a crazed Arab, to be sure, but crazed in the distinctive ways of his culture. He is intoxicated by language, cannot discern between fantasy ad reality, abhors compromise, always blames others for his predicament, and in the end lances the painful boil of frustration in a pointless, though momentarily gratifying, act of bloodlust.

Peretz continues affirming the play's "truthfulness", for "we have seen this play's Arab in Tripoli and in Damascus, and ... in hijacking a bus to Gaza and shooting up a street of innocents in Jerusalem."174

On the other hand, scholars and intellectuals in the US and Europe wanting to criticize Israel's politics of dispossession in Palestine often face harsh consequences. A point in case is the career of the "accomplished scholar" and "excellent teacher" Norman Finkelstein, who became known as an outspoken critic of Israeli politics towards the Palestinians, in particular its abuse of the Holocaust. ${ }^{175}$ Already during his graduate studies did Finkelstein dare to denounce Joan Peters' above-mentioned, fraudulent work, From Time Immemorial. ${ }^{176}$ His 2005 book,

\footnotetext{
${ }^{173}$ Ibid. p. 104.

174 Ibid.

175 Jensen, R. (2007, May 25). What the Finkelstein Tenure Fight Tells Us About the State of Academia. CounterPunch.

${ }^{176}$ See Finkelstein in Said, E. and C. Hitchens, Eds. (1988). Blaming the Victims: Spurious Scholarship and the Palestine Question. London: Verso.
} 
Beyond Chutzpah: On the Misuse of Anti-Semitism and the Abuse of History, which reveals the practice of distorting facts in order to rewrite history under the disguise of academic scholarship, caused a public controversy with far-reaching consequences. The work used Harvard law professor Alan Dershowitz' Case for Israel as a "springboard" to show the misrepresentation of the documentary record of human rights issues involving Israel, a fact which Dershowitz was unwilling to let pass without a response. ${ }^{177}$ While Finkelstein's book was still in writing, Dershowitz initiated a letter campaign trying to prevent the work from being published. Apart from pressuring the publisher, University of California Press, Dershowitz took the apparently unprecedented step of appealing to California governor Schwarzenegger. ${ }^{178}$ While these measures did not succeed, Dershowitz continued his campaign against Finkelstein, contributing to the fact that the latter's book was widely ignored and, within 5 months of being published, did not receive "a single review from mainstream U.S. publication", whereas The Case for Israel has been frequently cited as a reference. Moreover, the argument between the two scholars damaged Finkelstein's academic career, for he was denied tenure at DePaul University, where he had been an assistant professor of political science. This is but one case that illustrates "what seems to be the growing gap between the facts on the Middle East as accepted by scholars and the representation of the Middle East situation to the wider public."

\subsection{Media}

The control of knowledge, i.e. the dispossession of the Palestinian's right to freedom of speech, has generally involved the regulation and distribution of any type of information in the Palestinian territories. Under the military regime, the publication and distribution of newspapers

\footnotetext{
${ }^{177}$ See Special Document File in Journal of Palestine Studies, 35 (2), (Winter 2006), pp. 85 - 99.

${ }^{178}$ Wiener, The Nation, qtd. in Journal of Palestine Studies, (Winter 2006), p. 89.

${ }^{179}$ Ibid, p. 86.
} 
was subject to a permit, whereby the term 'newspaper' included "any pamphlet containing news, information, events, occurrences, or explanations relating to news items, stories or any other item of public interest," in other words, anything potentially affecting society one way or another. ${ }^{180}$ Thus virtually all reporting could only be done under strict censorship, so that articles addressing the situation under occupation - be it curfews, strikes, or the dispossession of land and water could usually be mentioned only briefly, without providing any details or background information. Anything deemed to have "illicit political content" was strictly prohibited. This included "pictorial representations of Israeli soldiers assaulting Palestinian civilians, schools surrounded by barbed wire, and the use of the colors of the Palestinian flag together."181

Moreover, all published material was censored as to not encourage any discussion of Palestinian identity. The inhabitants of the West Bank and Gaza were thus not referred to as 'Palestinians' - which would imply a feeling of national identity - but as 'Arabs', hoping that they would thus develop some form of pan-Arab sense of belonging. This also shows the clear distinction Israel made between the Palestinian land and resources on the one hand and the indigenous people on the other. While it was very much interested in absorbing the former, it strove to expulse the latter by alienating the Palestinians from their land and destroying their history and identity.

Censorship of the Palestinian press intensified during and after Israeli attacks on neighboring territory. Once again, the invasion of Lebanon in 1982 serves as a case in point. ${ }^{182}$ Claims by the Civil Administration to allow and encourage freedom of expression notwithstanding, the reality on the ground told a quite different story. A respective study listed an array of incidents during the year following the invasion of Lebanon where Palestinian

\footnotetext{
${ }^{180}$ MO 50, qtd. in Gordon, op. cit., p. 37.

${ }^{181}$ Ibid.

${ }^{182}$ See Friedman, R. (1983). Israeli Censorship of the Palestinian Press. Journal of Palestine Studies, 13 (1), 93-101.
} 
journalists and editors were prevented from doing their work, including measures such as detention, beating, torture and threat of deportation. Primary targets were the three Arab dailies in East Jerusalem: Al-Fajr, Al-Sha'ab, and Al-Quds - the very same papers Israel has used as signboard for Palestinian freedom of press. The extent of press censorship was most obvious in the reporting on local news: topics such as the creation of new Jewish settlements, the dispossession of Arab land, but also the arrest of PLO members and the destruction of their family homes were strictly prohibited. Moreover, news regarding the detention and deportation of Palestinian intellectuals and academics or the closing of schools was frequently censored. ${ }^{183}$ Yet, similar to the military's permit regime, the strict censorship did not succeed in suppressing the rising resistance against Israeli occupation of the OT.

The dispossession of the Palestinian narrative and of the Palestinians' right to be a distinct, self-conscious people is also apparent in the Western media and its pro-Israeli bias. News reporting in the US as well as in Europe is generally one-sided and distorted. The British Broadcasting Corporation, BBC, serves as an illustrative example. Contrary to claims to impartiality, honesty and integrity, the BBC's reporting has been rather supportive of Israel, displaying a clear antipathy towards Palestine. This was confirmed by two independent studies conducted between 2004 and 2006, one of them commissioned by the BBC itself. ${ }^{184}$ Both studies found that reporting on the Palestine-Israeli conflict lacks depth and detail, leaving the average audience no opportunity to fully comprehend the complexity of the conflict. Not only are aspects of the conflict, which would bring understanding of the Palestinian 'side' of the story, regularly omitted, there is hardly any mentioning of the suffering of the Palestinians which has been a

\footnotetext{
${ }^{183}$ Ibid., p. 100.

${ }^{184}$ One study was conducted by the Glasgow University Media Group Study of Middle East News Coverage, the other by an independent panel, the Communications Research Centre at Loughborough University, in collaboration with British - Israeli international lawyer Noam Lubell.
} 
daily reality for six decades. In contrast, victimhood is ascribed to the Israelis, particularly the settlers. Whereas their housing complexes have disrupted or destroyed thousands of Palestinian livelihoods, the settlers' 'hardship' in light of Palestinian resistance is perpetually overemphasized. Gaza and the West Bank are generally merely referred to as 'disputed' territories, thus denying the fact that the occupation of Palestine is an illegal act condemned by the international community. The Golan Heights, however, are not presented as occupied territory at all. Similarly, the issue of growing settlements and continuous confiscation of Palestinian land is hardly mentioned, and never condemned as 'illegal', thus ignoring international law and UN resolutions, such as Resolution 194. Thus, whereas Israeli rights especially those of existence and self-defense - are repeatedly emphasized and supported, Palestinian rights are outright ignored. ${ }^{185}$

Instructive is also the representation of the signing of the Oslo II agreements in 1995 in the US media. The event was celebrated as "a historic compromise", "a big one, making the historic move toward accommodation of the two peoples all but irreversible." Reports that Israel had "agreed to quit the West Bank" and to extend "Palestinian rule to most of the West Bank" stood, once again, in stark contrast to the reality, which had Israel in control of no less than two thirds of the West Bank, at the time home to some 140,000 Jewish settlers, whereas the PA was granted full control over merely $3 \%$ of the total land. ${ }^{186}$

Overall, the brutal warfare of Israel was and is not discussed widely in mainstream media and public discourse. As the corporate, Western media generally supports the Zionist narrative safeguarded through an invisible line, "like a charged electrical cable" ${ }^{187}$ - criticism of Israel and

\footnotetext{
${ }^{185}$ Lendman, S. (2008, June 13). BBC's Pro-Israeli Bias. Centre for Research on Globalization.

${ }^{186}$ Chomsky, op. cit., pp. 540 and 554.

${ }^{187}$ Alam. (2003). In Cockburn, A. and J. St. Clair, (Eds.) The Politics of Anti-Semitism. Petrolia and Oakland, CA: CounterPunch and AK Press, p. 73.
} 
American politics in the Middle East is closely monitored and restricted by the Jewish lobby. Attempts to cross the line are often times responded to with harsh slandering campaigns and accusations of anti-Semitism by the Lobby. Journalist Alexander Cockburn, for instance, was described as "a nasty piece of work", "despicable" and with a "double moral standard" after giving a detailed, truthful account on the invasion of Lebanon in $1982 .{ }^{188}$ Similarly, Independent Middle East correspondent, Robert Fisk, having reported on the wars and conflicts of the Middle East for more than three decades, states that the hate mail against him has become increasingly violent and vulgar over the years, even including death threats. Another example is Northeastern University of Boston professor, M. Shahid Alam, whose call for an academic boycott - intended to be part of a peaceful alternative to violent resistance in Palestine - was greeted with stark hostility in the corporate media which portrayed him as defender of Palestinian suicide bombers. ${ }^{189}$ Israeli journalists are likewise affected, as the case of Amira Hass shows. After living under Israeli occupation in Gaza and currently residing in Ramallah, to experience for herself the situation for the Palestinians, the Haaretz correspondent receives offensive and abusive messages "in the thousands."

But not only courageous journalists are silenced. An official report by the MacBride Commission established to investigate Israel's alleged war crimes during the 1982 invasion of Lebanon found Israel guilty of violating international law, using prohibited weapons and indiscriminately bombing civilian targets. The report was widely ignored in the West, especially in the US, where the commission's findings were not even published. ${ }^{191}$

\footnotetext{
${ }^{188}$ Chomsky, op. cit., p. 273.

${ }^{189}$ Fisk and Alam (2003). In Cockburn, A. and J. St. Clair, (Eds.) The Politics of Anti-Semitism. Petrolia and Oakland, CA: CounterPunch and AK Press, pp. 59 and 75.

${ }^{190}$ Fisk, op. cit., p. 561.

${ }^{191}$ Said, Politics of Dispossession, op. cit., pp. $247 \mathrm{ff}$.
} 


\subsection{Terminology and Public Discourse}

The differential terminology in public discourse reinforces the consolidation of identity, i.e. the notion of an ideology of difference. As if to confirm Samuel Huntington's thesis, we are led to believe that there is indeed a 'clash' of two civilizations which are not only incompatible, but whose relationship is defined by the moral superiority of one over the other. Whereas Israelis are 'murdered' or 'lynched' by Palestinian 'terrorists', Palestinians are 'merely' killed or shot in 'stone-throwing clashes' and confrontations that could not be avoided by those Israeli soldiers trying to 'defend' themselves and ensure the 'security' of the Israeli citizens. ${ }^{192}$ Furthermore, while Israel is portrayed not only as innocent victim, but also benefactor to the Palestinians and Arabs in general, the PLO and later on Hamas, representing the Palestinians, has been portrayed as a "gang of thugs", "the centre of a cancerous growth which has metastasized all over the world." 193

To this day, public discourse provides no consideration for the overall context, as Palestinians are dispossessed of their memory and past, and thus the world is denied a crucial part of the overall story, debilitated of making a sound judgment. The issue of ethnic cleansing as if it never happened - is still not addressed in public discourse, let alone negotiations for peace. All the while, it has been central to the Palestinian narrative and the way Palestinians have defined themselves and their resistance towards the aggressor ever since. On the contrary, Israel's created 'facts on the ground' have come to be accepted as Palestinian historiography, as the ultimate truth.

Edward Said finds it "simply extraordinary and without precedent" that Israel's history of a state founded on conquest and terrorism and its continuing occupation of what little is left of

\footnotetext{
${ }^{192}$ Fisk, op. cit., p. 551.

${ }^{193}$ See Fisk and Chomsky, op. cit.
} 
the Palestinian territory, in violation of international law, is never brought up in any public discourse, nor subjected to careful analysis in the Western media or scholarship, or by US politicians. $^{194}$

Israel's repeated attacks on its surrounding territory - be it the wars on Lebanon in 1982, 1993 and 2006, the conquests of the Golan Heights in 1967, or the various assaults on the West Bank and Gaza - reveal the perpetual distortion of reality and the (mis-)representation of sociospatial practices in order to serve Israeli interests. This begins with the very names given to military operations. In 1982, Israel launched a mission dubbed "Peace for Galilee", a term which not only represented the official rhetoric from the Israeli government, but implied that Israel aimed to ensure 'peace' and 'security' and. The true nature of the operation, i.e. the military action to invade Beirut and to impose US-Israeli dominance on Arab neighbors was concealed, and the invasion was justified as necessary in order to protect the border areas and destroy the "nests of terrorists.", 195

Furthermore, the brutal warfare and mass slaughtering that occurred during the invasion illegal by international standards - received little critical attention or denouncement and had no consequences - be it legal or diplomatic - for the Israelis. What was stressed in public discourse instead was Israel's claim to have warned the Lebanese population, ignoring the fact that such warnings were, of course, to no avail, for the civilians simply did not have the time to escape. Throughout the assaults on Gaza in 2006 and 2008 not only time was an issue, but also space, as the people under attack - already imprisoned by Israel's closing of the border crossings - had virtually nowhere to escape.

\footnotetext{
${ }^{194}$ Said, End of the Peace Process, op. cit., p. 46.

${ }^{195}$ Chomsky, op. cit., p. 219.
} 
Another theme utilized to bend the truth of Israel's warfare is what Chomsky calls the "cease-fire-exploitation-doctrine." Rather than prescribing an actual end to the war, the Israeli policy of announcing a ceasefire constitutes merely a cessation of the shooting, as doing so works to the aggressor's advantage. ${ }^{196}$ In the war on Lebanon in 1982, ground forces stopped the gunfire but stayed in place to ensure "stability" in the "security zone" (read: occupy southern Lebanon), whereas Gaza remains under occupation, with its borders tightly closed, just as it was before the attack in December 2008. As of this writing, a truce between Israel and the Palestinian factions (i.e. the corrupted Fatah and the ruling Hamas) has not been accomplished. Finally, the unilateral ceasefire is always made at a time most advantageous to the aggressor. It either benefited Israel to use the time of 'rest' for reinforcement, or it helped sustain the image of the ‘desire’ for peace.

In addition to Israel's image of wanting 'peace and security' for its own people, especially in the settlements of the border areas, it is also portrayed as the 'liberator' and 'benefactor'. In the case of the war on Lebanon in 1982, the Christians were portrayed as being in need of rescue from the terrorist activities of the PLO and the Syrians. In the wars on Gaza since the beginning of the rule of Hamas, Israel's military action has been justified as bringing good to the Palestinians in Gaza, who are conceived to be harmed by Hamas' terrorist rule rather than Israel's decade-long oppression.

The benign character of Israel's military operations is further enhanced through its alleged adherence to the "Jewish doctrine" of tohar haneshek, i.e. "purity of arms", according to which Israeli forces only strike strategic targets, buildings and places from which the enemy - be it terrorist PLO or Hamas - was deemed to be operating. The realities on the ground, however, generally show a very different picture of majority civilian casualties and numerous towns and ${ }^{196}$ Ibid. 
villages destroyed. An account of the Israeli invasion of Lebanon in 1982 by Mordechai Bar-On, a Peace Now activist who viewed the PLO as "malicious, vicious and cruel" confirms:

Anyone who visited Southern Lebanon during and even after the fighting would see that the war was fought not just against terrorist organizations and the PLO, and not even solely to destroy the PLO's military infrastructure in the region. It was fought against the very existence of the Palestinians as a community with its own way of life, ... [against the] health and educational services, political and social organizations, judicial and self-management systems, etc. Now that all these autonomous social systems have been utterly destroyed, the Palestinian refugees have once again become a faceless mass of people, uprooted, evacuated and torn away from any form of collective life. ${ }^{197}$

Also consider the power of terminology after the outbreak of the second intifada, when US embassies in the region were instructed by US Secretary of Defense, Colin Powell to no longer refer to the Palestinian territories as 'occupied' but as 'disputed'. ${ }^{198}$ This change in terminology delegitimized Palestinian resistance, for a struggle against an illegal occupation considered an act of war under international law - may be justified, whereas downgrading the intifada to a 'dispute' suggests something that might be settled through talks and negotiations. The unequal representation of the two sides continued during this 'dispute'. Thus, whereas an attack on an illegal settlement in the West Bank killing four Israeli settlers was referred to as a 'massacre', the preceding onslaught of the town of Jenin - killing some thirty armed Palestinians but also 24 civilians - did not qualify as such. ${ }^{199}$

The verbal abuse for Palestinians in public discourse has been another significant component of the representation of the conflict. They have been bestialized, robbed of their identity, deprived of their collective history and memory as they were turned into "cockroaches in a glass jar", "serpents" and "crocodiles". Over the decades, Palestinians have been portrayed

\footnotetext{
${ }^{197}$ Qtd. in Chomsky, op. cit., pp. 255/6.

${ }^{198}$ Fisk, op. cit., p. 591.

${ }^{199}$ Ibid., op. cit., p. 615.
} 
as nothing but a "cancerous manifestation" against which "chemotherapy" (i.e. military actions by Israeli 'Defense' Forces) is the only "cure" ${ }^{200}$ How easy is it then to designate these people "outside the boundaries of reason" as terrorists who simply couldn't be talked to and negotiated with $?^{201}$

The label of terrorism may be the most powerful tool used to curtail the legitimacy of resistance against imperialist expansion, invoked when deemed beneficial as part of a greater political and economic strategy. There seems to be indeed a particular 'logic of terror' operating within Harvey's territorial logic of coercive power. Like any other branding of similar notion it is generally applied in isolation from any situational and historical circumstances, taken out of context, ignoring the representation of the socio-spatial environment which gave rise to the social action deemed 'terrorist' in the first place. ${ }^{202}$ The terrorism label, hence, does not ask for the causes of events, for the underlying symptoms, nor does it go into any structural, analytical depth.

It should be noted that the current phase of the terror logic - the War on Terror launched by the Bush administration - is by no means a new invention, for this war shows amazing parallels to the war on terrorism launched by President Reagan in the 1980s. Even the policy makers acting 'behind the scenes' are in many cases the same as under the Reagan administration. Bush's Secretary of Defense, Donald Rumsfeld, acted as Reagan's special representative to the Middle East, whereas the American ambassador to the UN, John Negroponte, represented diplomatic relations in Honduras.

Given that terrorist practices and accusations thereof have been part of politics and warfare for quite some time, it seems a curiosity that neither politicians and diplomats (including

\footnotetext{
${ }^{200}$ Ibid., p. 624.

${ }^{201}$ Ibid., p. 464.

${ }^{202}$ Said, Politics of Dispossession, op. cit., p. 342.
} 
the United Nations) nor intellectuals and scholars have succeeded in providing a general definition of what constitutes terrorism, a fact which in itself speaks for the power of the term. As the "academic specialist" on terrorism, Walter Laqueur, explained, "no definition of terrorism can possibly cover all the varieties of terrorism that have appeared throughout history: peasant wars and labor disputes and brigandage have been accompanied by systematic terror, and the same is true with regard to general wars, wars of national liberation and resistance movements against foreign occupiers."203

Nonetheless there have been numerous resolutions addressing the issue of terrorism passed by both the UN Security Council and General Assembly. In 1987, the GA approved almost unanimously a resolution that generally condemned terrorism and sought to prescribe measures for its prevention, yet also reaffirmed

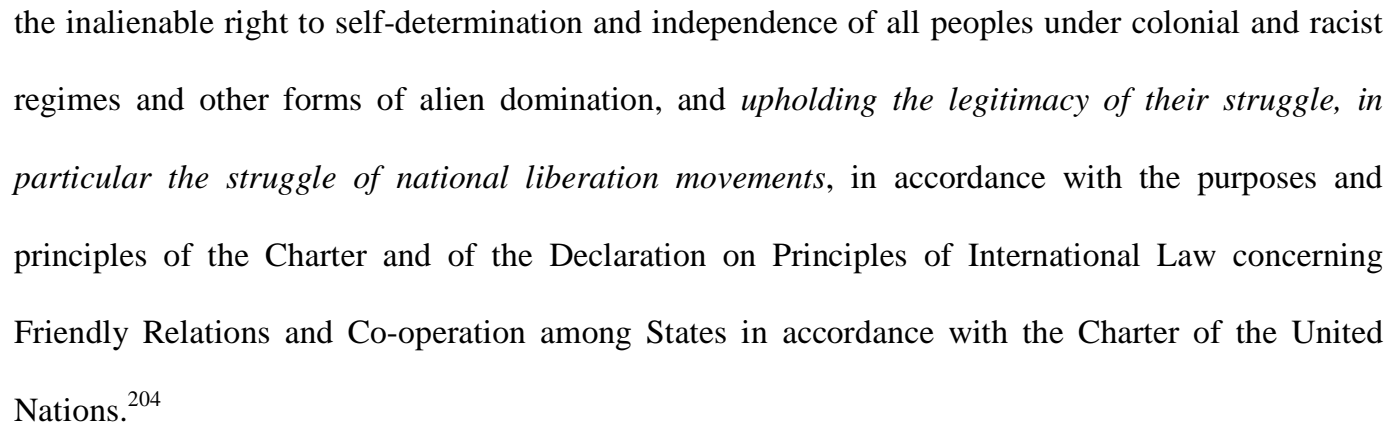

Most notably, only two countries voted against the resolution: the US and Israel, precisely because of this clause, which at the time was directed at the Apartheid regime in South Africa and Israel's occupation of the West Bank and Gaza. The rejection of the resolution is perspicuous if we consider how the concept of terrorism is employed in political and public discourse by the US, Israel and other clients or allies, which is clearly not in congruence with the above mentioned clause.

\footnotetext{
${ }^{203}$ Qtd. in Said, Politics of Dispossession, op. cit., p. 343.

${ }^{204}$ UNGA, A/RES/42/159, my emphasis.
} 
This lack of a proper, unanimously agreed definition, however, makes the label of terrorism more easily applicable, particularly to concepts considered a threat to the structural system and the rule of those making accusations of terrorism, i.e. those in control of representations of space (conceived space). Thus Israel has been free to apply the 'terrorism' label not only to Palestinian refugees in Lebanon and elsewhere, but also to their leadership, especially when the latter poses an increasing threat to the status quo.

The story of Israel's relationship with the PLO is worth considering here. While initially being treated in similar manners as at present Hizbollah and Hamas - i.e. as a 'terrorist' movement that cannot be negotiated with and whose 'terrorist' activities pose such a threat to Israel's security that in 1982 a war against the PLO's host country, Lebanon, was not simply justified but 'unavoidable' - Israel's attitude towards the PLO changed significantly throughout the 1990s, when a new label was put on the diplomacy table: the 'peace process'.

The revival of the peace process came at a time of waning popular support of the PLO as accusations of corruption, opportunism and disrespect for the people's interests grew wider and louder. Facing the internal threat of competition from increasingly popular movements such as Hamas, the PLO became more open towards US-Israeli peace initiatives. In the aftermath of the Oslo Accord, Arafat was presented as having been 'forced' by Israelis to accept the latter's terms for a peace agreement.

After Arafat's concessions and official recognition of Israel - the price he paid to be removed from the terrorist list - the PLO's place as the terrorist enemy was taken by Hamas and Hizbollah. Both have been repeatedly discredited as terrorist movements, which facilitated numerous military campaigns by Israeli 'Defense' Forces. A point in case is Israel's 1993 attack on Lebanon, dubbed "Operation Accountability", where history was rewritten by shoving the 
truth - namely, that Israel had been the aggressor - down the Orwellian memory hole and creating the 'fact' that it was Hizbollah who had "started the latest round of fighting in an effort to sabotage the peace negotiations and provoke a wider conflict." 205 A similar process preceded the most recent war on Gaza, were the official story defied the fact that it was Israel, not Hamas, who had broken the ceasefire, presumably placing Israel once more into the position of the victim. Once the public was made to believe that Hamas is a 'threat' to Israel it was easy to justify and gather international support for an all out war on the people of Gaza.

Edward Said pointed out that the terrorism label is never used by those allegedly performing acts of terror, but by those who consider themselves as under 'attack'. ${ }^{206}$ Serving to classify 'our' enemies, who are against 'our' policies, values and morals, the label is often associated with a threat to our "stable identity", based on our nationality, religion, culture and tradition - the values of which are often not shared or at times contested by marginalized groups who seek to define themselves on other grounds. ${ }^{207}$ In other words, the 'terrorism' label is intrinsically linked with the scalar fix of identifying 'us' against the 'other'. In Said's words, this is facilitated by a

limited access to the media coupled with an almost perfect correspondence between the ideology ruling the presentation and selection of news (whose agenda is set by certified experts hand in hand with media corporate managers) on the one hand, and prevailing government policy on the other, [which] maintains a consistent pattern in the U.S. imperial perspective toward the non-Western world. $^{208}$

What's more, the implication of 'us' being the 'good' who are threatened by 'them' further legitimizes any actions we do in order to extirpate the 'evil'. The label or, to use Said's

\footnotetext{
${ }^{205}$ Elaine Sciolino, qtd. in Chomsky, op. cit., p. 521.

${ }^{206}$ Said, Politics of Dispossession, op. cit., p. 350.

${ }^{207}$ Ibid., p. 353.

${ }^{208}$ Ibid., pp. 353/4.
} 
term, "enveloping cloud" of terrorism provides easy justification for oppressive measures against Palestinians in Israel or the West Bank and for destructive wars in Lebanon or Gaza. ${ }^{209}$ It turns Palestinians into 'two-legged beasts', a 'cancerous growth' that needs to be eradicated by Israel the conceived showcase for peace, freedom and democracy in the Middle East.

The 'other', representing an unknown threat to us, to our very existence, is silenced and does not nearly receive the same representation in the media or public discourse; and if so a largely negative image is portrayed. As the Palestinian narrative has been subject to "memoricide", the struggle of the people becomes increasingly difficult. As Said described this form of dispossession:

With no acceptable narrative to rely on, with no sustained permission for you to narrate, you feel yourself crowded out and silenced. No permission to narrate. Anything further you might wish to say or do is likely to become "terrorism.,"210

Finally, any opposition to the unjustified use of the terrorism label seems almost impossible, if one wants to avoid being placed in the same category as the 'terrorist' enemy. As we recall George W. Bush's oft repeated statement launching the new War on Terror after the attacks on September 11, "Either you are with us or you are with the terrorists."

The extent of the power of the 'terrorism' label, is summed up distinctly by Robert Fisk who observed that it

has become a plague on our vocabulary, the excuse and reason and moral permit for state-sponsored
violence - our violence - which is now used on the innocent of the Middle East ever more
outrageously and promiscuously. Terrorism, terrorism, terrorism. It has become a full stop ... the be-
all and end-all of everything that we must hate in order to ignore injustice and occupation and
murder on a mass scale. Terror, terror, terror, terror. It is a sonata, a symphony, an orchestra turned
to every television and radio station and news agency report, the soap-opera of the Devil, served up

${ }^{209}$ Ibid., p. 257.
${ }^{210}$ Ibid., p. 356. 
on prime-time or distilled in wearyingly dull and mendacious form by the right-wing 'commentators' of the American east coast or the Jerusalem Post or the intellectuals of Europe. Strike against Terror. Victory over Terror. War on Terror. Everlasting War on Terror. Rarely in history have soldiers and journalists and presidents and kings aligned themselves in such thoughtless, unquestioning ranks. ${ }^{211}$

It must be noted here that the present discussion of the misuse of terrorism accusations as a power tool in the Palestine-Israeli conflict is not to say that terrorist acts have not been committed by Palestinian factions. Nor should such acts go without strong condemnation and punishment. Whereas the right to self-defense and resistance to an illegal occupation should never be denied, the killing of innocent Jewish children in a restaurant in Jerusalem, along with other similar acts, is clearly unacceptable. At the same time, these crimes must be put in the necessary socio-historical context, not as to downplay them, but in order to comprehend the complex situation. For indeed the utter desperation of the Palestinians, out of which the motivation for carrying out such cruel and violent acts develops, has been given minimal attention in public Western discourse. Its adherents are thus missing a point which is key to understand and unravel the Palestine-Israeli conflict.

Whereas the Palestinian resistance has become synonymous with terrorism, what is entirely ignored in the public discourse is the Jewish 'share' in using acts of terrorism to achieve political goals. Zionist terrorism was first utilized under the British Mandate to fight both Arab resistance as well as British restrictions on Jewish immigration. It is indeed ironic that the State of Israel, which now justifies its expansionary, offensive wars against the Palestinians and Lebanese with its claims to fight the 'war on terror', was established largely with the aid of terrorist campaigns.

\footnotetext{
${ }^{211}$ Fisk, op. cit., p. 464.
} 
Even more ironic is the fact that the most notorious and influential leaders of the terrorist groups active throughout the 1930s and 1940s, until the objective of an independent Jewish state was achieved, were later to become leading, internationally respected politicians. Most notable is the case of Menachem Begin, Nobel Peace Prize laureate of 1978, who in his early years was the leader of the Irgun and as such responsible for the bombing of the headquarters of the British military administration in Jerusalem, the Kind David Hotel, in $1946 .{ }^{212}$ Killing 91 people and leaving many more wounded, the attack was the biggest terrorist action committed by the Irgun, although by no means the only one. The organization regularly abducted British military officials and executed them in such a brutal manner prompting the London Times to comment: "The bestialities practiced by the Nazis themselves could go no further." ${ }^{213}$ The Irgun was also, together with the terrorist Stern Gang, involved in the massacre of Deir Yassin and other Palestinian villages during the ethnic cleansing in 1947/48.

The use of terrorist measures was by no means abolished with the establishment of the Israeli state, for the building of Jewish settlements in the occupied territories has been accompanied by perpetual acts of settler violence against Palestinian civilians. Israeli fundamentalist groups, first and foremost Gush Emunim, with which some 35\% of settlers are affiliated, have strongly rejected the accords of Oslo and responded with violence, fearing that a peace agreement would lead to the dismantling of the settlements. ${ }^{214}$ The bloodiest act of settler violence was the 1994 massacre in Hebron, where Baruch Goldstein, a member of the fundamentalist group Kach, killed 29 Muslim worshippers and wounded dozens more in the

\footnotetext{
${ }^{212}$ Fisk reports the King David Hotel's video of its own history to take great pride in the bombing conducted by Menachim Begin.

${ }^{213}$ Qtd. in Morris, Righteous Victims, op. cit., p. 181.

${ }^{214}$ Reuveny, op. cit., p. 364.
} 
Ibrahimiya Mosque. ${ }^{215}$ Israel responded to the escalating conflict by imposing curfews and closures on the territories which in return spurred further terrorist acts by both Palestinians and Israeli settlers. As a result, Prime Minister Yitzhak Rabin was assassinated by an Israeli fundamentalist, Yigal Amir, who believed that "God wanted Rabin dead in order to stop the Oslo process." As one scholar has argued, the settler violence and their repeated warnings of an Israeli civil war, if settlements were abolished, explain the failure of the Oslo peace process and Israel's reluctance to agree to an evacuation of the settlements. ${ }^{216}$

\section{Conclusion}

This chapter examined various fields of dissemination and production of knowledge in order to understand how they are utilized by the Zionist enterprise to legitimize its practice of dispossession. As each field was analyzed in its effectiveness as a social factor, or Relation, in the dialectical sense we can now see how the scalar fix of knowledge has not only shaped the common view of Palestine, but indeed helped to scale the historiography of the Palestine-Israeli conflict and to deliberately suppress the formation of a distinct, authentic Palestinian narrative.

The power of the scalar fix of knowledge becomes apparent when considering the 2008/09 war on Gaza, which presents a continuation of the perpetual denial of truth about the dispossession of the Palestinian people. As the many violent outbreaks of the conflict over the decades, the presentation thereof in public discourse fails completely to place a single event into the overall picture. It is this scalar fix of our conception of the socio-spatial environment, which has brought us to a point where the opening of the borders to Gaza for a few days is considered a great achievement, or the release of ONE Israeli soldier captured by Hamas is the decisive factor

\footnotetext{
${ }^{215}$ Reuveny, op. cit., p. 365; Morris, Righteous Victims, op. cit., p. 624.

${ }^{216}$ Ibid.
} 
of peace negotiations which are to end the blockade of Gaza which has imprisoned 1.5 million people for nearly two years.

To the extent that education, media representations and public discourse shape our understanding of things and affect our levels of comfort or insecurity, an analysis of the scalar fix of knowledge exposes acts of dispossession that go beyond the absolute, material space of land and water rights and the conceptualized space of maps portioning the land of Palestine, issues which were addressed in chapters 4 and 5. The scalar fix of knowledge indeed infiltrates the lived space that often forms images and opinions about our environment and thus affects our social behavior and activities. In other words, our analysis has taken us further down and to the right of Harvey's matrix of spatialities, i.e. in the realms of the lived and relational spaces. This allows us to proceed to the core of the issue: the Zionists' aim to oppress any efforts to establish a genuine, authentic Palestinian social structure and thus to prevent the consolidation of a Palestinian identity. 


\title{
CHAPTER 7:
}

\section{THE SCALAR FIX OF IDENTITY}

\begin{abstract}
Oh past, do not change us... the further away we move from you! Oh future: do not ask us: who are you? And what do you want from me? We too have no clue. Oh present, bear with us a little, we are no more than dreary passers by!

Identity is our legacy and not our inheritance; our invention and not our memory.

Mahmoud Darwish ${ }^{217}$
\end{abstract}

In extension to the analysis from the previous chapter, the final section of the analysis part of this thesis investigates the notion of identity in its function as a scalar fix. As I have argued in chapter 2, the power of identity should not be underestimated, for the Zionist course of action over the decades, as well as the Palestinian response to it, can be ascribed to a large extent to the practice of scaling identity. Realizing the potential of a solidly constructed identity, the Zionist/Israeli objective has been to actively dispossess the Palestinians of their identity. On the other hand, the consolidation of a strong Zionist identity has served as a scalar fix which has been essential as a tool of domination. This chapter will examine both these aspects of the scalar fix of identity. In doing so, identity is understood as a social Relation in the dialectical sense, making it clear that the consciousness of identity determines people's social action, while at the same time identity is shaped through the impressions of a constantly changing social environment.

The scalar fix of identity is reinforced through the notion of an ideology of difference which manifests itself in discourse and the use of certain terminology (see chapter 6), and draws on fears and emotions that feed into the perception of 'us' vs. the 'other'. In that sense, the

\footnotetext{
${ }^{217}$ From Darwish, Mahmoud, "You, as of now, are someone else!"
} 
awareness of the difference between Zionist Jews and non-Jews - artificially enhanced through the scaling of the particular knowledge about one another - translates into the differential treatment of Jews and Palestinians in all types of spatiality. Building on this notion of difference, the Zionist-Jewish identity has assumed superiority over the Palestinians, forcing the latter into a permanent position of defense and resistance - thus creating a situation of permanent struggle which defines the Palestinian identity to a great extent.

As a consequence of this feeling of superiority, reinforced by the Zionist notion of having the undeniable right to the land of Palestine, the dispossession of the indigenous Arabs is justified and undisputed in Zionist historiography. From the very beginning, the Zionist movement set out to establish an exclusive society that distinguishes between Jews and nonJews, the ultimate objective being the annihilation of the latter to provide Lebensraum (living space) for the former. It must be noted here that this notion of a Jewish identity is not all together confined to the religious tradition of Judaism. On the contrary, it is primarily based on the Zionist ideology which bears little resemblance with the practice of the Judaic faith. ${ }^{218}$ Thus, complementary to political, economic and military means of dispossession, the Zionist project has been supported by a narrative designed to make the infamous slogan of 'a land with no people for a people without land' become true. While considerable efforts have been made to suppress the consolidation of a Palestinian identity, this Zionist tale has been nurtured to support and enhance a Jewish identity as conceived through the lens of Zionism.

In that sense, the State of Israel was established as a Jewish state for all Jewish people, including both residents of Israel and the diaspora. ${ }^{219}$ This Zionist-Jewish identity is justified on religious, traditional and historical grounds, whereby the theological claim that the Jews are the

\footnotetext{
${ }^{218}$ In fact, many Jews throughout the world distance themselves from Zionism, claiming that it does not represent their religion.

${ }^{219}$ See Chomsky, op. cit.
} 
"chosen people" who have a right to the "Holy Land" reinforces the sequence of events representing more than 2000 years of suffering and exile - from the story of slavery in ancient Egypt, to centuries of oppression by various empires in the Middle East, to the more recent tragedy of the pogroms in Eastern Europe and finally Germany - which is thought to be the unique fate of the Jewish people. ${ }^{220}$ This "collective memory of persecution" 221 - has been held up to consolidate the Zionist narrative and gain support also among non-Zionist groups. In the face of changing spatial and historical contexts coupled with waves of Palestinian resistance, the Zionists had to continuously reinforce and reassert their own history - a history of persecution culminating in the Holocaust - assuming that it legitimize their claims to the land of Palestine and their course of action in Israel. A great many Holocaust survivors, their children and grandchildren hold on to the narrative of their agony and continue to live "in that time". ${ }^{222}$ Thus, the Holocaust - the term being trademarked through capitalization - itself becomes a manifestation, a tragedy that does not compare to any other mass slaughter of any other people. Hardly ever do we hear the word used in connection with other acts of ethnic cleansing such as those in Armenia, Rwanda and Darfur, or that of the Palestinians in 1948. The notion of the Holocaust thus becomes an immensely powerful tool in the Israeli narrative.

To the very extent that the Zionists have consolidated their narrative, the Palestinians have been deprived of their history, being denied the "permission to narrate."223 What has translated into a conceived non-existence of the Palestinian people evolved in different stages, whereby the transition from one to another has been - similar to the evolution of the Zionist narrative - determined by the socio-spatial circumstances and the real Palestinian existence - i.e.

\footnotetext{
${ }^{220}$ Said, Politics of Dispossession, op. cit., p. 88.

${ }^{221}$ See Stork, J. and S. Rose. (1974). Zionism and American Jewry. Journal of Palestine Studies, 3 (3), 39 - 57.

${ }^{222}$ Fisk, op. cit., p. 458.

${ }^{223}$ Said, Politics of Dispossession, op. cit., p. $247 \mathrm{ff}$.
} 
the lived space of Palestine with all its anger and frustration, fear and desperation, but also hope and patience. As long as the Palestinian resistance did not pose a considerable threat to the Zionist project, the Palestinian people could be widely ignored. It was only after the rise a formidable resistance movement, which could not be easily defeated, that the disregard for the Palestinians was turned into more aggressive efforts of denial in mainstream media and public discourse (see chapter 6). After such efforts, along with military means, failed to curtail the Palestinian resistance - which escalated in the first intifada - the tactical denial took on a new shape in the pretense of 'acknowledgement' and willingness to 'compromise'. The 'Peace Process' came to the fore, promising the Palestinians equal treatment and sovereignty at last. Yet the Palestinians were forced to make considerable concessions so that the 'Peace Process' resulted in the very opposite of what they had demanded: the consolidation of the Zionist project and the destruction of any hopes for Palestinian sovereignty.

The groundwork for denial of Palestinian identity and self-determination was laid during the days of British rule, when Palestinians were not referred to as Palestinians or Arabs but as "the non-Jewish communities." ${ }^{224}$ In that sense, the very term 'Mandate of Palestine' is in fact misleading, as the British did not carry out their mandate to develop a state according to selfdetermination of the indigenous people. It was rather a Mandate of Zionism, for the Zionist project was allowed to flourish, building a quasi state within the British Mandate, at the expense of the Palestinians.

This denial was further facilitated by the lack of cohesion of the Palestinian society, which had been highly fragmented from the beginning due to competing loyalties to class, religion, a city or region. While recognizing the Zionist threat as early as the late $19^{\text {th }}$ century,

\footnotetext{
${ }^{224}$ Khalidi, Palestinian Identity, op. cit., p. 23.
} 
Palestinians failed from the very beginning to unite and overcome their internal schisms. ${ }^{225}$ There is no doubt this problem has had a debilitating impact on the formation of sound, genuine Palestinian leadership, not to mention the development of a meaningful resistance that goes beyond the use of violence.

This notion of a lacking Palestinian narrative is not to downplay the continuous representation of 'Palestinianism' through a small but respectable group of intellectuals, artists and activists who have been trying to reach out to the public with their cause. To be sure, Palestinian writers and scholars, along with those favorable of the Palestinian cause, have continuously given lectures and published books and articles, yet most of them address merely one issue of the overall conflict. Indeed, as Said notes, a comprehensive Palestinian narrative presented by Palestinians themselves - has not been permitted to enter public discourse in the West. $^{226}$ To the extent that holistic accounts have been attempted, they are usually written under a certain perspective, based on a particular paradigm that fails to embrace the evolution of the conflict as a whole. Hence, such tireless efforts pale alongside the compelling mass of negative representations of the Palestinian people, peaking in its alleged non-existence.

What we are left with are fractions of an incomplete story of a people whose existence has been denied for decades, and whose identity has never been allowed to fully unfold. These fragments are often the result of attempts to build this Palestinian narrative, the result of feeling the need to explain the story of the Palestinians 'from scratch' whenever the issue of the conflict is addressed one way or another. Ironically, it is especially at times of major violent outbreaks,

\footnotetext{
${ }^{225}$ Ibid., pp. 24/5.

${ }^{226}$ Said, Politics of Dispossession, op. cit., pp. $253 \mathrm{ff}$.
} 
defined by Israel's usual, disproportionate military preponderance over stone-throwing schoolchildren and handmade rockets, that the narrators of such fragments raise their voices. ${ }^{227}$

Why does the Palestinian cause not get heard? Or if it does, why is not treated with the due respect and sincerity? The few scholars who did point towards the striking similarities of the Palestinian situation to that of American Indians or Apartheid South Africa (for indeed, Gaza has been referred to as Israel's "Soweto" 228 ) have gone largely unheard. As Edward Said observed, the separation between Jews and non-Jews - both in physical space and the representation thereof - has "been translated ideologically into a separation of that practice from all other similar practices. ${ }^{229}$ In other words, it is due to the scalar fixes of dispossession deliberately designed by the dominant forces, that the highly unequal treatment of Palestinians has not found much recognition among policy makers and intellectuals in the West. Unless this key issue is fully recognized and appreciated, there is no end to the Israeli-Palestine conflict in sight.

I therefore conclude that the scalar fix of identity lies at the core of Israel's perpetual policy of dispossession which it has carried out with virtual impunity. This only becomes clear if we approach the issue from a dialectical perspective: the power of scaling identities, along with other scaling practices that affect the psychologies of the lived space (i.e. anxieties, fears, desires, dreams and memories), has a significant impact on how we conceptualize and experience the world around us. In order to further our understanding of a complex conflict as that of between Israel and Palestine, these are the issues further research on the subject should focus on.

\footnotetext{
${ }^{227}$ Dina Jadallah-Taschler's article, The Struggle of an Un-People, op. cit., is but one example.

${ }^{228}$ Sara Roy, op. cit., p. 251.

${ }^{229}$ Said, Politics of Dispossession, op. cit., p. 89.
} 


\section{CHAPTER 8: CONCLUSION}

\subsection{Review of the Objective}

The aim of this thesis was to examine the use of scalar fix as a deliberate function of the all-encompassing dispossession of the Palestinian people and, hence, as a means of consolidating power. A conceptual framework was therefore developed which linked the geographical concept of scalar fix to the process of accumulation by dispossession, which Harvey defined as one of the four key conditionalities of uneven geographical development. In addition to the theory of uneven development, this concept also adopted Harvey's matrix of multiple spatialities in order to expand the use of scalar fix beyond the sphere of absolute space. Four different types of scalar fix, in their function of consolidating power, were identified:

1) scalar fix of legislation and policy making

2) scalar fix of networking

3) scalar fix of knowledge

4) scalar fix of identity

These four scalar fixes were applied to the case of Palestine in order to analyze the underlying processes of dispossession.

Both the conceptual framework and the analysis used dialectics as methodology. Given its potential to expose underlying processes and causes of social change which might not be revealed using common methodology in social studies, dialectics was found to be the most suitable approach to a conflict as complex as that of Israel and Palestine.

\subsection{Findings and Contributions}

The thesis contributes to studies in human geography, in particularly studies of uneven geographical development, with respect to theory as well as analysis of a specific case. From a 
conceptual perspective, this study expanded on the existing concept of scalar fix by applying it to Harvey's multiple spatialities. In doing so, scalar fix proves to be an even more powerful tool than shown in previous studies. A second theoretical contribution is the linkage of scalar fix to the act of dispossession, a concept which furthers our understanding of the processes of uneven development.

Using this framework to investigate the situation in Palestine, the thesis revealed some of the methods used and efforts made by the dominating powers - the Zionist regime in Israel and the United States - to legitimize Israel's sovereignty and to suppress the formation of Palestine as a coherent, functioning social entity. A detailed analysis of each of the four types of scalar fix showed that they are all significant to Israel's consolidation of power at the expense of the Palestinian people. While it was shown that the formulation of legislation and policies have scaled the territorial organization and social environment of Palestine in absolute, relative and conceptualized space, the study also exposed the effectiveness of the practice of scaling knowledge and manipulating people's perception, thus affecting the lived space of emotions such as fear, hope and desire. Furthermore, the investigation of the impact of networking showed that this scalar fix is closely related to the scalar fix of legislation, for many documents and policies that proved to be decisive might not have come about without the influence from firmly established networking relationships. Similarly, the analysis revealed a close interrelation of the scalar fixes of knowledge and identity as both influence each other. Moreover, both scalar fixes have impact on - and are affected by - the sphere of lived space.

Finally, this thesis highlighted the utility of dialectics in several ways. As regards the conceptual framework, the relational perspective of dialectics allowed it to conceptualize space in its multiple facets and to expand scalar fix beyond the realm of the absolute. Furthermore, the 
dialectical modes of abstraction facilitated a comprehensive approach to analysis which revealed the immense power and extent of the various scalar fixes utilized to dispossess the Palestinians, reaching into all aspects of socio-spatial awareness. If viewed through the dialectical lens the precarious situation of Palestinians, especially the nearly 5 million living in refugee camps, can be put into perspective and understood as the result of more than a century of deliberate acts of dispossession, while at the same time accounting for the shortcomings of their social structures and struggles.

\subsection{Constraints of the Study}

The thesis shows several constraints which are primarily a result of the limited scope of a master thesis. First, given the complexity of the Palestine-Israeli conflict, only a select few scalar fixes could be identified and addressed. As indicated in chapter 3, there are scalar fixes associated with all intersections of Harvey's spatial matrix which need to be identified and examined in further research.

Moreover, the scalar fixes investigated in this thesis have been only partially addressed and require more in-depth analysis, particularly the scalar fix of networking and the scalar fix of identity. With respect to Zionist policies towards Palestine, I suspect that networks as scalar fix take on more dimensions than what has been examined in this study. For instance, Jewish financial networks have been involved in funding immigration to Palestine, especially in the prestate era. In addition, the perpetual involvement of former Haganah, Irgun and Stern members as well as their descendants in high ranking positions of Israeli politics indicates a well established elitist network. 
The scalar fix of identity opens up a rather broad field of analysis which could only be hinted at within the framework of this thesis. Additional knowledge with respect to the psychology of identity and identity formation may be required in order to facilitate further investigation of its function as scalar fix.

Finally, the dialectics applied to the conceptual framework and analysis in this thesis is largely based on Ollman's work, Dance of the Dialectic. Other paradigms of dialectics - which may open up additional approaches to analysis - are thus not taken into account and might place restrictions on our potential understanding of the subject matter of this thesis.

\subsection{Recommendations for Future Research}

Drawing on these constraints several topics for further research become apparent. In order to expand on the concept of scalar fixes of multiple spaces, future research is required to identify additional forms of scalar fix associated with the intersections of Harvey's spatial matrix. This involves further examination of the processes of accumulation by dispossession, as well as more in-depth analysis of the multiple spaces.

Moreover, as mentioned above, both the scalar fix of networking and the scalar fix of identity provide subjects for further research. In order to gain a full understanding of their effectiveness and potential to dispossess the Palestinians, both scalar fixes need to be examined in more detail. While adhering to the dialectical approach, further study of the scalar fix of networking could involve textual analysis of documents including internal correspondence, meeting minutes and memoranda that illuminate the level of interaction and collaboration within a certain network such as the Jewish financial elite. Future research of the scalar fix of identity could address how identity is expressed through Palestinian arts and literature such as that of the 
late Mahmoud Darwish. Another research topic pertaining identity could examine how the scaling and dispossession of identity affects the psychologies of the lived space of Palestinians and how the resulting fears, anxieties, desires, dreams and memories translate into social action and resistance to Israeli oppression.

In conclusion, this thesis is merely the beginning of a dialectical approach towards understanding the dispossession of the Palestinian people and its role in the overall conflict between Israel and Palestine. Considering the utility of dialectics for both theoretical framework and analysis, it is essential that any future research with the objective to further our understanding of the situation in Palestine approaches the subject from a dialectical perspective. Only then can we account for the changes to a social structure without losing sight of the overall picture. Only with dialectics can we reveal acts of "stealing the commons from under the goose" rather than merely focusing on studies of "stealing the goose from the commons." 


\section{APPENDIX A}

The following excerpt was taken from Khalidi, W. (1988). Plan Dalet: Master Plan for the Conquest of Palestine. Appendix B. Journal of Palestine Studies, 18 (1), 24 - 33.

\section{Text of Plan Dalet (Plan D), 10 March 1948: General Section}

The text that follows is translated from Sefer Toldot Hahaganah [History of the Haganah], vol. 3, ed. by Yehuda Slutsky (Tel Aviv: Zionist Library, 1972), Appendix 48, pp. 1955-60.

\section{Introduction}

(a) The objective of this plan is to gain control of the areas of the Hebrew state and defend its borders. It also aims at gaining control of the areas of Jewish settlement and concentration which are located outside the borders [of the Hebrew state] against regular, semi-regular, and small forces operating from bases outside or inside the state.

(b) This plan is based on three previous plans:

1. Plan B, September 1945.

2. The May 1946 Plan *

3. Yehoshua Plan, 1948.**

(c) Since these plans were designed to deal with the situation inside the country (the first two plans deal with the first phase of incidents, while the third plan deals with the possibility of invasion by regular armies from the neighboring countries), the aim of Plan D is to fill the gaps in the previous

-This is plan Gimmel or Plan C

-This is an early version of Plan D, so-called after Yehoshua Globerman, a Haganah commander killed in early December 1947. Plan D itself was finalized on 10 March 1948. 
three plans and to make them more suitable for the situation expected to obtain at the end of British rule in the country.

\section{Basic Assumptions}

This plan is based on the following basic assumptions:

\section{(a) The Enemy}

1. Expected composition of forces:

- The semi-regular forces of the Liberation Army affiliated with the Arab League, which operate from already occupied bases or bases to be occupied in the future.

- The regular forces of neighboring countries, which will launch an invasion across the borders, or will operate from bases inside the country (the Arab Legion").

- Small local forces which operate, or will operate, from bases inside the country and within the borders of the Hebrew state.

All three forces will be activated at the same time in accordance with a joint operational plan, and will sometimes engage in tactical coordination.

2. Actual operations expected from the enemy:

-Isolation and, if possible, occupation of the eastern Galilee, western Galilee, and the Negev.

-Infiltration into the heart of the area of Sharon and Emek Hefer ${ }^{\prime \prime}$ in the direction of Qalqiliyyah-Herzliya and Tulkarm-Netanya, roughly.

- Isolation of the three major cities (especially Tel Aviv). $\dagger$

-Disruption of food supply lines and other vital services such as water, electricity, etc.

3. Expected tactical methods:

-Attacks by the regular and semi-regular forces on settlements, using heavy infantry weapons, as well as field artillery, armored vehicles, and the air force.

-Air strikes against centers within our cities (especially Tel Aviv).

- Harassment operations carried out by small forces against transportation arteries and settlements to give the operations mentioned above direct

-This was a British-commanded and financed army of King 'Abdallah's Transjordan, units of which served in Palestine under British army orders until the end of the mandate on 15 May 1948.

* Sharon is the coastal plain between Haifa and Tel Aviv, Emek Hefer being its central section (in Arabic Wadi al-Hawarith).

†The two others are Jerusalem and Haifa. 
or tactical support. These forces will also carry out sabotage operations against vital economic facilities and terrorist raids within cities.

\section{(b) The Authorities}

This plan rests on the general assumption that during its implementation, the forces of the [British] authorities will not be present in the country.

In the event that British forces continue to control certain bases and areas, the plan must be modified to deal with this situation in these areas. Additional instructions will be issued in this regard.

\section{(c) International Forces}

This plan rests on the assumption that there will be no international forces stationed in the country which are capable of effective action.

\section{(d) Operational Objectives}

1. Self-defense against invasion by regular or semi-regular forces. This will be achieved by the following:

-A fixed defensive system to preserve our settlements, vital economic projects, and property, which will enable us to provide governmental services within the borders of the state (based on defending the regions of the state on the one hand, and on blocking the main access routes from enemy territory to the territory of the state, on the other).

-Launching pre-planned counter-attacks on enemy bases and supply lines in the heart of his territory, whether within the borders of the country [Palestine] or in neighboring countries.

2. Ensuring freedom of military and economic activity within the borders of the [Hebrew] state and in Jewish settlements outside its borders by occupying and controlling important high-ground positions on a number of transportation arteries.

3. Preventing the enemy from using frontline positions within his territory which can easily be used for launching attacks. This will be effected by occupying and controlling them.

4. Applying economic pressure on the enemy by besieging some of his cities in order to force him to abandon some of his activities in certain areas of the country. 
5. Restricting the capability of the enemy by carrying out limited operations: occupation and control of certain of his bases in rural and urban areas within the borders of the state.

6. Controlling government services and property within the borders of the state and ensuring the supply of essential public services in an effective manner.

\section{Assignment of Duties}

In view of the operational objectives outlined above, the various armed services are assigned the following duties:

(1) Strengthening the fixed defensive system designed to defend the zones, and coordinating its deployment on the regional level. In addition, the main enemy access routes to the lands of the state must be blocked through appropriate operations and measures.

(2) Consolidation of the defensive apparatus.

(3) Deployment in major cities.

(4) Control of the main transportation arteries country-wide.

(5) Encirclement of enemy cities.

(6) Occupation and control of frontline enemy positions.

(7) Counterattacks inside and outside the borders of the country.

\section{(a) The Fixed Defensive System}

1. The fixed defensive system in rural areas depends on two main factors: using protected areas for the purpose of defending the circumference, on the one hand, and blocking main transportation routes used by the enemy, on the other hand.

2. The security arrangements pertaining to the zones in rural areas, which were originally designed to repel small enemy forces, must be modified in terms of planning and reinforcement to suit the tactical measures expected to be employed by semi-regular or regular enemy forces. This will be effected according to instructions issued by the operations branch in charge of defense and planning in rural areas.

3. In addition, if we take into consideration the tactical measures expected to be employed by the enemy, efforts must be made to make a transition from a positional defense to a regional defense, so that the unit of defense is the region and not the zone.

4. In order to achieve this objective, the following steps must be taken: 
a) Transformation of the regional staff from an administrative staff to a general staff (selection of a location, setting up a communications network, etc.)

b) Formation of a regional mobile reserve, to be recruited from the forces appointed to the zones, which would reinforce the forces or carry out counterstrikes in the zones within each region according to pre-arranged plans.

c) Adaptation and incorporation of the plans concerning fortification and opening fire in the zones to those of the region, as far as possible, taking into consideration geographical circumstances and types of weapons used. These plans must also be coordinated with the operations of the regional mobile reserves.

5. Settlements which because of their geographical location cannot be included in a fixed regional defense plan must be organized into local defense zones. Accordingly, they must be equipped to block transport roads used by the enemy, or if tactical circumstances permit, to control the heights, setting up fortifications and barricades and laying mines, etc. This will be done in addition to activating the zone's defensive apparatus. Additional forces must be assigned to carry out these duties, as will be detailed below. These specifications also apply to isolated regions.

6. Blocking the main enemy transportation routes.

a) The main enemy transportation routes which link his lands to the lands of the state, such as roads, bridges, main passes, important crossroads, paths, etc. must be blocked by means of: acts of sabotage, explosions, series of barricades, mine fields, as well as by controlling the elevations near roads and taking up positions there.

b) A system of barricades must be set up in addition to the fixed defensive system. The tactical plans concerning barricades must be adapted to and coordinated with the defensive plans concerning the zones located near these barricades. They must also be coordinated with the regional defense plans if this is possible from the geographical point of view.

\section{(b) Consolidation of Defense Systems and Barricades}

The following operations must be carried out if the fixed defensive system is to be effective and if the rear of this system is to be protected:

1. Occupation of police stations.

"These "police stations" were in fact fortresses, fifty of which were built by the British throughout Palestine after the Arab rebellion of 1936-39 in order to control the Arab population. 
2. Control of government installations and provision of services in each and every region.

3. Protection of secondary transportation arteries.

4. Mounting operations against enemy population centers located inside or near our defensive system in order to prevent them from being used as bases by an active armed force. These operations can be divided into the following categories:

-Destruction of villages (setting fire to, blowing up, and planting mines in the debris), especially those population centers which are difficult to control continuously.

-Mounting combing and control operations according to the following guidelines: encirclement of the village and conducting a search inside it. In the event of resistance, the armed force must be wiped out and the population must be expelled outside the borders of the state.

The villages which are emptied in the manner described above must be included in the fixed defensive system and must be fortified as necessary.

In the absence of resistance, garrison troops will enter the village and take up positions in it or in locations which enable complete tactical control. The officer in command of the unit will confiscate all weapons, wireless devices, and motor vehicles in the village. In addition, he will detain all politically suspect individuals. After consultation with the [Jewish] political authorities, bodies will be appointed consisting of people from the village to administer the internal affairs of the village. In every region, a [Jewish] person will be appointed to be responsible for arranging the political and administrative affairs of all [Arab] villages and population centers which are occupied within that region.

\section{(c) Deployment in Major Cities}

Positions will be taken in the large cities according to the following principles:

1. Occupation and control of government facilities and property (post offices, telephone exchanges, railroad stations, police stations, harbors, etc.)

2. Protection of all vital public services and installations.

3. Occupation and control of all isolated Arab neighborhoods located between our municipal center and the Arab municipal center, especially those neighborhoods which control the city's exit and entry roads. These neighborhoods will be controlled according to the guidelines set for 
combing villages. In case of resistance, the population will be expelled to the area of the Arab municipal center.

4. Encirclement of the central Arab municipal area and its isolation from external transportation routes, as well as the termination of its vital services (water, electricity, fuel, etc.), as far as possible.

\section{(d) Control of Main Transportation Arteries on the Regional Level}

1. Occupation and control of locations which overlook main regional transportation arteries, such as police stations, water pumps, etc.

These elevated locations will be transformed into fortified surveillance posts to be used, when the need arises, as bases for a mobile defensive force. (In many cases, this operation will be coordinated with the occupation of police stations, which aims at consolidating the fixed defensive system.)

2. Occupation and control of Arab villages which constitute a serious obstruction on any of the main transportation arteries. Operations against these villages will be carried out according to the specifications given under the item pertaining to the combing of villages.

\section{(e) Enemy Cities Will Be Besieged according to the Following Guidelines:}

1. By isolating them from transportation arteries by laying mines, blowing up bridges, and a system of fixed ambushes.

2. If necessary, by occupying high points which overlook transportation arteries leading to enemy cities, and the fortification of our units in these positions.

3. By disrupting vital services, such as electricity, water, and fuel, or by using economic resources available to us ${ }^{*}$ or by sabotage.

4. By launching a naval operation against the cities that can receive supplies by sea, in order to destroy the vessels carrying the provisions, as well as by carrying out acts of sabotage against harbor facilities.

\section{(f) Occupation and Control of Frontline Enemy Positions}

Generally, the aim of this plan is not an operation of occupation outside the borders of the Hebrew state. However, concerning enemy bases lying directly close to the borders which may be used as springboards for infiltration into the territory of the state, these must be temporarily

-The meaning in the original is unclear. 
occupied and combed according to the above guidelines, and they must then be incorporated into our defensive system until operations cease.

Bases located in enemy territory which are intended to be temporarily occupied and controlled will be listed among the operational targets for the various brigades.

\section{(g) Counterattacks Inside and Outside the Borders of the State}

Counterattacks will be used as auxilliary measures for the fixed defensive system in order to abort the organized attacks launched by semi-regular and regular enemy forces, whether from bases inside the country or from outside the borders.

Counterattacks will be launched according to the following guidelines:

1. Diversionary attacks; i.e., while the enemy is launching an attack against one of our areas, [our forces will launch] a counterattack deep inside another area controlled by the enemy with the aim of diverting his forces in the direction of the counterattack.

2. Striking at transportation and supply routes deep inside enemy territory, especially against a regular enemy force which is invading from across the border.

3. Attacking enemy bases in his rear, both inside the country [Palestine] and across its borders.

4. Counterattacks will generally proceed as follows: a force the size of a battalion, on average, will carry out a deep infiltration and will launch concentrated attacks against population centers and enemy bases with the aim of destroying them along with the enemy force positioned there; alternatively, this force may split up to carry out secondary operations, such as acts of sabotage and diversion on the enemy's military transportation routes and arteries.

5. A detailed list of counterattacks will be included in the [list of] operational targets ${ }^{*}$ of the Strategic Mobile Force [PALMACH]. $\dagger$

\section{Duties of the Armed Services}

(a) Allocation of duties in the fixed defensive system:

\footnotetext{
See Appendix C, below.

"This list is not in the Hebrew original of this document.

†PALMACH is short for Plugot Machats, i.e., crushing battalions. By spring 1948, this force was made up of three brigades (Yiftach, Harel, and HaNegev) numbering just above 8,000 men. See Walid Khalidi, From Haven to Conquest (Washington: Institute for Palestine Studies, 1987), 861.
} 
1. The following duties are the responsibility of the Garrison Force $[\mathrm{KHIM}]^{*}$ : defense of the zones and of isolated and fortified posts and formation of the regional reserves.

2. Within the framework of the fixed defensive system, the Field Force $[\mathrm{KHISH}]^{*}$ are responsible for the following duties:

-Operations to block enemy transportation routes. For this purpose, every blocking operation will be assigned, on the basis of its importance and type, a specified Field Force unit whose size is appropriate to the nature of the mission.

- In addition, the Field Force brigade in question will be responsible for duties related to consolidating the fixed defensive system, as outlined in section 3 (b).

3. In special and exceptional circumstances, Field Force units may be positioned in the regions or zones, or in isolated and fortified positions, in order to reinforce zonal or regional defense. Efforts must be made to decrease the number of such cases, as far as possible.

4. In addition to the duties detailed above, the Field Force's responsibilities in the context of the fixed defensive system generally consist in mounting local counterattacks involving units no smaller than a company (larger units should be used if possible) against enemy units while they are attacking the fixed defensive system in order to block their lines of retreat and destroy them. These counterattacks will usually be launched from fixed operational bases which will be specified for the Field Force in the context of the duties for which it is responsible in the region as a whole.

These instructions require that the Field Force units be concentrated as much as possible, and not be divided up into secondary units.

5. The chain of command in the cases mentioned above will be in accordance with Addendum 1 to the Order concerning Regional Infrastructure, November 1947.

6. In circumstances in which the blocking system (which the Field Force is responsible for defending) is incorporated into the zonal or regional defensive system, the commander of the Field Force battalion concerned will appoint the commander in charge of the entire defensive system.

(b) 1. In addition to the duties assigned to the Field Force brigade in

"KHIM is short for Khayl Matzav, the second line troops. By fall 1947, they numbered about 32,000. See Khalidi, From Haven to Conquest, 862.

* KHISH is short for Khayl Sadeh, the front line troops. By 1 May 1948, they numbered about 30,000 .

See Khalidi, From Haven to Conquest, 861. 
question concerning the consolidation of the fixed defensive system, the brigade will also carry out the following duties:

- Consolidation of positions in the cities.

- Control of main transportation arteries country-wide.

-Encirclement of enemy cities.

-Occupation and control of enemy frontline positions. This will be effected in accordance with the operational duties assigned to the various Field Force brigades.

In order to carry out one or all of these duties, the supreme command can assign units of the Strategic Mobile Force [PALMACH], which constitute the country-wide reserves, to the Field Force.

2. During the implementation of joint missions with the Field Force, units of the Strategic Mobile Force [PALMACH] will fall under the command of the Field Force brigade that controls the area in which these units are operating.

3. After completion of the mission, the units of the Strategic Mobile Force [PALMACH] will rejoin the country-wide reserves.

4. Efforts must be made to ensure that the period during which units of the country-wide reserves are assigned to the Field Force is as short as possible.

(c) 1. The Strategic Mobile Force [PALMACH] is responsible for carrying out counterattacks inside and outside the borders of the country.

2. The supreme command may reduce the number of duties assigned to one or another of the Field Force brigades as it sees fit (i.e. those related to the siege of enemy cities, control of transportation routes and occupation of frontline positions) and allocate them directly to the Strategic Mobile Force [PALMACH] instead.

(d) The various departments and services of the general staff are required to complete the above planning instructions in their various areas of responsibility and to present the plans to the Field Force brigades.

\section{APPENDIX B}

The following case study is taken from the report, The Humanitarian Impact on Palestinians of Israeli Settlements and other Infrastructure in the West Bank (pp. 106-109), published by UN OCHA, 2007. 


\section{Al Jiftlik village, Jordan Valley: development inhibited}

Al jiftlik village has a population of approximately 5,500 Palestinians. It is located in the northern Jordan Valley (on the junction of Road 90 and 57) and surrounded by fertile land on which villagers have traditionally depended for growing crops and grazing animals.

Today, as the two maps on the following pages illustrate, the village is surrounded on all sides and fragmented by settlements, military bases, closed military areas, nature reserves, roads primarily for Israeli use and checkpoints. The two closest settlements, Argaman (established 1969) and Massu'a (1970) are home to 166 and I 40 Israelis respectively who cultivate extensive areas of land beyond the settlements' outer limits. ${ }^{10}$

Al jiftlik's livestock farmers now have limited areas on which to graze their animals. Traditionally, livestock have grazed and watered in the hills surrounding the village. However, because land has been confiscated for settlements and military bases, and most of the remaining land lies in closed military areas, grazing land is scarce and many natural springs cannot be reached. As a result, most livestock farmers are forced to buy expensive fodder.

Those farmers who continue to raise livestock and grow crops face delays at checkpoints and longer journey times to reach local markets such as those in Tubas and Tammoun. Perishable produce, such as meat and dairy products, risks spoiling before reaching market.

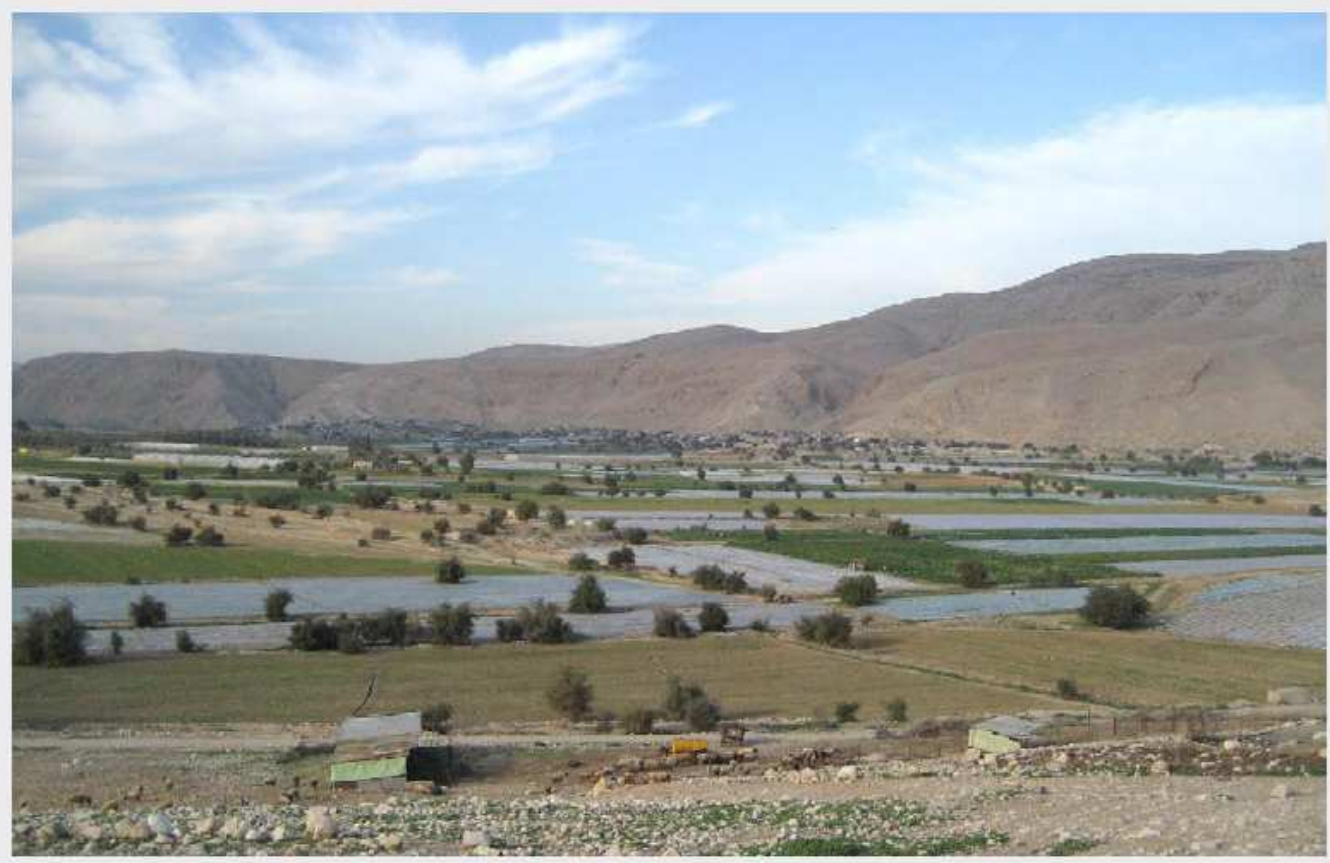

Al liftlik village lands. Photo by $O C H A, 2007$. 
Location of Al Jiftlik village
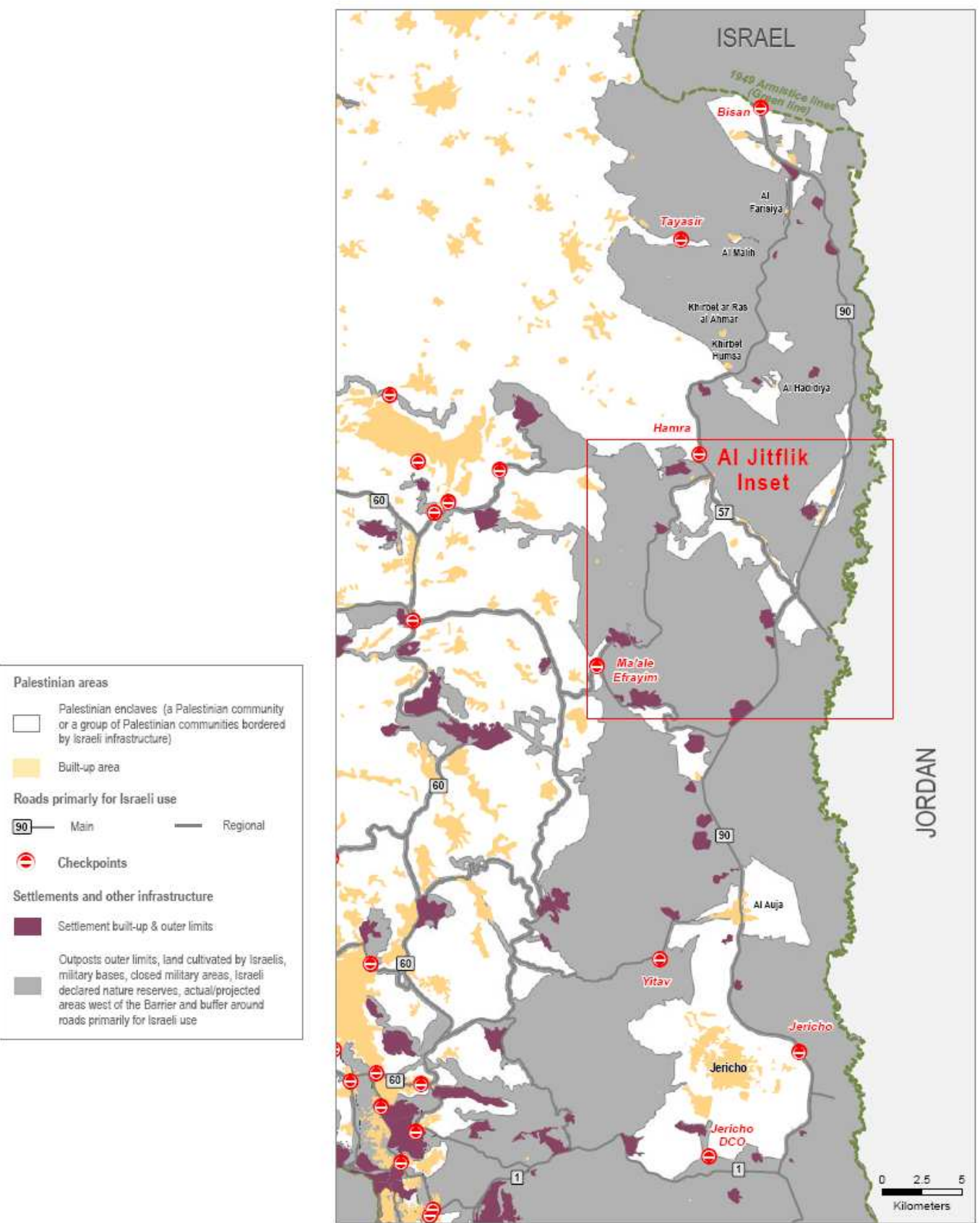
Al jiftlik is located in Israeli controlled Area C." New construction can only legally take place on the basis of an Israeli permit. These are extremely difficult to obtain. Only limited construction in the village has been approved by the Israeli authorities since 1967, resulting in overcrowding.

Buildings constructed without a permit risk being demolished by the IDF. Throughout 2005 and 2006, a total of 24 Palestinian structures were demolished in Al jiftlik. On 23 January 2007, the IDF demolished five shelters displacing 32 Palestinians, including 17 children. ${ }^{12}$

A positive development in 2006 was the approval of an Al jiftlik 'master plan' by the Israeli authorities. However, the area it covers is too small. It leaves approximately 2,000 residents, or about $40 \%$ of the population, outside the approved urban area. Construction of new houses (after appropriate permits are granted) can occur within the master plan. However, houses built after 1967 outside the perimeter of the plan are considered illegal and face the continued threat of demolition.

Only $25 \%$ of village residents are currently connected to an electricity network and the water network is in need of repair. The newly approved master plan will include electricity and water connection but only for residents within its borders. In contrast, the nearby settlements of Mekhora, Argaman and Massu'a, enjoy electricity, running water and sophisticated irrigation systems.

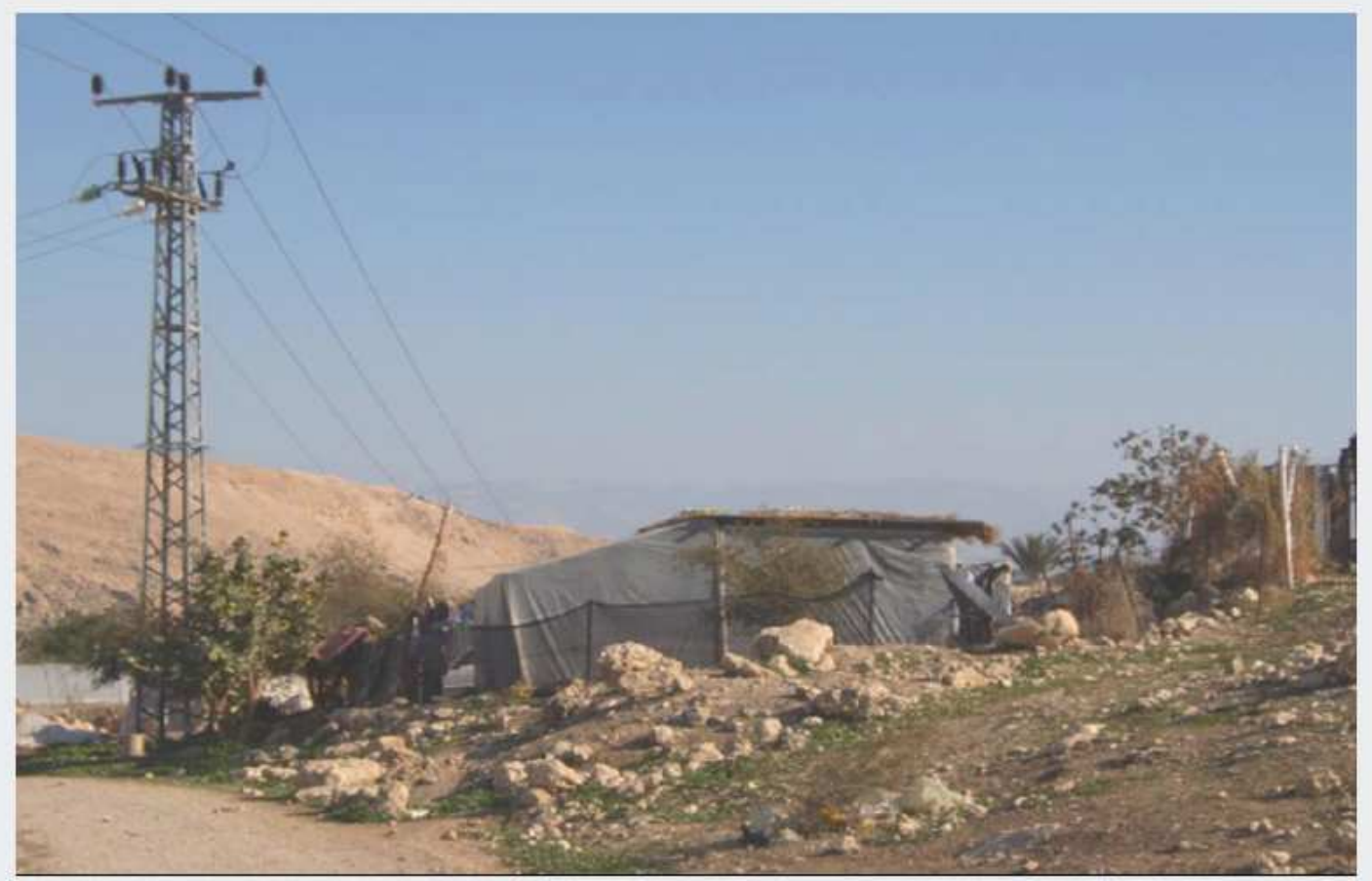

Power lines passing over A jiftlik village to provide electricty to nearby Israeli settlements. Photo by OCHA 2007. 
Al Jiftlik, a village encircled by Israeli infrastructure

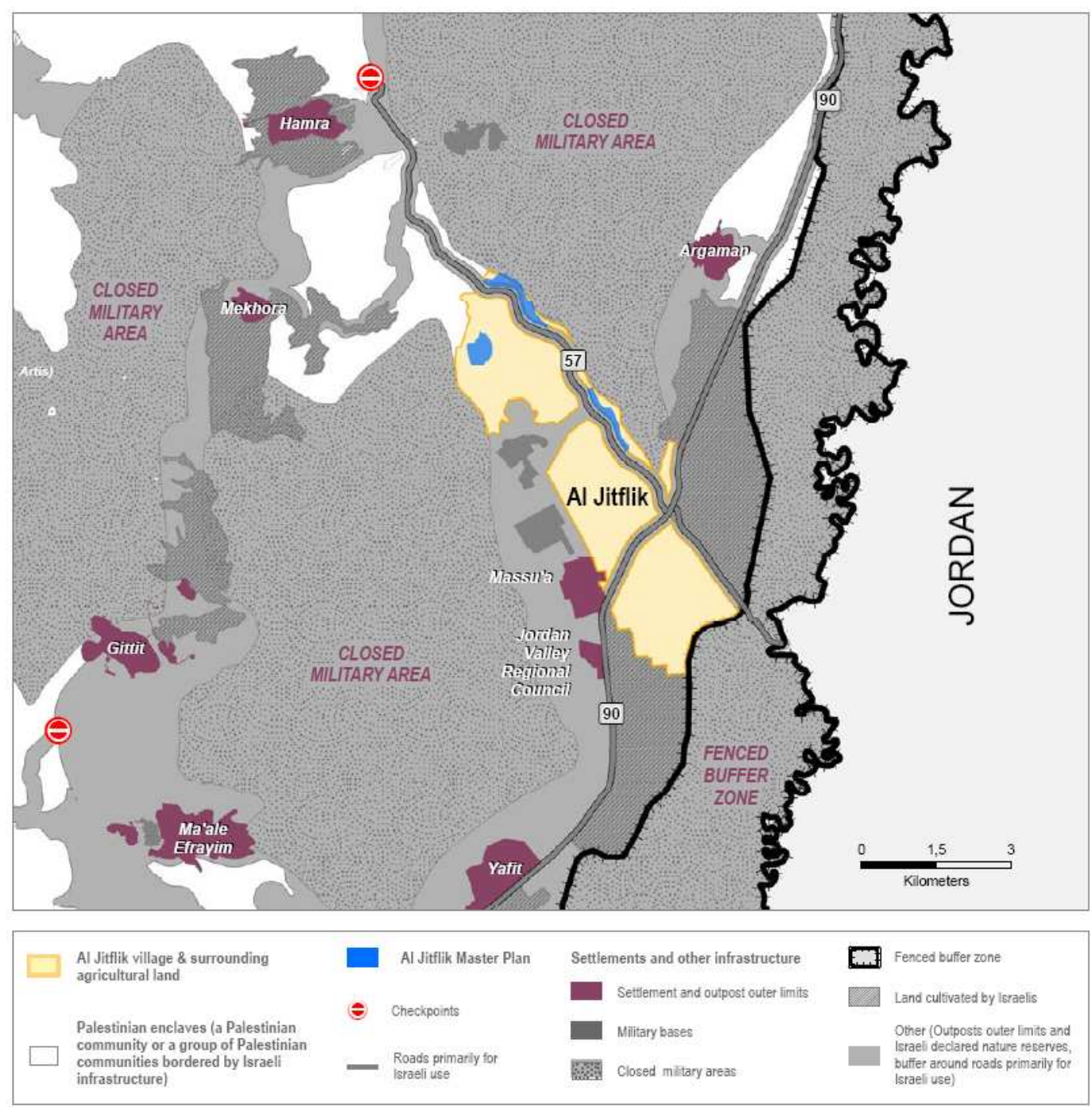




\section{REFERENCES}

Abu-Lughod, J. (1971). The Demographic Transformation of Palestine. In I. Abu-Loghod (Ed.) The Transformation of Palestine: Essays on the Origin and Development of the Arab-Israeli Conflict. (pp. 139-163). Evanston: Northwestern University Press.

Al Jazeera English. (2007, July 4). People \& Power - Golan Heights. Retrieved from http://youtube.com/watch?v=bbVuq5jJyWU

Al Jazeera English. (2008, September 26). Inside USA - The Other Hawaii. Retrieved from http://www.youtube.com/watch?v=gIq8x9vnLf4.

Arrighi, G. (2005, March/April). Hegemony Unravelling -1. New Left Review, 32, 23 - 80.

Arrighi, G. (2005, May). Hegemony Unravelling - 2. New Left Review, 33, 83 - 116.

Asadi, F. (1976). Some Geographic Elements in the Arab-Israeli Conflict. Journal of Palestine Studies, 6 (1), 79 - 91.

Associated Press. (2007, April 16). Facts and Figures. Retrieved from http://www.ap.org/pages/about/about.html

Aururi, N. (1989) Occupation: Israel over Palestine. Belmont, MA: AAUG Press.

Bahbah, B. (1982). The United States and Israel's Energy Security. Journal of Palestine Studies, $11(2), 113-131$.

Beinin, J. (1986). Private Capital in Israel. MERIP Middle East Report: Wealth and Power in the Middle East, 142 (35).

Biger, G. (1994). An Empire in the Holy Land: Historical Geography of the British Administration in Palestine - 1917-1929. New York and Jerusalem: St. Martin's Press and Magnes Press, The Hebrew University.

Blum, William. (2004). Killing Hope: US Military and C.I.A. Interventions Since World War II. Monroe, ME: Common Courage Press.

Brenner, N. (2001). The limits to scale? Methodological reflections on scalar structuration. Progress in Human Geography, 25 (4), 591 - 614. Retrieved from Academic Search Complete Database.

Brenner, N. (1998). Between fixity and motion: accumulation, territorial organization and the historical geography of spatial scales. Environment and Planning D: Society and Space, 16, 459 - 481. doi: 10.1068/d160459. 
Cockburn, A. and J. St. Clair, (Eds.) (2003) The Politics of Anti-Semitism. Petrolia and Oakland, CA: CounterPunch and AK Press.

Cox, K. (1998a). Spaces of dependence, spaces of engagement and the politics of scale, or: looking for local politics. Political Geography, 17 (1), 1 - 23. doi:10.1016/S09626298(97)00048-6.

Cox, K. (1998b). Representation and power in the politics of scale. Political Geography 17 (1), 41 - 44. doi:10.1016/S0962-6298(97)00051-6.

Chomsky, N. (1999). Fateful Triangle: The United States, Israel and the Palestinians. Cambridge, MA: South End Press.

Christison, B. (2008, February 7). Justice Unlikely in Near Future: Potholes Bigger Than Ever for Palestinians. CounterPunch. Retrieved from http://www.counterpunch.org/christison02072008.html

Cottam, R. (1971). The United States and Palestine. In I. Abu-Loghod (Ed.) The Transformation of Palestine: Essays on the Origin and Development of the Arab-Israeli Conflict. (pp. 387-411). Evanston: Northwestern University Press.

Darwish, M. You, as of now, are someone else! Poetry and Prose Selections. Retrieved 2 April 2009 from http://www.mahmouddarwish.com/english/Poetry.htm

Falah, G. (2007). The Politics of Doing Geography: 23 Days in the Hell of Israeli Detention. Environment and Planning D: Society and Space, 25, 587 - 593. doi: 10.1068/d2504ed.

Falah, G. (2005). The Geopolitics of 'Enclavisation' and the Demise of a Two-State Solution to the Israeli-Palestinian Conflict. Third World Quarterly, 26 (8), 1341 - 1372. Retrieved from Academic Search Complete Database.

Falah, G. (2003). Dynamics and Patterns of the Shrinking of Arab Lands in Palestine. Political Geography, 22 (2), 179 - 209. doi:10.1016/S0962-6298(02)00088-4.

Falah, G. (2001). Intifadat al-Aqsa and the Bloody Road to Palestinian Independence. Political Geography 20, (2), 135 - 137. doi:10.1016/S0962-6298(00)00071-8.

Falah, G. (1991). The Facts and Fictions of Judaization Policy and its Impact on the Majority Arab Population in Galilee. Political Geography Quarterly 10, (3), 297 - 316.

Falah, G. (1989). Israeli State Policy toward Bedouin Sedentarization in the Negev. Journal of Palestine Studies, 18 (2), 71 - 91.

Falah, G. (1989). The Judaization Policy in Galilee and its Impact on Local Arab Urbanization. Political Geography Quarterly, 8 (3), 229 - 253. 
Falah, G. and C. Flint. (2004). Geopolitical Spaces: The Dialectic of Public and Private Space in the Palestine-Israel Conflict. The Arab World Geographer, 7 (1-2), 117 - 134.

Ferguson, N. (2000). The House of Rothschild: The World's Banker 1849-1999. New York: Penguin Books.

Fisk, R. (2006). The Great War for Civilization: The Conquest of the Middle East. London: Harper Perennial.

Friedman, R. (1983). Israeli Censorship of the Palestinian Press. Journal of Palestine Studies, 13 (1), 93-101.

Gordon, N. (2008). Israel's Occupation. Berkeley and Los Angeles, CA: University of California Press.

Graham-Brown, S. (1989). The Economic Consequences of the Occupation. In N. Aruri (Ed.) Occupation: Israel over Palestine. (pp. 297-360). Belmont, MA: AAUG Press.

Halbrook, S. (1972) The Class Origins of Zionist Ideology. Journal of Palestine Studies, 2 (1), $86-110$.

Halperin, S. (1960). Ideology or Philanthrophy? The Politics of Zionist Fund-Raising. The Western Political Quarterly, 13 (4), 950 - 973. Retrieved from JSTOR Database.

Halpern, B. (1986). Brandeis Becomes a Zionist. Modern Judaism, 6 (3), 227 - 243. Retrieved from JSTOR Database.

Hanieh, A. (2003). From State-Led Growth to Globalization: The Evolution of Israeli Capitalism. Journal of Palestine Studies, 32 (4), 5 - 21.

Harrison, J. (2006). 'Accidents' and invisibilities: Scaled discourse and the naturalization of regulatory neglect in California's pesticide drift conflict. Political Geography, 25 (5), 506 - 529. doi:10.1016/j.polgeo.2006.02.003.

Harvey, D. (2006). Spaces of Global Capitalism: Towards a Theory of Uneven Geographical Development. Verso: New York.

Harvey, D. (2003). The New Imperialism. Oxford: Oxford University Press.

Heer, J. (2008, February 25). When Conservatives Loved the Palestinians. sans everything. Retrieved from http://sanseverything.wordpress.com/2008/02/25/when-conservatives-loved-thepalestinians/

Herod, A. (1997). Labor's spatial praxis and the geography of contract bargaining in the US east coast longshore industry, 1953-89. Political Geography, 16 (2), 145 - 170. doi:10.1016/S09626298(96)00048-0. 
Howitt, R. (1998). Scale as relation: musical metaphors of geographical scale. Area, 30 (1), 49 58. Retrieved from Academic Search Complete Database.

Howitt, R. (2000, December). Nests, Webs and Constructs: contested concepts of scale in political geography. Retrieved from http://www.es.mq.edu.au/ rhowitt/POLGEO.htm\#_ftnref3

Howitt, R. (2002). Scale and the other: Levinas and geography. Geoforum, 33, 299 - 313.

Ibrahim, T. On the Margins: Annual Review of Human Rights Violations of the Arab Palestinian Minority in Israel 2006. Retrieved 2007, December 6 from

http://www.arabhra.org/HraAdmin/UserImages/Files/YearlyReport2006FullVersionHighQuality English.pdf

Ingrams, D. (1972). Palestine Papers 1917-1922: Seeds of Conflict. London: John Murray.

Itayim, F. (1974). Arab Oil - The Political Dimension. Journal of Palestine Studies, 3 (2), 84 97.

Jadallah-Taschler, D. (2009, January 23/25). The Struggle of an Un-People. CounterPunch. Retrieved from http://www.counterpunch.org/taschler01232009.html

Jameson, F. (1980). Capitalism, Not Zionism, is the Problem. Journal of Palestine Studies, 9 (2), $154-157$.

Jayaprakash, N.D. (2002, June 28/30). The Palestinian Saga: Seething With Rage.

CounterPunch. Retrieved from http://www.counterpunch.org/jayaprakash0628.html

Jensen, R. (2007, May 25). What the Finkelstein Tenure Fight Tells Us About the State of Academia. CounterPunch. Retrieved from http://www.counterpunch.org/jensen05252007.html

Jones, K. (1998). Scale as epistemology. Political Geography, 17 (1), 25 - 28.

doi:10.1016/S0962-6298(97)00049-8.

Kelman, H. (1992). Acknowledging the Other's Nationhood: How to Create a Momentum for the Israeli-Palestinian Negotiations. Journal of Palestine Studies, 22 (1), 18 - 38.

Kerr, M. (1973). Nixon's Second Term: Policy Prospects in the Middle East. Journal of Palestine Studies, 2 (3), 14 - 29.

Khalidi, R. (1997). Palestinian Identity: The Construction of Modern National Consciousness. Columbia University Press: New York.

Khalidi, W. (1988). Plan Dalet: Master Plan for the Conquest of Palestine. Journal of Palestine Studies, 18 (1), 4 - 70.

Khan, Z. (1998). Palestine Documents. Pharos Media \& Publishing (P) Ltd: New Dehli. 
Khouri, R. (1980). Israel's Imperial Economics. Journal of Palestine Studies, 9 (2), 71 - 78.

Kissinger Memorandum. (1981). To Isolate the Palestinians. MERIP Reports, 96, 24 - 30.

Kochavi, A. (2001). Britain's Image Campaign against the Zionists. Journal of Contemporary History, 36 (2), 293 - 307. Retrieved from JSTOR Database.

Korn, D. (2004). Das Netz: Israels Lobby in Deutschland. Muenchen: FZ Verlag.

Lefebvre, H. (1991). Plan of the Present Work. The Production of Space. (pp. 1-67). Malden: Blackwell Publishing.

Leitner, H. (2004). The Politics of Scale and Networks of Spatial Connectivity: Transnational Interurban Networks and the Rescaling of Political Governance in Europe. In Sheppard and McMaster (Eds.) Scale \& Geographic Inquiry: Nature, Society, and Method. (pp. 236-255). Malden: Blackwell Publishing.

Lehn, W. (1974). The Jewish National Fund. Journal of Palestine Studies, 3 (4), 74 - 96.

Lendman, S. (2009, January 2). Blaming the Victims - The Dominant Media Vilify Hamas. Centre for Research on Globalization. Retrieved from http://www.globalresearch.ca/index.php?context=va\&aid=11579

Lendman, S. (2008, June 13). BBC's Pro-Israeli Bias. Centre for Research on Globalization. Retrieved from http://www.globalresearch.ca/index.php?context=va\&aid=9307

Lesch, Ann. (1989). Palestine: Land and People. In N. Aruri (Ed.) Occupation: Israel over Palestine. (pp. 49-75). Belmont, MA: AAUG Press.

Mallison, Jr., W. (1971). The Balfour Declaration: An Appraisal in International Law. In I. AbuLoghod (Ed.) The Transformation of Palestine: Essays on the Origin and Development of the Arab-Israeli Conflict. (pp. 61-111). Evanston: Northwestern University Press.

Marshall, M. (1995). Rethinking the Palestine Question: The Apartheid Paradigm. Journal of Palestine Studies, 25 (1), 15 - 22.

Marston, S. and N. Smith. (2001). States, scales and households: limits to scale thinking? A response to Brenner. Progress in Human Geography, 25 (4), 615 - 619. Retrieved from Academic Search Complete Database.

Mayhew, C. and M. Adams. (1975). Publish it not...The Middle East Cover-Up. London: Longman.

Menetrez, F. (2007, April 30). Dershowitz vs. Finkelstein: Who's Right and Who's Wrong? CounterPunch. Retrieved from http://www.counterpunch.org/menetrez04302007.html 
Merrett, C. (2001). Understanding Local Responses to Globalisation: The Production of Geographical Scale and Political Identity. National Identities, 3 (1), 69 - 87. Retrieved from Academic Search Complete Database.

Merrifield, A. (1993). The Struggle Over Place: Redeveloping American Can in Southeast Baltimore. Transactions, Institute of British Geographers, 18 (1), 102 - 121. Retrieved from JSTOR Database.

Merrifield, A. (1993). Place and Space: A Lefebvrian Reconciliation. Transactions, Institute of British Geographers, 18 (4), 516 - 531. Retrieved from JSTOR Database.

Metzer, J and O. Kaplan. (1985). Jointly but Severally: Arab-Jewish Dualism and Economic Growth in Mandatory Palestine. The Journal of Economic History, 45 (2), 327 - 345. Retrieved from JSTOR Database.

Miller, B. (1997). Political action and the geography of defense investment: geographical scale and the representation of the Massachusetts Miracle. Political Geography, 16 (2), 171 - 185. doi:10.1016/S0962-6298(96)00049-2.

Morris, B. (1995). Falsifying the Record: A Fresh Look at Zionist Documentation of 1948. Journal of Palestine Studies, 34 (3), 44 - 62.

Morris, B. (2001). Righteous Victims: A History of the Zionist-Arab Conflict, 1881-2001. New York: Vintage Books.

Moughrabi, F. (2001). The Politics of Palestinian Textbooks. Journal of Palestine Studies, 31 (1), 5 - 19.

Muralidharan, S. (2004, October 9). Israel: An Equal Partner in Occupation of Iraq. Economic and Political Weekly, 4517 - 4520.

Nakhleh, K. (2008, March 21). Al Nakba of 1948. Counterpunch. Retrieved from http://www.counterpunch.org/nakhleh03212008.html

Nakhleh, K. (2004). The Myth of Palestinian Development: Political Aid and Sustainable Deceit. Jerusalem: PASSIA.

Nakhleh, K. and C. Wright. (1983). After the Palestine-Israel War: Limits to U.S. and Israeli Policy. Belmont, MA: Institute of Arab Studies.

Neumann, M. (2005). The Case Against Israel. Petrolia and Oakland, CA: CounterPunch and AK Press.

Newman, D. (2002). The Geopolitics of Peacemaking in Israel-Palestine. Political Geography, 21 (5), 629 - 646. doi:10.1016/S0962-6298(02)00010-0. 
Ollman, B. (2003). Dance of the Dialectic: Steps in Marx's Method. Urbana/Chicago: University of Illinois Press.

Ovendale, R. (1980). The Palestine Policy of the British Labour Government 1947: The Decision to Withdraw. International Affairs, 56 (1), 73 - 93.

Pappe, I. (2007). The Ethnic Cleansing of Palestine. Oxford: Oneworld Publications Ltd.

Pappe, I. (2006a). The 1948 Ethnic Cleansing of Palestine. Journal of Palestine Studies, 36 (1), 6 $-20$.

Pappe, I. (2006b). A History of Modern Palestine. Cambridge: Cambridge University Press.

Pappe, I. (2000). Israel at a Crossroads between Civic Democracy and Jewish Zealotocracy. Journal of Palestine Studies, 29 (3), 33 - 44.

Petras, J. (2007) Rulers and Ruled in the US Empire: Bankers, Zionists, Militants. Atlanta, GA: Clarity Press.

Phillips, P. et al. A Study of Bias in the Associated Press. Project Censored. Retrieved April 2, 2009 from http://www.projectcensored.org/articles/story/a-study-of-bias-in-the-associated-press/

Pilger, J. (2007, July 26). How Truth Slips Down the Memory Hole. Antiwar.com. Retrieved from http://www.antiwar.com/pilger/?articleid=11349

Project for the New American Century. (1997, June 3). Statement of Principles. Retrieved from http://www.newamericancentury.org/statementofprinciples.htm

Reuveny, R. (2003). Fundamentalist Colonialism: The Geopolitics of Israel-Palestinian Conflict. Political Geography, 22 (4), 347 - 380. doi:10.1016/S0962-6298(02)00114-2.

Rissman, J. (2008, February 7). The Rewriting, Un-rewriting and Re-rewriting of History. Antiwar.com. Retrieved from http://www.antiwar.com/orig/rissman.php?articleid=14208

Roy, Sara. (1989). The Gaza-Strip: Critical Effects of the Occupation. In N. Aruri (Ed.) Occupation: Israel over Palestine. (pp. 249-296). Belmont, MA: AAUG Press.

Rubin, B. (1973). America's Mid-East Policy: A Marxist Perspective. Journal of Palestine Studies, 2 (3), 51 - 67.

Rubinstein, D. (2006, September 26). Why Recognize Israel? Haaretz. Retrieved from http://www.haaretz.com/hasen/spages/766429.html

Rudeneh, O. (1972). The Jewish Factor in US Politics. Journal of Palestine Studies, 1 (4), 92 107. 
Ruedy, J. (1971). Dynamics of Land Alienation. In I. Abu-Loghod (Ed.) The Transformation of Palestine: Essays on the Origin and Development of the Arab-Israeli Conflict. (pp. 119-138). Evanston: Northwestern University Press.

Ryan, S. (1974). Israeli Economic Policy in the Occupied Areas: Foundations of a New Imperialism. MERIP Middle East Report, 24, 3 - 28.

Sa'di, A. (1997). Modernization as an Explanatory Discourse of Zionist-Palestinian Relations. British Journal of Middle Eastern Studies, 24 (1), 25 - 48.

Said, E. (2000). The End of the Peace Process: Oslo and After. London: Granta Books.

Said, E. (1994). The Politics of Dispossession: The Struggle for Palestinian Self-Determination, 1969-1994. New York: Vintage Books.

Said, E. and C. Hitchens, Eds. (1988). Blaming the Victims: Spurious Scholarship and the Palestine Question. London: Verso.

Schechla, J. (2001). The Invisible People Come to Light: Israel's 'Internally Displaced' and the 'Unrecognized Villages'. Journal of Palestine Studies, 31 (1), 20 - 31.

Scholch, A. (1992). Britain in Palestine, 1838-1882: The Roots of the Balfour Policy. Journal of Palestine Studies, 22 (1), 39 - 56.

Selfa, L. (1998). Israel: The U.S. Watchdog. International Socialist Review, 4. Retrieved March 3, 2008 from http://www.isreview.org/issues/04/Israel_watchdog.shtml

Sharabi, H. (1973). Liberation or Settlement: The Dialectics of Palestinian Struggle. Journal of Palestine Studies, 2 (2), 33 - 48.

Shehadeh, R. (1989). The Changing Juridical Status of Palestinian Areas under Occupation. In N. Aruri (Ed.) Occupation: Israel over Palestine. (pp. 173-192). Belmont, MA: AAUG Press.

Shlaim, A. (2000). The Iron Wall: Israel and the Arab World. Allen Lane Penguin Press: London.

Smith, M. (1994). Can You Imagine? Transnational Migration and the Globalization of Grassroots Politics. Social Text, 39, 15 - 33. Retrieved from Academic Search Complete Database.

Smith, N. (1997). The Satanic Geographies of Globalization: Uneven Development in the 1990s. Public Culture, 19 (1), 169 - 189. 
Smith, N. (1995). Remaking Scale: Competition and Cooperation in Pre-national and Postnational Europe. In Heikki, Eskelinew, Folke and Snickars (Eds.) Competitive European Peripheries. (pp. 59-74). New York: Springer.

Smith, N. (1993). Homeless/global: scaling places. In Bird, B. Curtis, T. Putnam, G. Robertson and L. Tickner (Eds.) Mapping the futures: local cultures, global change. (pp. 87-119). London: Routledge.

Smith, N. (1992). Geography, Difference, and the Politics of Scale. In J. Doherty, E. Graham, and M. Malek (Eds.) Postmodernism and the Social Sciences. (pp. 57-59). London: Mackmillan.

Smith, N. (1984) Uneven Development: Nature, Capital and the Production of Space. Malden, MA: Blackwell Publishing.

Soffer, A. (1991). Israeli ‘Judaization’ Policy in Galilee and its Impact on Local Arab Urbanization. Political Geography Quarterly, 10 (3), 282 - 285.

Soja, E. (1980). The socio-spatial dialectic. Annals of the Association of American Geographers, 70 (2), 207 - 225. Retrieved from Academic Search Complete Database.

State of Israel. Basic Law: Israel Lands. Passed July 19, 1960. Retrieved March 25, 2009 from http://www.knesset.gov.il/laws/special/eng/basic13_eng.htm

Stein, L. (1961). The Balfour Declaration. New York: Schuster and Schuster.

Stephens, R. (1973). The Great Powers and the Middle East._Journal of Palestine Studies, 2 (4), $3-13$.

Stevens, R. (1973). Smuts and Weizmann. Journal of Palestine Studies, 3 (1), 35 - 39.

Stevens, R. (1971) Zionism as a Phase of Western Imperialism. In I. Abu-Loghod (Ed.) The Transformation of Palestine: Essays on the Origin and Development of the Arab-Israeli Conflict. (pp. 27-59). Evanston: Northwestern University Press.

Stork, J. and S. Rose. (1974). Zionism and American Jewry. Journal of Palestine Studies, 3 (3), $39-57$.

Swyngedouw, E. (1997). Neither Global nor Local: 'glocalization' and the politics of scale. In K. Cox (Ed.). Spaces of Globalization: reasserting the power of the local. (pp. 137-166). New York and London: Guildford Press.

Tamari, S. (1981). Building Other People's Homes: The Palestinian Peasant's Household and Work in Israel. Journal of Palestine Studies, 11 (1), 31 - 66. 
Terry, J. (1971). Israel's Policy toward the Arab States. In I. Abu-Loghod (Ed.) The Transformation of Palestine: Essays on the Origin and Development of the Arab-Israeli Conflict. (pp. 337-354). Evanston: Northwestern University Press.

The Electronic Intifada. (2008, April 24). Pro-Israel group's plan to rewrite history on Wikipedia. Centre for Research on Globalization. Retrieved from http://www.globalresearch.ca/index.php?context=va\&aid=8784

United Nations Office for the Coordination of Humanitarian Affairs (OCHA). (2007, August 30). The Humanitarian Impact on Palestinians of Israeli Settlements and other Infrastructure in the West Bank. Retrieved from

http://www.ochaopt.org//index.php?module=displaysection\&section_id=103\&static=0\&format= html\&period=50:YEAR

Ussishkin, A. (1973). The Jewish Colonization Association and a Rothschild in Palestine. Middle Eastern Studies, 9 (3), 347 - 357. Retrieved from JSTOR Database.

Verdery, R. (1971). Arab 'Disturbances' and the Commissions of Inquiry. In I. Abu-Loghod (Ed.) The Transformation of Palestine: Essays on the Origin and Development of the ArabIsraeli Conflict. (pp. 275-303). Evanston: Northwestern University Press.

Vitullo, A. (2003). People Tied to Place: Strengthening Cultural Identity in Hebron's Old City. Journal of Palestine Studies, 33 (1), 68 - 83.

Waterman, S. (1994). The Non-Jewish Vote in Israel in 1992. Political Geography, 13 (6), 540 558. doi:10.1016/0962-6298(94)90040-X

Weinstock, N. (1973). The Impact of Zionist Colonization on Palestinian Arab Society before 1948. Journal of Palestine Studies, 2 (2), 49 - 63.

Whitney, M. (2009, January 7). The Bloodbath in Gaza: Separating the truth from the hype.

Centre for Research on Globalization. Retrieved from

http://www.globalresearch.ca/index.php?context=va\&aid=11675

Wilson, E. (1973). The Palestine Papers, 1943-1947. Journal of Palestine Studies, 2 (4), 33 - 54.

Wolf, L. (1904). The Zionist Peril. The Jewish Quarterly Review, 17 (1), 1 - 25. Retrieved from JSTOR Database.

Wright, C. (1989). Facts and Fables: The Arab-Israeli Conflict. London: Kegan Paul International.

Yiftachel, O. and D. Rumley. (1991). On the Impact of Israel's Judaization Policy in the Galilee. Political Geography Quarterly, 10 (3), 286 - 296. 
Zu'bi, N. (1984). The Development of Capitalism in Palestine: The Expropriation of the Palestinian Direct Producers. Journal of Palestine Studies, 13 (4), 88 - 109.

Zureik, E. (2001). Constructing Palestine through Surveillance Practices. British Journal of Middle Eastern Studies, 28 (2), 205 - 227. 